\author{
UNIVERSIDADE DE SÃO PAULO \\ DEPARTAMENTO DE FILOSOFIA
}

BEATRIZ SORRENTINO MARQUES

\title{
$O$ agente apagado: o papel do agente nas explicações de ações
}

Versão corrigida

São Paulo

2016 
BEATRIZ SORRENTINO MARQUES

\title{
$O$ agente apagado: o papel do agente nas explicações de ações
}

\author{
Versão corrigida
}

Tese apresentada ao Departamento de Filosofia da Universidade de São Paulo para obtenção do título de Doutora em Filosofia

Área de Concentração: Filosofia da Mente

Orientador: Prof. Dr. Osvaldo Frota Pessoa Jr.

São Paulo

2016 
Autorizo a reprodução e divulgação total ou parcial deste trabalho, por qualquer meio convencional ou eletrônico, para fins de estudo e pesquisa, desde que citada a fonte.

Catalogação na Publicação

Serviço de Biblioteca e Documentação

Faculdade de Filosofia, Letras e Ciências Humanas da Universidade de São Paulo

M357a

Marques, Beatriz Sorrentino

O agente apagado: o papel do agente nas

explicações de ações / Beatriz Sorrentino Marques

orientador Osvaldo Frota Pessoa Jr.. - São Paulo, 2015 .

$136 \mathrm{f}$.

Tese (Doutorado)- Faculdade de Filosofia, Letras

e Ciências Humanas da Universidade de São Paulo.

Departamento de Filosofia. Área de concentração:

Filosofia.

1. Filosofia. 2. Filosofia da Mente. 3. Filosofia da Ação. I. Pessoa Jr., Osvaldo Frota, orient. II. Título. 
Nome: MARQUES, Beatriz Sorrentino

Título: $\mathrm{O}$ agente apagado: $\mathrm{O}$ papel do agente nas explicações de ações

Tese apresentada ao Departamento de Filosofia da Universidade de São Paulo para obtenção do título de Doutora em Filosofia

Aprovado em:

Banca Examinadora

Prof. Dr. Instituição:

Julgamento: Assinatura:

Prof. Dr. Instituição:

Julgamento: Assinatura:

Prof. Dr. Instituição:

Julgamento: Assinatura:

Prof. Dr. Instituição:

Julgamento: Assinatura:

Prof. Dr. Instituição:

Julgamento: Assinatura: 
A todos aqueles que minhas decisões me levaram para longe. 


\section{AGRADECIMENTOS}

Agradeço o apoio financeiro e institucional da Fundação de Amparo à Pesquisa do Estado de São Paulo (FAPESP), processo no 2011/21030-0, e processo BEPE, n 2014/02558-1.

Ao Prof. Dr. Osvaldo Frota Pessoa Jr. pela sua orientação, conselhos e sugestões ao longo da produção dessa tese. Igualmente, ao Prof. Dr. Alfred R. Mele por sua supervisão do projeto BEPE (FAPESP) que em muito auxiliou o desenvolvimento da presente pesquisa.

À Josh Turkewitz, Sam Sims, Raquel Krempel, Eduarda Calado, Rogério Tesa, Robyn R. Waller e Milena Souza. Amigos que contribuíram com seu apoio, revisão de capítulos e discussão de diversas partes dessa tese.

Finalmente, agradeço à minha família, Alberto, Gianna, Daniel e Olga, pelo apoio incondicional durante o doutorado. E aos amigos, que se fizeram sempre presentes e encorajadores: Márcio Correa, Grace Bungenstab, Olívia Evangelista, Georgia Rae Rainer, Sara Kolms, Josh Turkewitz e Wendy Bungenstab. 
«La doctrine que je vous présente est justement à l'opposé du quiétisme, puisqu'elle déclare: il n'y a de réalité que dans l'action; elle va plus loin d'ailleurs, puisqu'elle ajoute: l'homme n'est rien d'autre que son projet, il n'existe que dans la mesure où il se réalise, il n'est donc rien d'autre que l'ensemble de ses actes, rien d'autre que sa vie. »

Sartre, L'Existentialism est un humanism, 1946 


\section{RESUMO}

\section{MARQUES, B. S. O agente apagado: O papel do agente nas explicações de ações. 2016.}

Tese (Doutorado). Departamento de Filosofia, Universidade de São Paulo, São Paulo, 2016.

O problema do Desaparecimento do Agente é uma objeção que tem assolado a Teoria Causal da Ação ao longo da maior parte da sua história contemporânea, mesmo tendo essa teoria se tornado a ortodoxia da explicação de ações. A objeção questiona qual seria o papel do agente, se é que ele teria algum, se apenas seus estados mentais parecem ter um papel causal relevante na produção de ações, como afirma a Teoria Causal da Ação. Essa questão permanece sem resposta satisfatória e recentemente tem originado até mesmo versões recentes do problema do Desaparecimento do Agente que levam o Livre Arbítrio e a consciência em consideração como sendo centrais para o debate. Assim, aceitar a Teoria Causal da Ação requer lidar com o problema em questão. Esse debate se beneficiará do diálogo com a psicologia e a neurociência e, com base nessa troca, eu argumentarei que o problema do Desaparecimento do Agente surge de uma concepção equivocada do que seria um agente humano e qual seria o seu papel na produção de suas ações. Isso se torna claro quando percebemos que essa concepção não corresponde ao nosso conhecimento científico atual a respeito da produção das ações humanas. Aceito isso, eu proponho então uma concepção diferente de agentes que não permite o surgimento do problema do Desaparecimento do Agente.

Palavras-chave: agente, consciência, intenções, desaparecimento do agente, controle. 


\begin{abstract}
MARQUES, B. S. The disappearing agente: the role of the agente in the explanation of actions. 2016. PhD Thesis. Departamento de Filosofia, Universidade de São Paulo, São Paulo, 2016.

The problem of the Disappearing Agent is an objection that has haunted the Causal Theory of Action for most of its contemporary history, even if this theory has become the orthodoxy of action explanation. The objection questions what role, if any, is reserved for the agent, if only her mental states seem to have a relevant causal role in the production of action, as the Causal Theory of Action would have it. This question remains unsatisfactorily answered, and has even originated recent versions of the Disappearing Agent issue, which take Free Will and consciousness as being at the center of the debate. Therefore, acceptance of the Causal Theory of Action requires dealing with such problem. This debate will benefit from a dialog with psychology and neuroscience, and based on this exchange I will argue that the issue of the Disappearing Agent springs from a misguided conception of what is a human agent and what is the agent's role in the production of her action. This becomes clear when we realize that this conception does not correspond to our current scientific knowledge about the production of human action. Accepting this, I then propose a different conception of agents that does not allow for the Disappearing Agent problem to rise.
\end{abstract}

Keywords: agent, consciousness, intentions, agent causation, control. 


\title{
LISTA DE ABREVIATURAS
}

\author{
AI Agente Ilusório \\ CA Causalidade do Agente (Teoria) \\ DA Desaparecimento do Agente \\ TCA Teoria Causal da Ação \\ TCMA Teoria da Causalidade Mental Aparente
}




\section{SUMÁRIO}

INTRODUÇÃO

Capítulo I - Teoria da Causalidade do Agente vs. Teoria Causal da Ação.............................. 16

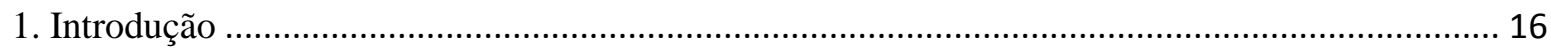

2. Teoria da Causalidade do Agente: uma visão geral ………....................................................... 17

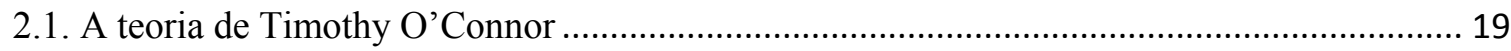

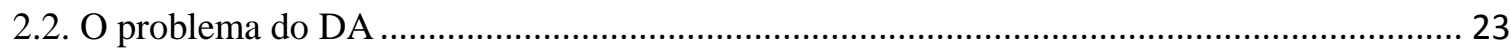

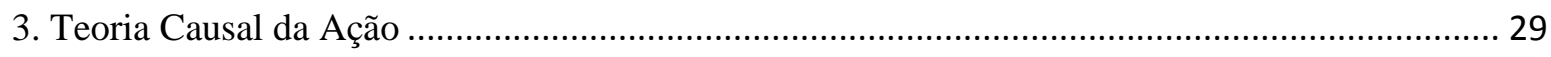

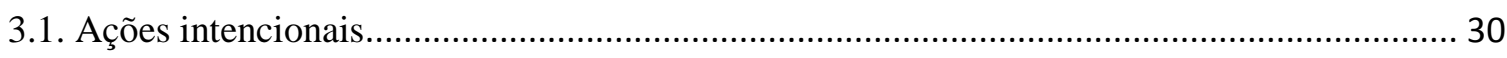

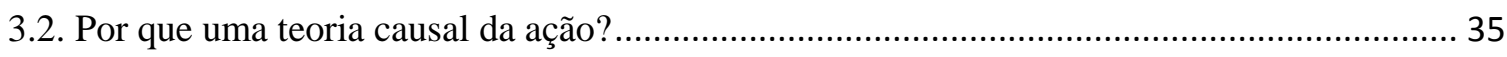

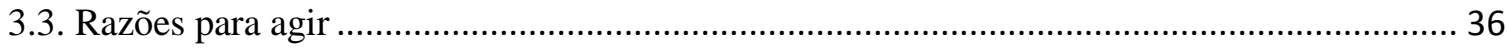

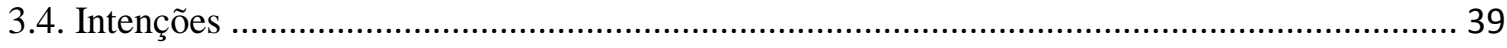

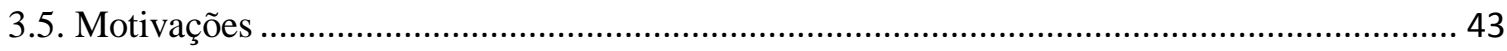

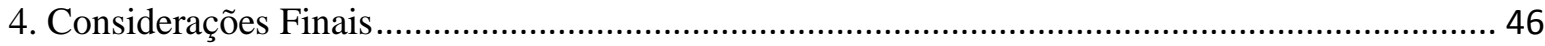

Capítulo II - Oposição à Teoria Casual da Ação: Daniel Wegner e a Ilusão da Intenção ......... 47

1. O problema da vontade consciente segundo Daniel Wegner ..................................................... 47

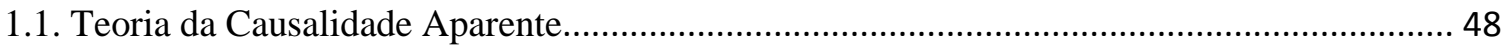



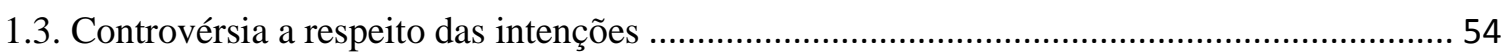



2.1. Paralelo: zumbi interno e desaparecimento do agente ...................................................... 58

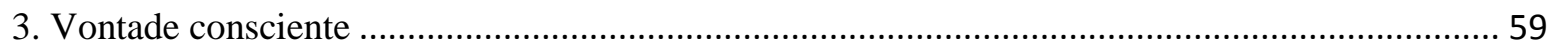

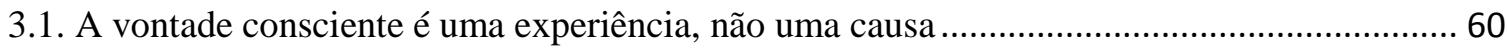

3.2. EPC é uma experiência confiável que não corresponde a uma causa de ação ......................... 62

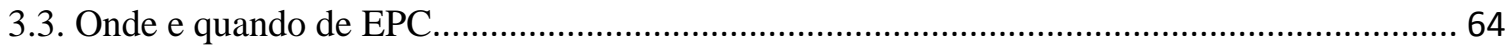

4. RPs não são preparação da ação: a estimativa de tempo da EPC está errada ............................... 68

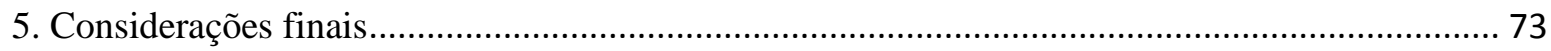

Capítulo III - A Consciência das Intenções e o Conceito de Agentes ..................................... 74

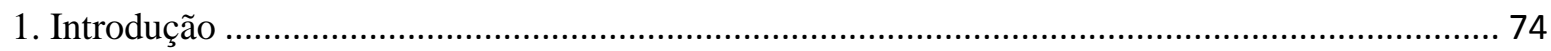

2. A falta de um papel para a consciência das intenções na teoria de Wegner................................. 75 
3. Concebendo intenções como sendo estados mentais conscientes .............................................. 78

4. O problema: como intenções podem ser tanto conscientes quanto não-conscientes? ..................... 79

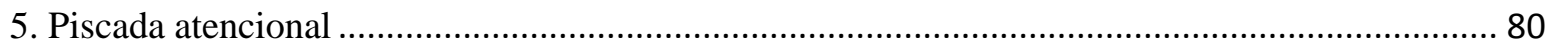

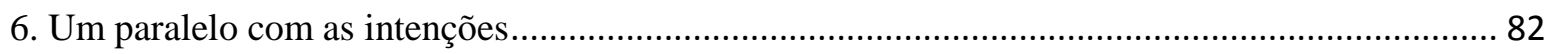



8. Agentes e seu papel na produção de ações ................................................................................. 91

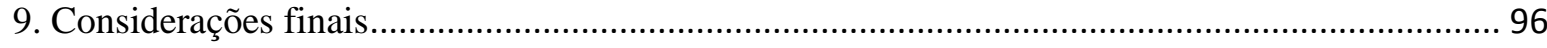

Capítulo IV - A Noção de Agência na Teoria da Causalidade do Agente................................98

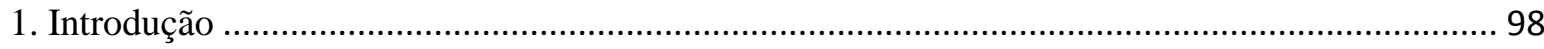

2. Discussão preliminar: a concepção de agente na CA ................................................................. 99

3. Lowe: o agente como sendo uma substância distinta................................................................ 106

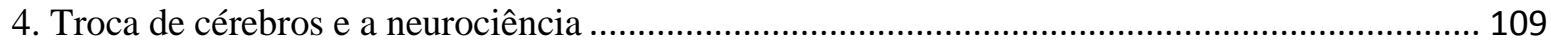

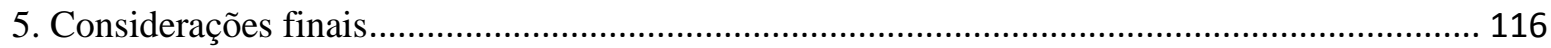

Capítulo V - Uma Nova Concepção de Agentes .................................................................... 117

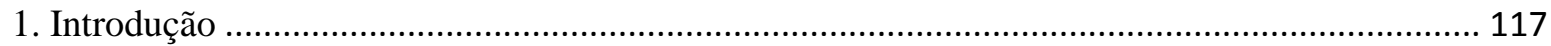

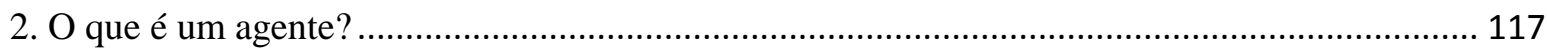

3. Agentes, estados mentais e seus realizadores físicos ........................................................... 119

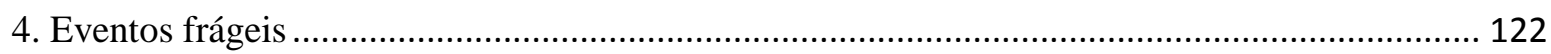

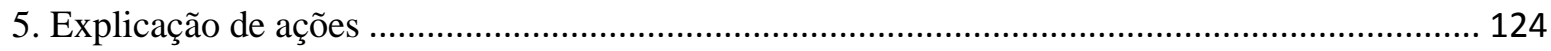

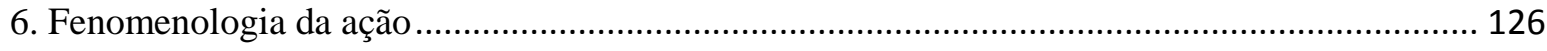

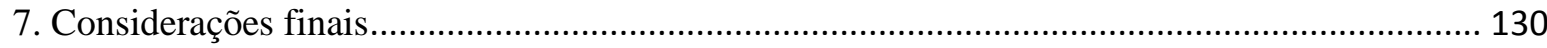

CONCLUSÃO

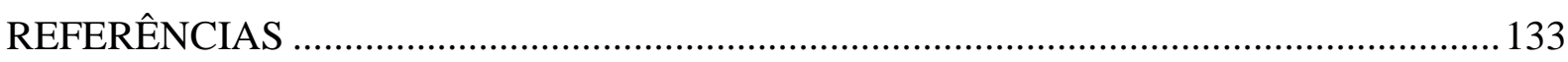




\section{INTRODUÇÃO}

Eu não diria que sou o tipo de pessoa que tem medo de animais. Ao contrário, eu gosto de animais. Normalmente insetos não são do tipo de seres que eu gostaria de ter em minha casa, mas eu não costumo sentir pavor quando descubro uma dessas criaturas escondida num local inesperado. Há, no entanto, um ser cuja visão me causa uma angústia profunda: a lagartixa. Quando encontro uma visitando, sem avisar, o meu apartamento, a minha primeira reação é de horror! E só depois minhas reflexões se alinham ao aspecto prático do problema: como me livrarei desse inquilino indesejado?

Hoje cedo, quando acordei, me deparei com uma lagartixa no caminho para a cozinha! Não me pareceu que ela percebeu que não era bem-vinda, nem que adiantaria muito se eu a convidasse a se retirar. Então, depois que retomei o domínio de mim me pus a deliberar como eu faria para que ela deixasse o apartamento.

A primeira estratégia que me ocorreu seria delegar o problema para outra pessoa, mas, infelizmente, não havia ninguém mais em casa. Então, percebi que, se eu queria ela fora de casa, eu teria que tirar a lagartixa eu mesma (jamais teria pensado em exterminá-la, pois a ideia me causa ainda mais horror do que a convivência com esse ser pouco cativante). Como eu acredito que esse animal se assusta facilmente e se move rapidamente, eu imaginei que seria melhor assustá-lo de maneira que ele subisse numa pá, assim eu poderia levar a pá para fora e fazê-lo descer lá. A pá manteria alguma distância entre nós para que eu pudesse soltá-la caso a lagartixa começasse a se mover rapidamente em direção à minha mão (que estaria segurando a pá).

Uma vez deliberado o plano, eu estava convencida de que era o melhor a se fazer. Eu estava resolvida a executá-lo. Respirei fundo, peguei a pá, fiz a lagartixa subir nela e a levei até a janela. A lagartixa desceu na parede externa e eu pude fechar a janela, mantendo-a do lado de fora. Uma maneira certamente pouco polida de tratar uma visita, mas eficiente para a minha tranquilidade. A operação foi bem sucedida e eu pude começar o meu dia.

O funcionamento interno humano sempre foi uma fonte de fascínio para pensadores e leigos ao longo história da humanidade. E durante longo tempo esse funcionamento pareceu ser tão misterioso e impossível de desvendar que alguns o atribuíram a fatores místicos ou divinos, apenas explicável por meio de mitos ou religião. Já outros tentaram formular teorias para explicar como funcionaria um ser humano. Resultam dessa curiosidade e ímpeto 
exploratório diversas observações do comportamento, autópsias, experimentos e teorias, dentre elas as teorias que visam explicar as ações humanas. Enquanto que a psicologia se ocupa de alguns aspectos do estudo das ações, a filosofia desde os gregos se pergunta como as ações humanas seriam produzidas. Além dessa, outras dúvidas fazem parte das questões filosóficas sobre ações: como aquilo que se pensa poderia governar o corpo (como parece ser o caso)? A experiência que temos de produzir nossas ações corresponde a como ações são de fato produzidas? Qual a diferença entre algo que o agente faz e aquilo que lhe acontece? Ações teriam causas? Quais seriam elas? As ações humanas seriam livres? Qual o critério para se atribuir responsabilidade moral/legal por uma ação?

Há uma série de ações descritas na estória acima sobre a lagartixa invasora; por exemplo, o trecho em que eu busco uma pá para me auxiliar na árdua tarefa de remover a invasora de dentro de casa. Poder-se-ia explicar a ação lembrando que eu tinha o desejo de remover a lagartixa e a crença de que colocá-la em uma pá seria a melhor maneira de fazê-lo, de modo que a conjunção desses estados mentais causou a minha ação de buscar a pá. Ou talvez fosse possível pensar que o meu plano de remoção da intrusa somado ao desejo de removê-la contribuíram para que eu adquirisse a intenção de buscar a pá (ou de executar o plano por completo), e a intenção causou a ação. Ou ainda, seria possível especular que certas atividades cerebrais no meu córtex e área motora (os realizadores físicos dos estados mentais citados anteriormente) causaram a minha ação de buscar a pá.

No primeiro momento, é difícil perceber porque deveríamos preferir uma explicação à outra, o que traz preocupações quanto a como poderíamos decidir entre uma explicação de ação e outra. A partir daí teorias distintas podem ser desenvolvidas para competir pela melhor explicação. Contudo, há ainda outra preocupação: e se as explicações propostas não forem capazes de englobar, e assim explicar, todos os aspectos relevantes das ações humanas? Não estaria faltando nelas algo que caracterizaria essas ações: o agente?

Essa preocupação seria a de que, ao olhar para eventos internos do agente para explicar suas ações, as explicações de ação estariam excluindo aquilo que caracteriza as ações humanas: o agente que tem o poder de iniciar a ação que ele escolhe, quando ele escolhe fazêlo. Isso seria justamente o fundamento da liberdade humana e aquilo que possibilita sua responsabilidade moral. Poderia até haver quem dissesse que nós temos uma experiência fenomênica de produzir nossas ações, e que essa seria uma evidência de que algo está faltando nas explicações de ações sugeridas acima.

O problema da exclusão do agente por teorias causais da ação é chamado de problema do desaparecimento do agente, exclusão do agente, alienação do agente, ou falta do agente, na 
literatura filosófica sobre ações. Esse será o tema e a preocupação principal dessa investigação. Uma imagem de David Velleman (1992) ajuda a ilustrar o problema; não se pode aceitar uma explicação de ações na qual o agente seria como uma arena onde seus estados mentais produzem suas ações, enquanto que o agente não faria coisa alguma.

Assim, surge um desafio para as teorias que visam explicar ações, que seria o desafio de propor uma explicação sem excluir o agente. E com o desafio surge também a dúvida quanto à possibilidade de propor uma explicação para ações que esteja de acordo com o naturalismo e com aquilo que a ciência diz atualmente, ao mesmo tempo em que essa explicação guardaria o agente da ação concedendo-lhe sua devida relevância.

A resposta para essa dúvida é “sim”. Sim, é possível explicar ações sem que algo fundamentalmente relevante na sua produção, como o agente, seja excluído. A presente investigação mostrará como isso é possível propondo um diálogo com a psicologia e a neurociência, áreas afins da filosofia da mente. Será defendido que o problema em questão surge de uma concepção equivocada do que é um agente humano e qual o seu papel na produção de ações, que não corresponde ao nosso conhecimento científico atualmente a respeito dessa produção.

Ademais, será argumentado que a produção das ações humanas é singular e particular de cada agente, graças à sua genética, ambiente e experiências (dentre outros fatores) e que a história causal da produção de cada ação estaria, assim, conectada ao seu agente de modo que os estados mentais (ou seus realizadores fisiológicos) não ocorreriam no agente como em uma arena. Pois, os estados mentais envolvidos na produção da ação seriam característicos do agente (da sua estrutura cerebral) e a história causal de cada ação remontaria ao seu agente não por acaso.

Mas não devemos nos adiantar. Para defender essa tese será preciso uma ampla investigação pela qual serão trilhados os argumentos em seu favor. No Capítulo I será apresentado o contexto teórico no qual surge o chamado problema do desaparecimento do agente. Esse contexto é a competição entre duas teorias que visam explicar ações, a Causalidade do Agente (CA) e a Teoria Causal da Ação (TCA). Assim, será possível explicar claramente do que se trata o problema em questão.

No Capítulo II uma teoria recente que traz uma versão atual do problema será apresentada, a teoria de Daniel Wegner (2002). A teoria de Wegner e as questões que ela coloca para teorias que visam explicar ações ajudarão na compreensão das preocupações que estão por traz do problema do desaparecimento do agente. 
O Capítulo III visa responder a uma questão que provém da discussão a respeito da teoria de Wegner: se teorias causais da ação respondem ao argumento de Wegner, de que automatismos mostram que a vontade consciente não participa da produção causal de ações, com a proposta de que ações produzidas conscientemente e inconscientemente são produzidas da mesma maneira, então qual seria o papel da consciência nessa produção? Igualmente, serão examinados quais são os pressupostos da noção de que agentes teriam que produzir conscientemente suas ações para não estarem excluídos dessa produção.

No Capítulo IV algumas teorias da Causalidade do Agente serão discutidas com o propósito de mostrar que sua concepção de agente está equivocada e isso gera expectativas irreais a respeito do papel do agente na produção de suas ações. Afinal, essa concepção não está de acordo com o conhecimento científico atual dessa produção. Uma vez que fica claro que a concepção de agentes precisa ser revisada, também fica claro que o problema do desaparecimento do agente deve passar pela mesma revisão.

Finalmente, o Capítulo V propõe uma nova concepção de agente, que esteja mais de acordo com as novas descobertas da neurociência. Essa revisão ajuda a mostrar a relação do agente com a produção de sua ação e como essa efetivamente depende dele. Assim, ficará claro que o agente não desaparece se consideramos essa nova concepção de agente. 


\section{Capítulo I - Teoria da Causalidade do Agente vs. Teoria Causal da Ação}

\section{Introdução}

A ação humana tem sido um interesse da filosofia desde a antiguidade. Uma das questões chave para as teorias da ação atualmente é fornecer uma explicação satisfatória sobre como uma ação é produzida pelo agente. Nesse contexto, principalmente durante o século XX e até hoje, duas teorias da ação foram desenvolvidas. Uma é a Teoria Causal da Ação (TCA), à qual o nome de Donald Davidson está associado, e a outra teoria é a Causalidade do Agente (CA), em relação à qual os nomes de Roderick Chisholm e Timothy O'Connor se destacam, dentre outros. Ambas as teorias têm grande expressão, embora a TCA tenha se tornado a mais hegemônica na explicação das ações.

A TCA visa explicar ações mostrando a relação causal existente entre estados mentais do agente relevantes para ação — como desejos, crenças e intenções-e a ação. Assim, estados mentais relevantes que antecedem a ação causariam a mesma, sendo assim necessários para sua produção. Entretanto, as TCA são muitas, de modo que a concepção da explicação das ações pode variar de acordo com a teoria de cada filósofo; por exemplo, há diferentes formas de se pensar como os estados mentais do agente estão relacionados às suas atividades cerebrais e se esses causam ações de forma determinista ou não.

Já a CA propõe outro tipo de explicação para ações, muitas vezes com base no que é considerado um poder causal sui generis do agente (CLARKE, 2010). Segundo essa teoria, o agente não necessitaria de estados mentais intermediários para causar suas ações; a produção da ação ocorreria quando o agente diretamente fizesse a ação ocorrer, espontaneamente. Embora mantenha essas linhas gerais, esse tipo de explicação também sofre variações de acordo com como cada autor a concebe (CLARKE, 2010); alguns autores aceitam que os desejos do agente o influenciam a agir, enquanto outros rejeitam essa ideia.

$\mathrm{Da}$ discussão promovida pelas duas teorias citadas acima surge o problema do Desaparecimento do Agente (DA). As duas diferentes teorias que propõem explicações para ações competem entre si; e cada uma apresenta críticas à outra, além de tentar desenvolver 
respostas às suas próprias dificuldades. O DA é uma objeção que a CA e teorias alternativas que visam explicar ações ${ }^{1}$ colocam para a TCA. Portanto, para compreender o problema do DA é preciso antes compreender em qual contexto esse problema surge (o que será discutido ao longo desse trabalho); i.e., compreender a explicação das ações proposta pela TCA.

Este capítulo será dividido em duas seções, a 2 visa o esclarecimento do que é a CA e a 3 do que é a TCA. Dentro da seção 2, a primeira parte será uma breve revisão de teorias historicamente relevantes e a exposição da teoria de Timothy O'Connor (seção 2.1), que será tomado como um exemplo atual da CA. E a seção 2.2 apresenta, dentro do contexto da CA, o problema do DA a partir do ponto de vista de diversos autores, como Thomas Nagel, E. J. Lowe, Roderick Chisholm e David Velleman, dentre outros, tendo em vista elucidar a profundidade do problema e expor brevemente o ponto de vista de alguns teóricos a seu respeito.

\section{Teoria da Causalidade do Agente: uma visão geral}

Timothy O’Connor (2000) revisou algumas teorias de CA que ganharam notoriedade, antes de apresentar seu próprio ponto de vista. O autor tem a intenção de evitar problemas que ele acredita que essas teorias incorreram em suas propostas. Assim, ao construir sua própria explicação de ações, ele discute outras, observando suas falhas. A teoria de O’Connor visa conciliar alguns aspectos da Teoria Causal da Ação, como a influência de razões de agir sobre o agente, para evitar problemas comuns às teorias da Causalidade do Agente.

Por isso, a teoria de O’Connor $(1995,2000,2013)$ será tomada como exemplo de CA, o que ajudará a compreender que tipo de explicação de ação propõe esse tipo de teoria e qual o tipo de relação causal envolvida nelas. Porém, esse não é o modelo único de teorias da CA, pois as mesmas podem propor até mesmo teorias em que não haveria uma relação causal entre o agente e sua ação (LOWE 2008). Essa breve apresentação da CA ajudará a compreender o contexto e concepções envolvidos no surgimento do problema do DA.

\footnotetext{
${ }^{1}$ Uma teoria alternativa para a explicação de ações que não será explorada aqui é a teoria de que razões para agir explicariam a ação do agente, porém, sem causar a ação. Thomas Nagel (1986), Abraham Melden (1991) e Elisabeth Anscombe (1957) são associados a essa teoria que perdeu popularidade depois do famoso desafio de Davidson (vide a seção 3 desse capítulo). Como será visto na seção 2.2., esses teóricos também fazem parte do coro da objeção do DA contra a TCA.
} 
De acordo com certo tipo de CA, o agente seria a causa da sua volição [volition], sendo a volição um estado que antecede a ação e que o agente determinaria por meio de sua vontade [to will it]; assim, a determinação da volição seria um efeito que teria uma causa: a vontade. Esse tipo de teoria O’Connor associa ao filósofo Thomas Reid. Nesse sentido, compreende-se que ser um agente é ser uma causa (eficiente), o que significaria "exercer o poder de diretamente causar uma volição desencadeadora-de-ação" (O'CONNOR, 2000, p. 45). Nesse sentido, a causalidade seria um termo reservado para agentes e não para objetos.

Entretanto, a determinação da vontade não deve ser compreendida como uma ação ela mesma; nesse sentido, o exercício desse poder não é um evento prévio à ação, mas a relação causal entre o agente e sua volição. O’Connor, porém, questiona se a mudança no estado das coisas originada pelo agente, no caso o surgimento de uma volição, não seria um evento. $\mathrm{O}$ autor defende que essa é uma interpretação possível desse tipo de teoria, o que consistiria em um problema para a teoria, pois se o agente causar uma ação for um evento que antecede sua ação, passa a ser necessário explicar esse evento antecedente, a vontade, antes de explicar a ação.

Há também um tipo de CA de acordo com a qual a causalidade do agente é um conceito primitivo e, portanto, irredutível. Assim, ações seriam movimentos corporais causados pelo agente, incluindo os eventos cerebrais envolvidos. O’Connor associa essa teoria a Richard Taylor. Não haveria, assim, a intermediação de volições, decisões, nem de qualquer evento mental como causa da ação; o agente diretamente causaria os eventos neurofisiológicos que levam à ação. Contudo, O’Connor considera pouco claro como isso ocorreria.

Chisholm $(1964,1976)$ desenvolveu longamente sua teoria da Causalidade do Agente, de acordo com a qual esse seria um tipo de causalidade diferente e que requereria intencionalidade. As volições são rejeitadas nessa teoria, de modo que o agente iniciaria diretamente sua ação, ao mesmo tempo em que tem a intenção de agir. De acordo com essa perspectiva, o agente age quando faz $x$ acontecer em vista de fazer $y$ acontecer, o que requer que o agente seja inteligente e tenha um propósito.

Este, no entanto, é um ponto de discordância para O'Connor, pois o autor defende que essa formulação de Chisholm permite que haja um evento prévio à causalidade do agente, que a causaria, dado que o agente faz $x$ em vista de fazer $y$. Contudo, de acordo com O'Connor, quando um agente causa sua ação, essa causação direta não pode ser causada por um evento prévio. Os eventos causados pelo agente são intrinsecamente ações, visto que são "o exercício 
do controle sobre o próprio comportamento" (O’CONNOR, 2000, p. 59). Assim, não é necessário que nenhum exercício prévio a esse seja empreendido.

Assim, de acordo com essa revisão, O’Connor considera que três pontos importantes das CA devem ser enfatizados: (1) a causalidade do agente é um tipo especial de evento; (2) esse evento não é causado por outro anterior a ele; (3) essa causalidade é um exercício do controle do agente sobre o seu comportamento.

O’Connor, contudo, admite que algumas questões ainda precisam ser resolvidas e que essas não foram adequadamente respondidas pelos autores anteriores. São elas: (1) que tipo de causalidade seria a causalidade do agente? (2) Como a estrutura causal padrão influenciaria e limitaria a causalidade do agente? (3) Como seria possível conciliar esse tipo de causalidade com uma descrição científica do mundo?

\subsection{A teoria de Timothy O'Connor}

A CA é uma teoria tradicional sobre a produção de ações, que se opõe à TCA. Ao passo que a última explica ações com base em eventos mentais que a causariam, a CA propõe "outra espécie do gênero causal, envolvendo a atividade característica de agentes intencionais" (O’CONNOR, 2000, p. 72). O’Connor, porém, acredita que só este poder não seria o suficiente para explicar ações e dependeria das circunstâncias e dos motivos do agente.

A teoria tenta explicar a causalidade entre eventos aceitando a existência de particulares poderosos, ${ }^{2}$ cujo poder é derivado da sua estrutura subjacente, como sua estrutura física, química ou biológica. Quando tal particular se encontra em circunstâncias apropriadas, ele manifesta seu poder de forma observável, ou por estimulação de mecanismos latentes para agir ou removendo inibições à ação. Alguns objetos têm efeitos característicos quando se encontram em determinadas circunstâncias, como o gelo que derrete no calor. De acordo com essa teoria, o poder causal envolvido nesses casos se deve a um conjunto de propriedades da substância.

Haveria, porém, outro tipo de causalidade, aquela característica de agentes intencionais. Os últimos são concebidos como sendo particulares que livre e diretamente

\footnotetext{
${ }^{2}$ O’Connor atribui esse conceito a R. Harré e E.H. Madden em seu livro "Causal Power: A Theory of Natural Necessity" de 1975. O autor, embora não concorde com a teoria explicitada no livro, toma emprestada a noção de particulares poderosos [powerful particulars].
} 
fazem acontecer um efeito, produzindo estados executivos imediatos de intenção de agir. Para tanto, o autor considera necessário que o agente tenha a capacidade de representar possíveis cursos de ação e ter desejos e crenças relativos aos mesmos.

Paralelamente às causas de eventos, as capacidades distintas da causalidade do agente ('poderes ativos') são fundamentadas numa propriedade ou conjunto de propriedades. Então, qualquer agente que tenha as propriedades internas relevantes terá diretamente o poder de causar qualquer uma de uma gama de estados de intenções delimitados por circunstâncias internas e externas. (O'CONNOR, 2000, p. 72).

O poder ativo do agente estaria fundamentado sobre suas propriedades intrínsecas de forma paralela aos particulares poderosos envolvidos na causalidade de eventos. Por meio desse, o agente poderia causar direta e livremente seus estados intencionais; nesse sentido, a intenção produzida não seria um mero efeito das circunstâncias. É relevante ressaltar que O’Connor considera importante o agente estar consciente, ou pelo menos ciente, do que ele está fazendo, para que ele possa exercer esse poder.

Nesse tipo de processo causal, as circunstâncias tornam possível que essas propriedades do agente, que permitem sua escolha, se manifestem. Nesses casos, o agente pode exercer seu poder causal livremente, que não é redutível a poderes dos seus constituintes microfísicos. Assim, O’Connor defende que pessoas são entidades biológicas com propriedades e capacidades mentais irredutíveis. ${ }^{3}$ Essa teoria, portanto, nega que ações sejam causalmente determinadas por qualquer outra força além do agente.

A visão dominante das teorias da ação, a TCA, atualmente defende que razões explicam ações porque razões para agir causariam a ação em questão (DAVIDSON, 1980, p. 09). Afinal, explicar uma ação exige mais do que simplesmente dizer que o agente decidiu agir; é importante dizer por que ele agiu. Porém, O’Connor acredita que razões podem participar da explicação de ações de outra forma, em que elas não sejam consideradas a causa da ação; isto é, de uma forma compatível com a causalidade do agente.

Em sua teoria, o autor considera desejos como sendo as razões do agente para agir. $\mathrm{O}$ agente agiria para satisfazer seu desejo que $\Theta$ (theta):

1. Anterior a essa ação, o agente teve um desejo que $\Theta$ e acreditava que agindo assim ele iria satisfazer (ou continuar satisfazendo) esse desejo;

\footnotetext{
${ }^{3}$ De acordo com essa concepção, propriedades são universais com tendências disposicionais essenciais.
} 
2. A ação do agente foi iniciada (em parte) pela sua própria atividade causal autodeterminada, o evento que compõe o vir-a-ser-de-uma-intenção-queaciona-o-assim-agir-para-agir-aqui-e-agora-para-satisfazer- $\Theta$;

3. Concomitantemente a essa ação, ele continuou a desejar que $\Theta$ e intencionava de sua ação que ela satisfizesse (ou contribuísse para satisfazer) esse desejo; e

4. A intenção concomitante era uma consequência causal direta (intuitivamente, uma continuação) da intenção acionadora-de-ação ocasionada pelo agente, e ela sustentou causalmente a conclusão da ação. (O'CONNOR, 2000, p. 86)

Contudo, explicações de ações que dão lugar para razões indeterminadas, como a apresentada por O'Connor, precisam responder à crítica de Donald Davidson (p. 18, 1980): o agente pode ter razões para fazer A e fazer A por outras razões, de modo que é difícil distinguir quais foram as verdadeiras razões que levaram o agente a agir nesse tipo de teoria. Todavia, O'Connor acredita que as condições citadas acima respondem à crítica de Davidson, em particular, a condição 3, que mostra que a intenção é produzida especificamente para satisfazer certo desejo do agente, além das outras condições, que ajudam a evitar casos inusitados e desvios.

Contudo, explicar como um agente poderia escolher qual de suas razões seguir não é uma tarefa simples. Suponhamos que um agente deseje tanto sair para passear, pois está cansado de ficar em casa, como deseje assistir televisão, já que seu programa favorito já vai começar. Ele deve escolher, mas não está claro como ele faz essa escolha, já que ele tem uma razão para agir de acordo com cada curso de ação diferente. O'Connor argumenta que razões teriam pesos diferentes, o que ajudaria a explicar as preferências do agente.

Segundo O'Connor, no entanto, razões não teriam uma relação causal com ações, pois as últimas seriam produzidas por uma intenção originada pelo poder causal do agente. Ainda assim, razões para agir, tais como desejos e crenças (O’CONNOR, 1995, p.86), figurariam na produção da ação, pois é no contexto de razões, e motivado por elas, que o agente exerce o seu poder causal para produzir a ação.

Igualmente, para explicar a preferência por algumas ações em detrimento de outras, O'Connor sugere que o agente teria uma propensão para gerar certo tipo de intenção e, considerando o agente como sendo uma causa, ele teria essa propensão graças a sua estrutura subjacente. Nesse sentido, razões aumentariam a propensão do agente para empreender certa ação A. Desse modo, a tendência está na causa e na sua estrutura; i.e., no agente, e não no efeito, e isso ajudaria a explicar a tendência do agente de empreender a ação A e não a ação B sem que seja necessário estabelecer que A é um curso de ação melhor do que B, pois a explicação estaria no agente e não na ação. 
O’Connor argumenta que a consciência é necessária para o exercício do poder causal do agente, pois ele não aceita que um agente possa estar completamente não consciente de sua intenção de agir (é possível que o agente nem sempre esteja completamente ciente de suas razões para agir, entretanto, não seria possível que um agente não tivesse consciência alguma de suas verdadeiras razões para agir). No caso em que se age sem consciência de agir, a ação não poderia ser considerada livre, pois sem estar ciente daquilo que o motiva, o agente não poderia controlar sua atividade.

E quanto ao caso limite - total ignorância consciente da própria intenção em agir? Aqui, eu acho, o teórico da agência deve dizer-o que é independentemente plausível—que não se age livremente. Eu, pelo menos, sou incapaz de conceber um agente que controle diretamente sua atividade sem qualquer consciência daquilo que o está motivando. $\mathrm{O}$ cenário mais próximo que posso imaginar é um em que eu esteja vagamente ciente de que eu tenho uma razão para executar a ação A e eu não consigo me lembrar qual é. Pressionado pelo tempo, eu procedo a fazer A. Eu estarei agindo por causa da minha razão não rememorada (supondo que ela causou a minha vaga sensação de que existe tal razão), mas não estarei agindo por [for] ela. $\mathrm{O}$ conteúdo da minha intenção não será que eu satisfaça o desejo $\Theta$; ao contrário, ele será que eu satisfaça o desejo ou intenção esquecidos relevantes para A. (O'CONNOR, 2000, p. 88).

Nesse contexto, o autor argumenta que razões não precisam diretamente produzir ações para que as expliquem, isto é, não é necessário conceber as razões como sendo causas da ação; pois quem inicia sua ação é o agente. E essa iniciação está conceitualmente ligada às razões que o agente tem para empreender a ação em questão. A ligação é clara, visto que agentes causam intenções por conta de motivações, ou seja, de suas razões para agir. Afinal, O'Connor defende que agentes não agem sem que tenham alguma motivação para tanto.

De acordo com essa compreensão, razões são o que influenciam e motivam o agente a produzir ações e, por isso, o agente não pode ser ignorante de suas razões para fazer A, se ele exerce seu poder causal para produzir uma intenção de fazer A. Caso contrário, se ele não estivesse pelo menos ciente delas, suas razões não poderiam influenciar o que ele escolhe fazer. Em caso de falta de consciência das suas razões para fazer A, se o agente faz A esta não seria uma ação livre. O’Connor argumenta que a ação não poderia ser explicada, uma vez que teria surgido sem que o agente tivesse ciência de qualquer razão para agir, consequentemente, sem que ele tivesse consciência de qualquer motivação para agir.

Para explicar como são possíveis ações que não são livres, são consideradas como não sendo livres as ações produzidas sem o envolvimento direto do poder ativo do agente, resultando apenas de estados mentais do agente. “[...] Dizemos o mesmo a respeito de ações 
não livres que são um resultado inevitável de fatores prévios" (O’CONNOR, 2000, p. 99). Para que uma ação seja considerada livre, nesse contexto, o poder do agente deve ser relevante para a produção da ação, não podendo estar apenas latente.

Segundo a teoria de O’Connor, razões são condições estruturantes para ações intencionais. Em alguns casos, as razões não estão conectadas ao processo de pensamento do agente no momento, a exemplo das ações automáticas que, apesar de espontâneas, são ativadas por instinto ou disposições enraizadas no agente. Nesses casos, creio que O'Connor não consideraria essas ações livres, já que o agente não as teria ativamente escolhido nem executado.

O'Connor defende que causas indeterminadas oferecem apenas uma probabilidade que se produza o efeito esperado. Portanto, não mostrar porque o agente fez A ao invés de fazer B não torna a CA menos explicativa, já que o agente deve ser visto como uma causa indeterminada. Ao satisfazer um desejo seu de uma maneira e não de outra, o agente estaria manifestando sua preferência, que poderia ter sido diferente. Até mesmo o fato de ele ter agido para satisfazer seu desejo no momento em que o fez poderia ter sido diferente, pois muitas vezes o agente pode simplesmente continuar deliberando sobre o melhor curso de ação a empreender.

\subsection{O problema do DA}

Uma crítica comum à CA é justamente que o tipo de causa que ela propõe na produção da ação seja uma causa sui generis, visto que é comum se aceitar uma visão naturalista do mundo, em que o mundo é causalmente fechado e, portanto, só haveria causalidade entre eventos (KIM, 1993). Suponho, no entanto, que O’Connor não consideraria essa crítica tão grave, já que ele está justamente propondo que há outro tipo de causalidade envolvida na produção de ações e que essa causa é distinta do tipo de causalidade que opera entre eventos.

Por sua vez, esse tipo de concepção da produção de ações vê um problema no tipo de explicação que não postula a causalidade do agente para explicar a produção de ações. Do ponto de vista do teórico da agência, um problema considerado bastante grave é gerado pela falta desse tipo de causalidade numa teoria que pretenda explicar ações, e pela tentativa de dar 
uma explicação que coloque as ações na ordem natural; i.e., uma teoria que proponha que ações são eventos que fazem parte da ordem causal do mundo e que são produzidas por causas antecedentes. Assim, o agente não teria um papel relevante na produção de suas ações, esse é o chamado problema do DA.

A capacidade de explicar ações da TCA foi desafiada por vários problemas apontados por seus críticos, como o problema do desvio na cadeia causal ${ }^{4}$ e o problema de explicar ações acráticas $^{5}$ por meio dessa teoria. Enquanto muitas das questões levantadas a seu respeito foram respondidas, uma das críticas preocupante que persiste é o problema do DA.

Os críticos da TCA, e mesmo alguns adeptos da teoria (VELLEMAN, 1992), consideram que esse tipo de explicação tem um problema grave: ela faz o agente desaparecer da produção da ação, pois em nenhum momento da explicação ele aparece exercendo um papel ativo nessa produção. Sem agente, as ações podem ser tratadas apenas como eventos na ordem causal natural do mundo, e muitos críticos dessa teoria se preocupam que isso faça parecer impossível que seres humanos ajam. Afinal, nós não teríamos, segundo essa concepção, participação ativa ${ }^{6}$ nas nossas ações, e as ações humanas seriam determinadas por fatores externos ao agente e fariam parte de uma cadeia causal que não estaria realmente relacionada àquele que age (NAGEL, 1986).

As acusações de que a TCA faz desaparecer o agente da ação são antigas, suas bases já apareciam na preocupação de A. I. Melden (bem descrita no seu artigo de 1991) a respeito das explicações causais para as ações e sua semelhança com as explicações causais para eventos naturais, que não são ações. Por isso, Melden preferiu uma explicação com base nas razões do agente para agir, na qual razões não são consideradas causas. A questão que se revelava era a de saber como, então, seria possível distinguir aquilo que alguém faz daquilo que acontece no mundo natural.

\footnotetext{
${ }^{4}$ Refere-se ao problema que surge para explicar ações por meio da explicação causal quando há um desvio na cadeia causal normal, que os defensores da TCA acreditam existir. Um exemplo de uma cadeia causal normal seria: o desejo de comer algo doce e a crença de que há uma torta de chocolate na geladeira participam causalmente na produção da ação de Marco de abrir a porta da geladeira para investigar suas possibilidades. Já um exemplo de desvio é o caso de Paulo, que deseja pedir sua namorada em casamento e acredita que ajoelharse ao fazer o pedido é a melhor forma de fazê-lo. Porém, Paulo fica tão nervoso no momento de fazer o pedido que suas pernas ficam bambas e cedem, de modo que ele cai de joelhos diante da moça. Nesse caso, Paulo fica ajoelhado, como pretendia, mas não por causa de suas razões para agir, bem como o agente não o fez da forma que pretendia, pois houve um desvio na cadeia causal que produziria a ação.

${ }^{5}$ Akrasia, do grego, se manifesta, de modo geral, quando o agente julga melhor fazer A no tempo $t$, porém, faz B intencionalmente em $t$.

${ }^{6}$ Eu considero essa expressão pouco clara quanto ao que significaria para um agente participar na produção de sua ação, afinal, é difícil imaginar uma ação da qual o próprio agente não participe. Mas deixarei a discussão sobre essa expressão para o capítulo 4.
} 
Esse tipo de exclusão que, segundo críticos, o agente sofre na TCA geraria dúvidas quanto à responsabilidade moral dos agentes sobre suas ações e a possibilidade de imputá-las legalmente aos mesmos, bem como estremeceria a noção de autoria dos agentes e a própria concepção de que fazemos coisas acontecerem. Tudo isso poderia abalar até mesmo a noção de identidade ${ }^{7}$ e responsabilidade de cada um.

Quando o poder ativo do agente é retirado da explicação das ações, elas não seriam ações do agente. Esse é um dos requisitos para que a ação seja considerada uma produção do agente; por isso, faz sentido que na teoria de O'Connor as razões devem motivar o agente a agir de certa forma, portanto, ele deve estar consciente de suas motivações para agir e deve diretamente exercer o seu poder ativo para produzir a intenção de agir. Portanto, uma teoria que postule que razões causam ações, como a TCA, deve explicar como essa poderia ser uma ação do agente, já que ele não participaria da sua produção, i.e., ele está desparecido da ação. Por isso o problema tem sido chamado de desaparecimento, falta ou alienação do agente.

Lowe aponta que falta à TCA o elemento executivo das ações intencionais, tratando-as meramente como acontecimentos (2008, p. 173). Ao explicar ações intencionais a partir de eventos mentais que as causariam, segundo Lowe, a TCA deixaria de fora justamente o que há de distintamente ativo sobre a ação, o que contradiria a própria experiência fenomênica de agir intencionalmente. ${ }^{8}$ Ou como coloca Chisholm (1978), a preocupação estria em saber se a causalidade do agente poderia ser reduzida à causalidade de eventos sem que a ação perdesse o seu significado em afirmações a respeitos de eventos como sendo causas e em que o agente não seria a origem de nenhuma atividade.

O problema do DA também pode ser visto como sendo uma objeção à concepção naturalista das ações. Segundo Thomas Nagel (1986, p. 110-114), o agente empreender sua ação não faz parte do mundo quando o mundo é pensado objetivamente, pois a ligação que cada agente sabe que tem com sua ação não tem lugar numa descrição objetiva do mundo.

Nagel (1986) argumenta que num mundo descrito pela física, química e biologia, mesmo que a última explique sensações, não há nada que distinga ações daquilo que acontece. Sua característica distintiva não pode ser tratada por nenhuma dessas ciências. ${ }^{9}$ Ações não são

\footnotetext{
${ }^{7}$ Paul Ricoeur (1990) defende a teoria de que a identidade é narrativa e, portanto, uma construção narrativa de uma trama com base nas ações do agente.

${ }^{8}$ Apesar de Lowe colocar esse problema, tradicionalmente conhecido como o problema do DA, ele reserva o termo DA para um problema semelhante ao apontado por Pereboom (2014), a respeito das ações livres.

${ }^{9}$ Por um lado, teorias que defendem que razões para agir fazem parte da produção das ações, porém, não como causas das mesmas, mostram uma clara diferença entre ações e eventos, ressaltando a peculiaridade das ações. As razões do agente explicariam suas ações mostrando o propósito com o qual ele agiu e o que ele visava atingir com sua ação, ressaltando o aspecto teleológico das razões. Porém, nesse caso é difícil explicar como as razões
} 
sensações nem sentimentos, nem são estados mentais como crenças e intenções; portanto, uma concepção que levasse em consideração apenas esses estados e eventos físicos não poderia incluir ações.

Ademais, o problema da ação não é o mesmo que o problema da liberdade, para Nagel, concedendo que ações tenham um aspecto irredutível, assim como o agente, mesmo num caso em que um agente não age livremente, ele ainda age. Assim, ações são distintas de ações livres, sendo as últimas apenas um tipo da primeira, e o problema geral da agência é mais amplo do que o da liberdade. Para explicar ações e agência seria preciso levar em consideração seu caráter distintivo, sem pretender reduzi-las a uma descrição objetiva de ações como sendo eventos, determinados ou indeterminados.

\begin{abstract}
Algo peculiar acontece quando vemos ações de um ponto de vista objetivo externo. Alguns de seus aspectos mais importantes parecem desaparecer sob o olhar objetivo. Ações não parecem mais atribuíveis a agentes individuais como origens, mas ao invés disso se tornam componentes do fluxo de eventos no mundo do qual o agente é uma parte. (NAGEL, 1976, p. 110)
\end{abstract}

Nesse sentido, o agente e a produção da ação passariam a fazer parte das circunstâncias e de um curso maior de eventos do qual ninguém é o agente. Todas as ações se encaixariam nesse fluxo e o agente passaria a ser visto apenas como uma parte do mundo e não como uma perspectiva do mundo, i.e., alguém que observa e tem sua própria perspectiva individual sobre o mundo.

Outro problema com a concepção objetiva das ações é que ela não deixaria espaço também para a autonomia do agente. Anscombe (1957) teria trilhado o caminho da explicação de ações por meio de razões, o qual Nagel considera mais apropriado para conceder o devido lugar ao agente. Efetivamente, no entanto, o autor acredita que nenhuma dessas teorias fornece uma explicação satisfatória para a questão.

Até mesmo o controle que normalmente supomos que o agente teria sobre sua ação é colocado em questão por essas mesmas dúvidas. Ora, se o agente é parte da ordem natural e suas ações são produzidas por causas precedentes, determinadas ou não, elas fazem parte dos acontecimentos do mundo, sobre os quais ele não tem efetivamente controle algum, também não tendo controle sobre suas ações. Afinal, ele não seria capaz de interferir na ordem natural.

Ainda de acordo com essa ideia, O’Connor considera que, para que uma ação seja uma ação que dependa [is up to] do agente-i.e., que esteja sob seu controle-a mesma não 
poderia ser causalmente determinada (2013, p. 230-231) se não, não dependeria do agente, nem poderia ser causada (de maneira indeterminada) por fatores externos. Nesse sentido, o agente não teria o papel necessário na ação, O’Connor sugere que ações sejam livres de acordo com a sua CA (vide seção anterior). ${ }^{10}$

Assim, o problema da ação e sua produção surgem dentro dessa oposição entre a concepção naturalista de ação, que a vê como um evento no mundo, e as concepções defendidas tanto por Nagel (1986) quanto pela CA, que concedem um caráter especial às ações, dado o aspecto fenomenológico e da perspectiva sobre o mundo característico à sua produção.

Jennifer Hornsby (2004) argumenta que nós sabemos que fazemos acontecer nossas ações (2004, p. 176) e que negar essa relação é propor que o agente esteja alienado de sua ação de uma forma impensável. Assim, de modo geral, as teorias preocupadas em explicar as ações humanas levam o agente em consideração como sendo uma parte importante daquilo que elas visam explicar. Por essas razões, alguns autores que aderem à TCA propõem melhorias para a teoria (VELLEMAN, 1992), para que ela possa responder a essa dificuldade; enquanto que outros, que não aceitam a teoria, propõem a sua eliminação por completo, por ser ela considerada inapropriada para explicar ações e por ela fazer desaparecer aquilo que caracterizaria ações.

Para David Velleman (1992), a explicação da TCA seria eficiente na sua maior parte, porém, ele argumenta que a teoria deixa o agente fora dos componentes da ação, ou ao menos não haveria espaço para reduzir o seu papel a um dos componentes da explicação causal da ação. Esse tipo de explicação leva em consideração apenas eventos e estados internos do agente como sendo causas da ação, sem considerar aquele que age como parte da mesma, como se ele não tivesse participação em sua produção. "Eventos psicológicos e físicos acontecem dentro da pessoa, mas a pessoa serve apenas como arena para estes eventos: ela não tem uma participação ativa" (VELLEMAN, 1992, p. 461).

Velleman afirma que não encontramos nenhum elemento na explicação causal que corresponda ao agente, ou à sua participação na ação (1992, p. 462). A TCA, segundo o autor, explicaria apenas ações das quais o agente não participa ativamente; todavia, há ações

\footnotetext{
${ }^{10}$ Essa objeção se assemelha à nova objeção da DA lançada por Derk Pereboom (2014), que é a objeção de que o agente não teria na TCA um papel causal suficiente para que pudéssemos atribuir-lhe controle suficiente sobre a ação e garantir sua responsabilidade moral sobre a mesma. Pereboom parece conceder que essa seria uma ação do agente, apesar de ele não ter controle suficiente para ser considerado responsável por sua ação. Eu considero que essa é uma nova versão do problema da DA, devido ao surgimento de uma nova geração da CA (JUDISCH, 2010) que requer que apenas ações livres teriam que ser produzidas pela causalidade do agente, o que se opõe às teorias mais antigas da CA, como a de Chisholm (1964).
} 
em que o agente tem participação ativa (o que não seria o caso dos reflexos nem das ações acráticas). A participação ativa, para Velleman, seria a característica distintiva das ações humanas. $\mathrm{O}$ autor propõe essa distinção também para destacar a noção intuitiva de que participamos ativamente (nota 11, 1994, p. 464) quando agimos; nesse sentido, ele se preocupa com a capacidade da explicação causal de capturar esse tipo de participação do agente em sua explicação para ações.

Paul Ricoeur (1990) também se depara com esse problema quando discute a diferença entre ações e eventos. Para saber o que é uma ação, é necessário mais do que identificar um padrão de movimentos que poderiam ser confundidos com qualquer outro evento que ocorre no mundo, como uma folha que cai da árvore. Para distinguir ações de eventos, Ricoeur (1990) defende que a distinção estaria na relação entre a ação e seu agente, e na compreensão do agente como sendo o princípio da ação. O agente iniciaria sua ação e, portanto, ele a faria acontecer; diferente dos eventos, que simplesmente acontecem. Nesse sentido, o poder de iniciar a ação garantiria que o agente tivesse estados de consciência que antecipariam a ação. Assim, o autor defende que tratar ações como eventos anônimos (sem referência ao agente), como o faz a TCA, colocaria um obstáculo para a identificação do papel do agente nas ações intencionais.

Mas não se trata apenas de fazer essa distinção, Ricoeur também faz referência ao aspecto fenomênico que existe no fato do agente se crer capaz de empreender uma ação (1992, p. 111) por conta de seu poder de agir (1992, p. 107), ${ }^{11}$ de modo que aceitar uma teoria da ação que não envolvesse agentes seria o mesmo que dizer que esse aspecto não teria lugar na explicação das ações humanas.

Essa seção visou apresentar o problema do desaparecimento do agente, tema central deste estudo, e seu contexto. Ficou claro que algumas suposições a respeito de como concebemos ações fazem parte da construção do problema; por exemplo, a noção de que o agente deve participar direta e ativamente na produção de sua ação, e até mesmo a noção do agente como um tipo de entidade com poderes característicos. Além disso, há outro contexto, identificado por Nagel (1986), no qual surge um problema quando se tenta encaixar o agente no fluxo causal natural. A grande questão, nesse caso, é que se o agente fizer parte desse fluxo, como a TCA concebe, ele será esvaziado daquilo que o caracteriza como agente.

Assim, essa forma de conceber a agência (principalmente a agência humana) como sendo um poder próprio do agente e que se distingue da causalidade entre eventos, de modo

\footnotetext{
${ }^{11}$ Schroeter (2004, p. 645) também propõe um poder do self consciente que iniciaria a execução de ações.
} 
que esse poder o distinguiria das outras coisas do mundo, é fundamental para compreender o problema do DA. É dentro desse contexto, em que a perspectiva daquele que age e sua experiência de ter agido ativamente são considerado relevantes para a produção da ação, que o problema do DA surge.

\section{Teoria Causal da Ação}

Nesta seção será apresentada a Teoria Causal da Ação (TCA). Serão abordados alguns pontos relevantes para as TCA como: o que seriam ações, e o porquê de convir uma explicação causal da mesma. Por fim, serão apresentados brevemente o papel de alguns estados mentais (intenção e motivação) na TCA. Diferentes autores propõem diferentes versões dessa teoria; porém, aqui será necessário restringir a presente discussão a um exemplo proeminente desse tipo de teoria, desenvolvido por Alfred Mele (1987, 1992, 2003).

A TCA vem sendo a ortodoxia da explicação de ações intencionais desde que Donald Davidson (1963) reintroduziu a explicação causal de ações na discussão contemporânea sobre ações humanas, ao lançar seu famoso desafio aos anti-causalistas: apresentar uma explicação para ações intencionais na qual as razões para agir do agente (ou seus realizadores físicos), ${ }^{12}$ em alguma das suas acepções, não desempenhem um papel causal na explicação da ação em questão (DAVIDSON, 1980, p. 09). Apesar de essa explicação ser bem sucedida em alguns aspectos, isso não quer dizer que esse modelo de explicação não tenha problemas, como o mencionado problema do Desaparecimento do Agente (DA). Todavia, antes de tratar de seus problemas é preciso conhecer a teoria causal, que não é única nem consensual, dado que diferentes autores apresentam variadas formulações da TCA.

Uma de suas versões mais atuais e completas é aquela desenvolvida por Alfred Mele, prolífico teórico da ação, que desenvolveu uma extensa teoria visando explicar causalmente ações intencionais humanas e discutir os diversos problemas que surgem para esse modelo explicativo, como o autocontrole, a autonomia e o livre arbítrio. Dada a sua abrangência e

\footnotetext{
${ }^{12}$ Usarei a expressão realizadores físicos para deixar claro que eu não pretendo resolver o problema de qual seria a relação entre estados mentais e atividade cerebral; porém, deve ficar claro também que a minha interpretação da TCA e a minha proposta de solução para o DA é compatível com a ideia de que os o papel causal desempenhado pelos estados mentais do agente são os mesmos de seus realizadores físicos. Nesse sentido eu concordo com Mele (2003, p. 6).
} 
influência, a teoria desenvolvida por Alfred Mele $(1987,1992,2003)$ será a base da presente discussão sobre a TCA.

Assim, nas próximas subseções será desenvolvida uma elucidação da TCA, especialmente como ela é defendida por Alfred Mele: na sessão 3.1. será discutido o que são ações intencionais; na sessão 3.2. será desenvolvida uma defesa do porquê Teorias Causais são relevantes para explicar ações; na sessão 3.3. será esclarecida a relevância da razões para agir, sempre tomando a teoria de Mele como base; na sessão 3.4., intenções serão discutidas; e, finalmente, motivações e sua importância serão o foco da sessão 3.5.

\subsection{Ações intencionais}

Se for aceito que toda ação é intencional sob alguma descrição da ação, como afirma Donald Davidson, então, o que caracteriza as ações é a sua intencionalidade; "um homem é o agente de um ato se o que ele faz puder ser descrito sob um aspecto que o faça intencional" (DAVIDSON, 1980, p. 46). Para Davidson, uma ação ter sido empreendida intencionalmente significa que uma combinação de um desejo mais uma crença causou essa ação, i.e., que a ação tenha sido causada por razões para agir do agente, pois o autor considera que intenções são redutíveis a esse par de estados mentais. "P1. Se um agente quer fazer x mais do que ele quer fazer y e ele se acredita livre para fazer x ou y, então ele vai intencionalmente fazer x se ele fizer qualquer uma, x ou y, intencionalmente" (1980, p. 27). Assim, fazer A é uma ação, se puder ser descrita sob um aspecto que a torna intencional e isso requer que, sob alguma descrição, o agente saiba o que está fazendo.

A intencionalidade distingue aquilo que simplesmente acontece daquilo que um agente faz, apesar de também serem possíveis ações não-intencionais, de acordo com a teoria de Davidson. Quando um agente deseja sentar-se à mesa e anda em sua direção, mas tropeça no tapete e cai, Davidson aceita que, nesse caso, o agente faz algo, pois ele tropeça durante um movimento intencional seu. Porém, sua ação de tropeçar não foi intencional. Já no caso de alguém esbarrar em $\mathrm{S}$ e ele derramar seu copo de suco, não se pode dizer que essa foi uma ação de $S$.

Calcular algo errado é uma ação de calcular para a qual o agente tinha uma intenção, a de calcular corretamente. $O$ agente não conseguiu fazer aquilo que ele tinha a intenção de 
fazer e não se pode dizer que sua ação de calcular errado foi intencional; porém, ele agiu não menos. ${ }^{13}$

Alfred Mele sugere que as TCA estariam de acordo com a tese C: "C. Para todas as ações A, A é uma ação intencional somente se o agente de A teve uma razão para fazer A e (ele ter) essa razão foi uma causa de ele fazer A" (MELE, 1987, p. 32). A proposta de explicar uma ação A citando as razões pelas quais A foi empreendida é a proposta de dar uma explicação causal para A. Assim, uma ação ter sido empreendida por uma razão é, segundo o autor, condição necessária para que uma ação seja considerada intencional pelas TCA.

Assim, o agente, $S$, ter uma razão para fazer A é condição necessária para que $S$ faça A intencionalmente, contudo, não é condição suficiente para tanto. Por isso, o princípio $C$. afirma que A é uma ação intencional somente se o agente teve uma razão para fazer A. Mele tem o cuidado de não afirmar que uma razão para agir é condição suficiente para um agente empreender uma ação intencional, pois é possível que, mesmo tendo uma razão para fazer A e mesmo fazendo A, o agente não aja intencionalmente. Por exemplo, eu tenho sede no momento, eu desejo beber, mas não o faço. Eu opto por continuar escrevendo mais alguns parágrafos.

Casos de desvio na cadeia causal também exemplificam essa possibilidade. Gina é bastante distraída. Seu dermatologista lhe receitou recentemente um creme noturno, para manter a jovialidade de sua pele, e um protetor solar, para usar durante o dia. Como ela sabe que é distraída e sabe que se confunde, principalmente quando se sente pressionada, Gina presta muita atenção aos horários e cremes que ela deve aplicar no rosto e posiciona os cremes estrategicamente de uma forma que evite confusão, o creme à direita e o protetor à esquerda da pia.

Hoje Gina perdeu a hora e, pretendendo obedecer aos seus horários, se apressou para aplicar o protetor solar. Ela tinha razões para fazê-lo que a levaram a agir (desejava cuidar bem de sua pele e manter sua aparência jovial, mesmo o horário de aplicação já tendo passado). Mas Gina se sente tão pressionada pela pressa que se confunde a respeito dos

\footnotetext{
${ }^{13}$ Por sua vez, para Davidson, ser o agente de uma ação é fazer algo intencional em pelo menos uma de suas descrições (1980, p. 46). Davidson, no entanto, visa desenvolver uma caracterização de ações que não dependa de intenções (1980, p. 47), pois um agente poderia ser o agente de uma ação a qual o mesmo não teve a intenção de empreender; por exemplo, um agente pode acender a luz e alertar um ladrão de que há gente em casa, assim, ao fazer a primeira coisa intencionalmente, o agente não tinha a intenção de fazer a última, mas o fez (1980, p. 53). Outras consequências que o agente não teve a intenção de fazer podem se seguir de sua ação intencional (e esse é o caso apenas quando há uma ação intencional). Davidson conclui que uma ação ser intencional é intensional (usado aqui no sentido de que o conceito de intencionalidade não necessariamente se aplica a todas as descrições da ação, i.e., oposto de extensional) e, portanto, não caracteriza todas as ações; afinal, alertar o ladrão também é uma ação do agente. Contudo, a investigação não resultou numa analise da relação entre o agente e sua ação em que essa relação seja independente de intenções (1980, p. 61)
} 
cremes e acredita que deve aplicar o conteúdo do tubo à direita da pia. Por sorte ela está tão atordoada por ter acabado de acordar e precisar correr para o trabalho que, ao mesmo tempo em que apressa sua filha para se aprontar para ir à escola, ela distraidamente apanha o tubo à esquerda da pia e aplica o protetor solar no rosto.

No caso de Gina poucas pessoas aceitarão que ela intencionalmente aplicou protetor solar no rosto. Ela teria aplicado o creme à direita da pia, se não tivesse se atrapalhado com a pressa. Assim, não basta ter uma razão para fazer A e esta participar causalmente na produção da ação A para que a agente aja intencionalmente. Para que a participação de uma razão para agir na produção causal de uma ação seja condição necessária $e$ suficiente da ação, ela deve causar a ação da forma apropriada, ou seja, sem desvio.

Igualmente, Mele (1992) considera controverso afirmar que uma ação intencional A seria uma ação empreendida com a intenção de fazer A, pois um agente pode ter a intenção de matar uma pessoa atirando no seu coração, mas ele pode errar e atirar no seu pé, matado a vítima mesmo assim, porque ela era hemofílica, detalhe desconhecido pelo assassino. Sem dúvida o agente atirou contra sua vítima intencionalmente. Também é possível afirmar que ele deve ter tido uma razão para matá-la; porém, como o assassino mata sua vítima com um tiro no pé—o que ele não tinha a intenção de fazer, pelo menos não desse modo—fica a dúvida se ele a matou por uma razão. Seria a ação intencional, mesmo tendo saído tão diferente do pretendido? Assim, parece que uma ação pode ser intencional mesmo que o agente tenha agido sem uma intenção específica.

Igualmente, é possível que um agente tenha uma intenção que contribui causalmente para a produção da ação que poderia mesmo assim não ser considerada uma ação intencional. Por exemplo, Jorge, um jogador iniciante, pode ter a intenção de tentar acertar um dardo no alvo, pois ele está distante e considera jogar dardo bastante difícil. Se ele acerta o centro do alvo, seu acerto pode ser atribuído demasiadamente à sorte para ser considerado uma ação intencional. Assim, Mele tenta transpor esses obstáculos propondo que "um agente intencionalmente fazer $\mathrm{A}$ depende de ele ter alguma intenção pertinente, mas não necessariamente uma intenção de fazer A” (1992, p. 132). Desse modo, fazer A seria alcançado pelo agente ao fazer B, com a intenção de fazer B (1992, p. 134). No caso de Jorge, sua intenção de tentar acertar o alvo o levaria a acertar o alvo ao tentar acertar o alvo; assim, ele teria agido intencionalmente.

Nesse sentido, a distinção entre ações intencionais e não intencionais não estaria em terem elas uma intenção específica para fazer a ação em questão, o componente de plano da intenção pode ser outra ação que o agente visa empreender e que envolve empreender a 
primeira. ${ }^{14}$ Segundo as TCAs desenvolvidas por Alfred Mele (1992, 2003) e Michael Bratman (1984), intenções fazem parte da produção causal de ações; uma intenção para agir (mas não necessariamente para fazer A especificamente) ${ }^{15}$ participa da produção causal da ação A. De modo que, expor a intenção em vista da qual uma ação é empreendida é tornar saliente que se trata de uma ação empreendida por um agente por causa de uma intenção pertinente. ${ }^{16}$

Assim, daqui por diante, quando o termo ação for utilizado, esse estará sendo tratado de acordo com a acepção de ação intencional de Mele, descrita acima (a não ser que seja explicitamente indicado que se está tratando de outra concepção de ação). A TCA desenvolvida por Alfred Mele (2003) visa explicar as ações intencionais humanas, podendo ser elas de vários tipos: racionais e irracionais, moralmente louváveis e reprováveis, ações mentais e manifestas, ${ }^{17}$ e ações que envolvam bastante o agente e outras menos. No contexto de todas elas o agente é caracterizado por ser um ser humano que age.

Mesmo as TCA variando em diferentes aspectos em suas explicações de ações e nas soluções apresentadas para os problemas encontrados nas teorias, Mele acredita que toda teoria causal é desenvolvida a partir de uma perspectiva comum, a Perspectiva P:

No coração dessa perspectiva — eu a chamo "perspectiva $P$ " - estão um par de teses: (1) toda ação intencional é causada (mas não necessariamente de forma determinista); (2) no caso de qualquer ação intencional, uma explicação causal moldada parcialmente em termos de itens mentais (eventos ou estados), incluindo atitudes que englobam motivação, está disponível a princípio. (MELE, 2003, p. 05)

Esse tipo de perspectiva concebe a explicação das ações tomando como base os eventos mentais que a causam. ${ }^{18}$ A perspectiva $P$ parte de uma concepção naturalista da agência humana, defendendo que eventos mentais têm uma relação causal com ações, que são também eventos. Porém, as teorias que compartilham dessa perspectiva enfrentam a dificuldade de explicar, por exemplo, a relação entre o que nela é chamado de estados mentais e os estados físicos, e como é possível que os primeiros desempenhem um papel causal nessa

\footnotetext{
${ }^{14}$ Varia de acordo com teoria, e, possivelmente, de acordo com as intuições de cada leitor, quais ações seriam consideradas não-intencionais. Algumas possibilidades seriam ações causadas por um desvio na cadeia causal de sua produção, ações que dependem demasiadamente da sorte, reflexos, erros, ações de certos animais.

${ }^{15}$ É possível, segundo Alfred Mele (2003), que um agente tenha uma intenção de fazer A que participa na produção da ação B; por exemplo, um agente pode ter a intenção de ir ao trabalho, o que participa na produção causal da sua ação de entrar em seu carro e dirigir até o seu trabalho.

${ }^{16}$ Que tem uma relação causal com a ação.

${ }^{17}$ Ações que envolvem movimento corporal periférico.

${ }^{18}$ Diferente de outro tipo de explicação que sugere que ações seriam explicadas pelas razões do agente (MELDEN, 1991; HONSBY, 2004) para agir, porém, sem que essas razões fossem causas da ação. Essa teoria então se distingue da TCA e da CA.
} 
explicação, i.e., o problema da causalidade do mental. O que abre espaço para ampla discussão e diferentes soluções, além do problema do DA.

Segundo Mele, a abordagem causal das ações caracteriza ações com base na sua produção causal (história causal); i.e., para que um evento seja uma ação ele deve ser causalmente produzido da forma apropriada (por eventos mentais, como intenções), do mesmo modo que a moeda de uma nação e que as queimaduras de sol. O mesmo é o caso da concepção davidsoniana, em que toda ação é causalmente produzida por desejos e crenças do agente.

Assim, Mele explica que ser uma nota de um dólar americano se deve, parcialmente, a ter sido produzida da forma apropriada pelo Departamento do Tesouro dos EUA, da mesma forma como uma queimadura de sol é uma queimadura de sol devido, parcialmente, a ter sido causada pela exposição excessiva ao sol. Se um criminoso produz notas muito parecidas com as genuínas, mesmo usando as placas e papel do Tesouro, elas não serão notas de dólar genuínas; serão falsas. Do mesmo modo, se uma queimadura se assemelha muito a uma queimadura de sol, mas não foi causada pela exposição ao sol, ela não é uma queimadura de sol.

Assim, nas teorias que favorecem uma abordagem causal, ações também são caracterizadas com base na sua produção causal:

De modo similar, de acordo com AC [Abordagem Causal], certo evento ocorrendo em $t$ é Norm levantando sua mão direita em $t$-uma açãoparcialmente em virtude de ter sido produzido "da forma correta" por certos itens mentais (ou seus realizadores neurais). Um evento que outra pessoa produz dissimuladamente por meio de um controle remoto-inclusive um visivelmente indistinguível levantar da mão direita de Norm não produzido por um desejo ou intenção de Norm nem por um evento mental associado (ou, novamente, realizadores pertinentes) — não é um levantar da mão direita de Norm, mesmo que Norm sinta como se ele estivesse levantando a mão. (MELE, 2003, p. 52)

Assim, a história causal da ação é essencial para a sua caracterização, de acordo com a concepção que Mele (2003) apresenta de ações, pois desejos e/ou intenções têm necessariamente um papel causal na produção de ações, segundo a sua teoria, e esses itens mentais não participam da produção causal de eventos que não sejam ações. Experimentos de neurociência parecem apresentar evidências para tanto, como no experimento de Desmurget et al. (2009) em que os pacientes apenas consideram ações suas aqueles movimentos produzidos a partir do estímulo de uma área específica do cérebro, que engendrava neles o que os experimentadores chamaram de uma intenção. 
Assim, Mele (2003) acredita estar implícito que a ação de levantar a mão até alcançar um objeto é explicada por uma série de eventos fisiológicos (sinais de comando e movimentos corporais) causalmente iniciados pela aquisição, ou formação, de uma intenção (ou seu realizador físico), e causalmente sustentados e guiados pela persistência dessa intenção. Nessa abordagem, a intenção inicia, guia e sustenta a ação, o que é suficiente para tornar verdadeiro que o agente ergueu a mão para alcançar o objeto, fornecendo assim uma explicação também teleológica para o evento.

\subsection{Por que uma teoria causal da ação?}

Mantendo em mente a concepção de ações intencionais apresentada acima, Mele propõe uma explicação para ações intencionais. Normalmente aceitamos que, se existem ações, seres humanos certamente agem; contudo, dependendo do quão abrangente for a concepção de ações aceita, é possível estender a agência a outros seres. O presente estudo, entretanto, se concentra nas ações humanas, sendo assim, é importante perguntar: o que pretende uma explicação causal das nossas ações?

A TCA oferece uma explicação a partir do papel causal desempenhado pelos itens mentais pertinentes para as ações, como desejos e outros estados que englobem motivação, crenças, decisões, e intenções. Esses itens participam causalmente da produção das ações intencionais, além de explicitar as razões pelas quais o agente faz A, e isso torna possível compreender porque ele fez A. Ademais, a TCA defende que sem apresentar a relação causal entre os itens mentais pertinentes e a ação não é possível mostrar que os primeiros contribuem para a produção da última, nem que haja alguma relação entre eles.

Assim como Davidson, Mele defende que aquilo que caracteriza ações intencionais como tal é a sua produção causal (MELE, 1987). Para o último, os itens mentais que participam nessa produção são as razões do agente para agir, o que não limita a caracterização das ações intencionais à intenção.

Davidson (1980) foi influente na defesa de que ações intencionais são explicadas pelas razões que o agente teve para agir. A racionalização é uma explicação causal que visa mostrar o objetivo do explanandum (aquilo que será explicado, isto é, a ação). Assim, tornar saliente o objetivo pelo qual se agiu tem um papel fundamental nesse tipo de explicação, pois a 
racionalização esclarece o objetivo que o agente desejava (tinha alguma motivação para) atingir ao empreender a ação. Nessa teoria, racionalizar a ação a explica ao tratar a razão como causa da ação, o que constitui uma explicação causal da ação. Assim, as razões do agente para agir causariam a ação.

Duas noções são essenciais para esse tipo de explicação: causalidade e racionalidade; visto que a razão primária pela qual o agente age — desejo A mais crença de que fazendo B obtém A-constitui a causa da ação, e conhecendo essa causa é possível racionalizar a ação; i.e., saber por qual razão o agente agiu. Nesse sentido, Mele argumenta que, se Davidson estava correto ao defender que toda ação intencional é empreendida por uma razão e algo só é uma razão para fazer A se causa A, e essa é uma relação causal, o autor sugere que deve haver uma teoria causal para explicar ações. O autor, portanto, defende que itens mentais fazem parte dessa teoria e que são causalmente relevantes para as ações humanas. ${ }^{19}$

Explicações causais desse tipo aceitam que ações sejam compreendidas também teleologicamente (isto é, que elas possam ser compreendidas com base na finalidade que visam alcançar), visto que ações são direcionadas a algum objetivo. Prova disso, para Mele, é que estados representando objetivos, como desejos e intenções, figuram nas explicações. Todavia, segundo essa compreensão teleológica de ações é interpretada como sendo causal; i.e., os eventos considerados ações são explicados por serem causados por estados mentais (ou seus realizadores físicos). Além disso, as ações são caracterizadas como tal, de acordo com as TCA, por conta da sua história causal.

\subsection{Razões para agir}

Mele (1992) afirma ser irrelevante se razões são consideradas simplesmente estados psicológicos ou se são consideradas estados psicológicos no qual o sujeito se encontra ao

\footnotetext{
${ }^{19}$ Mele (1992) defende, entretanto, que o papel das crenças nas ações não é produzir uma razão para agir em conjunção com um desejo, como sugere Donald Davidson (1980). O desejo de matar a sede combinado à crença de que bebendo água é possível matar a sede, de acordo com Davidson, são a razão do agente para beber água. Nisso é possível perceber uma distinção entre as teses de Davidson e de Mele. O último acredita que o papel da crença é, na verdade, o de fornecer o conteúdo de representação necessário para os desejos, que seria o conteúdo da crença. Pois desejos têm, segundo Mele, um aspecto conativo (que compele à ação), mas também têm conteúdo de representação; afinal, para que o agente deseje A é necessário que ele tenha alguma concepção de A, que é desejável para ele. Assim, as crenças que o agente tem a respeito de A são responsáveis por como o agente concebe aquilo que deseja.
} 
pensar nessas propriedades abstratas..$^{20} \mathrm{Em}$ ambos os casos, atribuir razões significa atribuir estados psicológicos. A teoria causal de Mele propõe que uma razão para agir é necessária para a explicação das ações, mas ter uma razão não é suficiente para que o agente aja; pois ele precisa também ter a habilidade de agir, não estar impedido de agir por forças exteriores, nem por desejos concorrentes que intervenham na produção causal da ação.

As TCAs aceitariam essas condições, segundo Mele (1987); portanto, admitir que é necessário mais do que razões para explicar ações não é uma ameaça para a teoria, mesmo que isso envolva os realizadores físicos dos estados psicológicos envolvidos. Outros aspectos a respeito do agente são também relevantes para explicar ações intencionais; por exemplo, o seu autocontrole ou porque do agente estava mais motivado a fazer A do que a fazer B (visto que isso não envolve razões).

Mele reconhece que quando possíveis cursos de ações competem, passa a ser mais difícil explicar porque o agente agiu de acordo com a razão para fazer A e não de acordo com a razão para fazer B; principalmente no caso das chamadas ações acráticas. ${ }^{21}$ Não é suficiente afirmar que o agente estava mais motivado a agir de acordo com uma ou outra razão; afinal, isso é óbvio. Para que seja possível fornecer uma explicação para ação acráticas, por exemplo, a questão passa a ser mostrar por que o agente estaria mais motivado a agir contra o seu julgamento.

Mele então argumenta que, se fundamentar a explicação das ações na motivação que o agente tem para empreender uma ação não é suficiente para explicar ações acráticas, então também não o é para explicar ações continentes. ${ }^{22}$ Afinal, não é garantido que o agente agirá de acordo com o seu julgamento sobre o que é melhor fazer, mesmo que ele tenha razões para agir de acordo com esse julgamento e mesmo que ele tenha motivação para tanto.

Assim, as ações acráticas provam a insuficiência das razões para agir nas explicações de ações. Mele (1987) chega a afirmar que a explicação de uma ação acrática não está na razão pela qual o agente a empreendeu, pois isso seria trivial. O que efetivamente a explica é o porquê do agente ter agido de acordo com sua razão acrática ao invés de ter agido de acordo com sua razão concorrente (continente). Não basta dizer que o agente estava mais motivado a

\footnotetext{
${ }^{20}$ Essa é uma resposta para o problema: se razões contribuem de forma significativa para causar ações, como propõe a TCA, então razões devem estar no agente. Porém, para aqueles que acreditam que razões são proposições, não faz sentido considerar que essas propriedades abstratas estejam localizadas no agente.

${ }^{21}$ Grosso modo, ações acráticas são ações em que a razão pela qual o agente age intencionalmente vai contra o seu julgamento prático sobre o que é melhor fazer; i.e., ações que vão contra o seu julgamento do que é melhor fazer.

${ }^{22}$ Ações continentes são ações que não são acráticas. Ações continentes são, segundo Mele, "ao menos aproximadamente, ações de acordo com o julgamento do agente do que é melhor" (MELE, 1987, p. 99) fazer.
} 
fazer A do que a fazer B, para Mele, explicar a ação nesses casos consiste em mostrar porque as motivações do agente estavam balanceadas de tal forma.

Contudo, essa não é uma proposta para rejeitar a explicação de desejos-crenças para ações, pois, o autor defende a adoção de uma versão mais fraca dessa explicação que leve em consideração a participação causal de razões para agir nas ações, mas que também permita que outros fatores figurem na produção da ação. Assim, Mele afirma "que ações intencionais são ações empreendidas por razões e que as razões pelas quais agimos aparecem significativamente na etiologia das nossas ações intencionais" (1987, p. 97-98). Essa versão da teoria incorporaria os seus elementos antigos; afinal, o autor concorda que, na ausência de motivações concorrentes, apenas citar a razão pela qual o agente fez A efetivamente explica a ação.

Para o autor, vários elementos psicológicos fazem parte das explicações de ações. Muitos tradicionalmente figuram nessas explicações, como desejos, crenças, intenções, raciocínio prático, habilidades, julgamentos práticos sobre do que é melhor fazer; já outros são elementos novos, como as bases motivacionais positiva, negativa ${ }^{23}$ e total, a condição de atenção do agente, a proximidade temporal de recompensas, o autocontrole, a motivação para empregar o autocontrole, etc.

A explicação de ações continentes pode envolver elementos psicológicos distintos; Mele exemplifica afirmando que uma ação pode ser explicada em vista da base motivacional dos desejos concorrentes do agente, bem como da sua condição de atenção. O raciocínio prático e a proximidade de recompensas pode influenciar o balanço das motivações do agente, podendo o primeiro influenciar a condição de atenção do agente e o segundo a base de alguma motivação, caso se perceba que outro objetivo do agente seria favorecido se ele agir de acordo com o desejo A. Igualmente, o julgamento do agente sobre o que é melhor fazer pode influenciar o balanço das suas motivações, incitando um exercício de autocontrole bem como influenciar a condição de atenção do agente, mudando o seu foco para a ação julgada melhor.

Mele especifica o que é ter uma razão para agir: "ter razões efetivas - isto é, ter estados de razão efetivos - possui um elemento conativo e um elemento representativo que liga a conação ao comportamento apropriado" (MELE, 1992, p. 115). Ambos os tipos de elementos levam à ação, pois contribuem para a formação, ou aquisição, de uma intenção pertinente.

\footnotetext{
${ }^{23}$ Tudo aquilo que oferece motivação para fazer A e para não fazer A, respectivamente.
} 
2**. Qualquer razão pela qual uma pessoa age tem um elemento conativo que motiva a busca de um objetivo ou um sub-objetivo e um elemento representativo que constitui um plano, ou um elemento de um plano, para alcançar o objetivo pertinente ou sub-objetivo. (MELE, 1992, p. 110).

Portanto, é importante investigar por que intenções são necessárias para explicar ações, se o balanço das motivações do agente já as explica—visto que não basta dizer que o agente fez A porque tinha a intenção de fazer A. Mele (1987) acredita que intenções têm um componente de representação que desempenha o papel cognitivo de iniciar e guiar ações, coisa que vai além do papel funcional de outras atitudes que englobam motivação.

\subsection{Intenções}

De acordo com a teoria de Mele (1992), intenções medeiam razões para agir e ações; portanto, a explicação sobre o que são intenções é necessária para mostrar como elas influenciam ações. Essas não necessariamente incorporariam a motivação mais forte do agente, o que leva à dúvida sobre como intenções gerariam ações intencionais.

Primeiramente, o autor se preocupa em distinguir intenções de desejos: “[...] intenções e simples vontades $[\text { want }]^{24}$ têm papeis funcionais diferentes na produção de ações intencionais" (MELE, 1992, p. 77). Em virtude disso é importante saber qual é o papel funcional da intenção. Mele sugere que essas têm maior capacidade de produzir ações do que vontades/desejos que não estejam incorporados em intenções.

“[...] A função acional específica de meras vontades [want] é induzir e sustentar intenções adequadas, enquanto que a das intenções é iniciar, sustentar e guiar ações intencionais. O elemento motivacional de cada estado poderia desempenhar um papel funcional diferente” (MELE, 1992, p. 77). Assim, não seria simplesmente a força de motivação (variável) desses estados mentais que causariam ações, outros aspectos funcionais também estariam envolvidos nisso. Isso explica como pode haver empate entre as forças de motivação de fazer A e de fazer B e, ainda assim, o agente intencionalmente fazer A, dado que a intenção poderia desempenhar um papel relevante nesse desempate devido ao seu papel funcional que lhe é característico.

\footnotetext{
${ }^{24}$ Nesse sentido de vontade—como tradução do termo want—a vontade é entendida de maneira intercambiável com desejo.
} 
Nesse sentido, intenções seriam fundamentais para a produção de ações, e saber como se constituem e como se distinguem de desejos de ação é relevante para explicar ações. Intenções, para Mele, são: “atitudes executivas direcionadas a planos” (MELE, 2003, p. 27). Seu conteúdo de representação é um plano de ação, que não engloba força de motivação, pois é possível ter um plano sem estar motivado a executá-lo.

$\mathrm{O}$ enredo do plano pode ir do mais simples, uma representação do fim visado ( $\mathrm{S}$ viajando para o Havaí), até a complexidade extrema de conter todos os passos dos meios para um fim. Apesar de Mele admitir que comumente expressamos intenções fazendo referência apenas a um ponto do plano, isso não significa que o plano inteiro se resuma àquele único ponto; por exemplo, a intenção de $\mathrm{S}$ de checar seus e-mails não envolve um plano que se resuma apenas a isso, o plano normalmente envolve ligar o computador, abrir o seu navegador padrão, ir para a página do e-mail, digitar o seu login e senha, etc. E a condição de satisfação de uma intenção seria que ela fosse guiada pelo plano que constitui seu conteúdo.

Mele (1992) acredita que diferentes atitudes psicológicas, como desejos, crenças e intenções, podem ser distinguidas pelos seus conteúdos e orientações. A orientação de uma atitude pode ser: crer, desejar e intencionar. Para o autor, o que caracteriza intenções e a diferencia de outras orientações é a dimensão executiva que lhe é intrínseca, pois quando um agente tem uma intenção direcionada ao plano A isso significa que ele está resolvido a executar A.

Apenas intenções (e decisões) implicam nessa resolução, o que as distingue de desejos segundo Mele. Quando um agente deseja fazer A, não importa a força da sua motivação nem a conjunção dessa com uma crença pertinente, ter o desejo pertinente não implica que ele esteja resolvido a fazer A. Assim, de acordo com essa concepção, intenções têm importância fundamental para as ações intencionais, pois apenas elas implicam na resolução de fazer A necessária para produzir a ação.

De acordo com essa compreensão, intenções não podem ser reduzidas a pares de desejos mais crenças, o que fica claro por conta da dimensão executiva que lhe é característica. Mele (2003) defende que sua dimensão executiva se deve ao fato de intenções englobarem motivação, ou seja, sem motivação intrínseca para agir não seria possível que essas atitudes tivessem a dimensão de resolução que têm, visto que lhes faltaria o elemento de comprometimento psicológico que leva à resolução.

Não fica claro como Mele acredita ser possível que o fato das intenções englobarem motivação, assim como desejos, possa distingui-las dos desejos, engendrando um aspecto que lhe é característico, isto é, sua dimensão executiva. O autor afirma que ambas as atitudes têm 
uma dimensão de representação e uma de motivação, mas que são funcionalmente diferentes, apesar dessas semelhanças. Ao que parece, Mele quer dizer que a distinção funcional entre as duas atitudes é responsável por como a dimensão de motivação de cada uma se manifesta na produção causal da ação, de modo que a intenção assume a função executiva. Assim, o papel funcional é o que caracterizaria cada atitude.

Mele (1992) limita sua investigação às intenções proximais, mas admite que intenções, de modo mais geral, podem ajudar a coordenar o raciocínio prático, como sugerido por Michael Bratman (1999). Essa investigação mistura duas abordagens, uma visando entender o papel das intenções nas ações intencionais, ou seja, um estudo da sua função, e outro estudo das intenções elas mesmas, independentemente do seu papel.

Para tanto, Mele primeiro enumera e discute as diferentes funções das intenções na produção das ações intencionais: essas muitas vezes têm o papel de (1) iniciar e sustentar motivadores de ações intencionais, visto que intenções são, geralmente, concebidas como tendo participação nas causas de ações intencionais. Entretanto, intenções não apenas iniciam ações bem como têm a função de sustentá-las. Essa função deve ser, pelo menos parcialmente, conativa ou motivacional; pois se um sujeito deixa de ter a intenção de fazer A enquanto faz A, ele provavelmente parará de fazer A e o agente perderá justamente a sua motivação para fazê-lo.

O que não significa que para que um agente faça $A$ intencionalmente ele tenha que ter especificamente a intenção de fazer A (como foi visto na seção 3.1.), pois ele pode ter a intenção de tentar fazer A ou a intenção de fazer B. Por exemplo, Grace, uma exímia jogadora de sinuca está prestes a ganhar o jogo; para tanto, ela precisa apenas acertar a última bola na caçapa. É sua vez de jogar. A jogada é difícil, dada a sua experiência e habilidade, Grace acredita que tem $32 \%$ de chance de conseguir completar a jogada com sucesso. Ela precisa se concentrar bem. Grace tem, então, a intenção de tentar colocar a última bola na caçapa.

Nesse sentido, Mele acredita não ser necessário ter a intenção específica de fazer A para que o agente faça $A$. A agente pode ter a intenção de fazer $B$, ou, se a agente não acredita que vá conseguir fazer A, ela pode ter a intenção de apenas tentar fazer A e, ainda assim, fazer A intencionalmente.

(2) Intenções têm também a função de guiar a execução da ação e, possivelmente, de monitorá-la, segundo Mele. Um agente segue um plano quando o último aparece apropriadamente na etiologia da ação (MELE, 19992b). E, muitas vezes, o plano que compõe a intenção é fundamentado nas crenças do agente; isto é, se um agente tem a intenção de fazer 
A e acredita que fazer B levaria a fazer A, a intenção de fazer A incorpora o plano de fazer B como meio para fazer A.

Haveria dois tipos de intenções quando o tempo é levado em consideração: intenções próximas, para o presente; e intenções distantes, para o futuro não imediato. Isso está de acordo com a teoria de Michael Bratman (1984) segundo a qual (3) intenções distantes fazem parte de um plano maior que coordena as ações do agente ao longo do tempo, pois controlam o seu comportamento, resistem à revisão (até certo ponto), dispõem o agente a raciocinar em vista da satisfação de intenções e a ser consistente. ${ }^{25}$

Outra função desempenhada pela formação ou aquisição de uma intenção é, muitas vezes, (4) dar início ou finalizar um raciocínio prático (MELE, 1992). Porém, esse nem sempre é o caso: às vezes, uma intenção não inicia um raciocínio prático porque a situação não pede que algo seja resolvido por meio do raciocínio. Afinal, nem todas as ações necessitam de deliberação prévia; um exemplo seria quando o agente pega suas chaves para sair de casa. Ademais, nem sempre a aquisição ou formação de uma intenção finaliza um processo de raciocino prático, pois é possível não chegar ao fim da reflexão prática e continuar deliberando a respeito, sem resolver agir.

Vistas as funções das intenções, fica claro que essas são distintas de desejos e de outros estados motivacionais, pois ter a intenção de fazer A não é o mesmo que ter uma motivação mais forte para fazer A do que para fazer qualquer outra coisa. É possível ter uma motivação preponderante (a mais forte que o agente tem no momento) para fazer A e não estar resolvido a fazê-lo. Ter um desejo ou uma vontade [want] de fazer A não significa o mesmo que ter a intenção de fazê-lo e, portanto, estar resolvido a fazer A; por mais que desejos também tenham conteúdo de motivação, Mele defende que intenções estariam um passo além dos desejos no processo de causar ações.

Por conta do seu conteúdo de representação, intenções próximas são capazes de iniciar e manter ações: “qual ação(s) uma intenção gera é uma função parcial do componente de plano da intenção" (MELE, 1992, p. 144). Intenções incorporam planos para agir, de modo que, um agente é capaz de executar uma intenção se é guiado pelo plano representado nela. Assim, para Mele, ter uma intenção seria estar resolvido a executar um plano de ação, que seria próximo ou distante dependendo apenas do aspecto temporal da intenção (1992, p. 145).

\footnotetext{
${ }^{25}$ Assim, pareceria que acreditar que vai provavelmente agir de acordo com a sua intenção seria importante para a coordenação de planos que envolvem intenções próximas e distantes. Contudo, Mele acredita que intenções não são condicionadas por crenças, no máximo o agente precisaria crer ser capaz de agir de acordo com sua intenção, não mais do que isso. Assim, o agente não precisa acreditar que vai seguir seu plano de ação por inteiro, ele precisa apenas ser capaz de ir agindo de acordo com cada intenção envolvida no plano.
} 
A teoria de Mele (1992) visa capturar as funções da intenção numa hipótese de explicação para as ações segundo a qual adquirir uma intenção é começar a agir e ter a intenção de fazer A é estar resolvido a fazer A. O componente de plano da intenção é responsável pela sua capacidade de guiar a execução da ação, por isso a intenção sustenta a ação até o fim, não apenas a inicia.

Segundo a teoria de Mele (1992), a capacidade de coordenar nossas ações em relação umas às outras e em relação às ações das outras pessoas deriva da resolução incorporada nela e do plano de ação que ela contém; o que está de acordo com a teoria de Bratman (1999). Para tanto, basta que o agente tenha planos mais extensos que abranjam as ações menores e mais imediatas. Os planos são influenciados por aquilo que o agente já está resolvido a fazer, pois sua resolução motiva o começo do raciocínio prático, do qual depende a coordenação das ações. Contudo, o fato de o agente estar resolvido a agir quando ele tem a intenção de fazer A, não significa que sua intenção não possa ser revisada (Bratman, 1984, 1999, 2001).

O que caracterizaria intenções como tal, segundo Mele, é seu aspecto executivo desempenhado pela sua função de iniciar ações. Assim, para Mele "intenções são estados executivos cuja função primária é pôr o mundo em conformidade com planos incorporadosem-intenções" (1992, p. 162).

\subsection{Motivações}

Intenções são fundamentais para a explicação de ações promovida pela TCA que Alfred Mele propõe, no entanto, é preciso mais do que compreender intenções para explicar ações. Outro elemento também tem importância crucial para a produção de ações intencionais, inclusive para a produção de intenções: as motivações para agir, ${ }^{26}$ que participam causalmente da produção de ações, exercendo forte influência no comportamento e

\footnotetext{
${ }^{26}$ Mele não define o que é motivação em vista da variedade de acepções em que o termo é usado na literatura; portanto, ele situa a sua concepção como sendo compatível com as seguintes asserções sobre motivações: "1. Motivação está presente no reino animal, mas não se estende por todo ele. 2. Seres motivados têm capacidade de representar objetivos e de representar meios para alcançar objetivos. 3. Uma atitude que englobe-motivação pode ter um objetivo ou um meio como objeto. 4. Motivações variam em força. 5. Quanto mais forte a motivação de um agente para fazer A, em comparação com a motivação do agente para cursos de ação alternativos, é mais provável que o agente faça A, outras coisas sendo iguais. 6. Quando quer que agentes ajam intencionalmente, há algo que eles estão efetivamente motivados a fazer" (MELE, 2003, p. 03). Assim, um critério popular da psicologia motivacional para atribuir motivações é usado nessa discussão: o que distingue as espécies capazes de comportamento motivado é a flexibilidade de comportamento que a motivação lhes proporciona.
} 
que, por isso, também são fundamentais para a produção de ações humanas. Desejos são motivações no sentido que desejos são um dos tipos de estados mentais que englobam motivação (outro tipo são as intenções, por exemplo).

Mele procura explicar a relevância das motivações para ações, mostrando que um agente tem motivação, ou está motivado a agir de certa maneira, A, quando ele tem algum estado mental que englobe motivação para fazer A no momento; i.e., ele tem uma atitude motivacional. Estar motivado a agir, normalmente envolve que o agente tenha um objetivo que o levaria a mudar de comportamento em prol de alcança-lo, e que o agente quer algo (embora desejos não sejam os únicos estados mentais que englobem motivação).

Mele considera importante desenvolver um princípio para explicar ações intencionais que as relacione com a força de motivação das atitudes que englobam motivação. Essa explicação não considera que os agentes sejam subjugados ao seu desejo mais forte (mesmo se for aceita uma perspectiva de mundo determinista), deixando assim espaço para que um agente esteja mais motivado a fazer $\mathrm{A}$ e não necessariamente faça $\mathrm{A}$, se ele agir intencionalmente no momento.

A perspectiva motivacional da explicação de ações intencionais defendida por Mele está de acordo com a Perspectiva-P (vide a seção 3.1). Assim, um desejo de fazer A é uma inclinação para fazer A, e a força da motivação desse desejo não é o mesmo que sua violência ou intensidade fenomenal. Mele acredita que um agente pode ter um desejo intenso, mas motivacionalmente fraco, de fazer algo que julga contra os seus princípios; por exemplo, Márcio está prestes a perder a paciência com seus vizinhos que estão dando uma festa muito barulhenta tarde da noite. Márcio tem o desejo intenso de it até lá e gritar impropérios, mas a motivação desse desejo é fraca, ele dificilmente o faria, embora esteja irritado.

Assim, Mele propõe o princípio: $M u b^{*}$, que explica ações intencionais. ${ }^{27}$

$M u b^{*}$. Pressupondo motivações não tendenciosas, (1) se, em $t$, um agente que está fazendo A intencionalmente tem uma motivação próxima, não desbancada, focada em continuar fazendo A, que seja mais forte do que qualquer motivação que ele tenha que seja focada em qualquer outro curso de ação e do que qualquer outra motivação relevante que ele tenha para não agir, ele continua a fazer A (possivelmente apenas por um curto período de tempo), dado que ele continue a agir intencionalmente, e (2) se, em $t$, um agente que ainda não esteja fazendo $\mathrm{A}$ tem motivação próxima não desbancada focada em A mais forte do que qualquer motivação que ele tenha focada em qualquer curso de ação e do que qualquer motivação relevante que ele tenha para não agir, ele intencionalmente começa a fazer $\mathrm{A}$ em

\footnotetext{
${ }^{27}$ Mele (2003) também propõe um princípio, $M u b c$, para explicar ações intencionais simultâneas, mas esse não será apresentado aqui.
} 
breve, dado que ele intencionalmente comece a fazer alguma coisa em breve e nenhuma motivação próxima não desbancada concorrente que seja mais forte emerja em $t$ para impedir que ele faça A intencionalmente (MELE, 2003, p. 187).

Por exemplo, Diego está varrendo seu quarto e está motivado a continuar varrendo seu quarto, pois ele não tem nenhuma motivação mais forte no momento que concorra com a sua motivação para varrer, isto é, sua motivação de continuar varrendo não é desbancada. A cada 3 dias, Diego se sente motivado a varrer seu quarto por causa de uma série de fatores psicológicos relacionados ao tipo de pessoa que ele é; ele não é habituado à sujeira, ele é perfeccionista, ele é alérgico a poeira, etc. Ademais, a motivação de Diego não é afetada por nenhum fator externo que tenha criado uma tendência [bias] que a impossibilite, isto é, não foi implantado nenhum chip alienígena desfavorável à limpeza em seu corpo, nenhum neurocirurgião alterou suas conexões neurais de modo a desfavorecer essa motivação, etc.; de modo que não há motivações tendenciosas interferindo na produção de sua ação.

Sendo assim, de acordo com $M u b^{*}$, supomos que Diego vai continuar varrendo seu quarto, pelo menos pelos próximos momentos, se ele continuar fazendo algo (agindo) intencionalmente. Igualmente, pressupondo não haver motivações tendenciosas, se Diego tem motivação não desbancada para varrer seu quarto, de acordo com $M u b^{*}$, se ele faz alguma coisa intencionalmente, então ele varre seu quarto.

O contexto das motivações ajuda esse tipo de explicação ao mostrar porque o agente estava mais motivado a empreender um curso de ação do que a empreender outro. E, muitas vezes, a forma como ele julga os objetos de seu desejo- por exemplo, fazer A e fazer Binfluencia no balanço dessas motivações. O julgamento prático a respeito de qual seria o melhor curso de ação, porém, não é o único fator a determinar qual motivação prevalece. Apesar de o julgamento contribuir para a razão pela qual o agente age como ele concebe os objetos desejados influencia o seu julgamento dos mesmos e, provavelmente, as suas forças de motivação. Finalmente, é mais provável que o agente adquira uma intenção pertinente à sua motivação mais forte, a não ser que essa intenção seja desbancada pela motivação por algum outro curso de ação, ou que o agente exerça o seu autocontrole. ${ }^{28}$

\footnotetext{
${ }^{28}$ A discussão a respeito do autocontrole na Teoria da Ação é uma discussão demasiado extensa para ser abordada nesse capítulo, mas o autocontrole é uma possibilidade aberta ao agente em muitas situações, mesmo frente a sua motivação mais forte no momento.
} 


\section{Considerações Finais}

Assim, no presente capítulo foram vistas as distinções entre explicações de ações nas diferentes CA, e as distinções em relação às TCA. Ademais, foi explicitado como, a partir dessas teorias e de seus contextos conceituais surge a objeção do DA, posto pela CA para a TCA. Vistas essas duas tradições da filosofia da ação, podemos avançar na discussão sobre o papel do agente na produção das suas ações em busca de uma solução para o problema do DA. $^{29}$

29 Um capítulo a respeito da interação da discussão da Filosofia da Ação com os dados empíricos trazidos pela neurociência foi suprimido, mas pode ser encontrado em: MARQUES, B. S. Different kinds of decisions and an experiment on unconscious generation of free decisions: a conceptual analysis. Revista Unisinos, v. 16 , n. 1, p. 44-57, 2015. 


\section{Capítulo II - Oposição à Teoria Casual da Ação: Daniel Wegner e a Ilusão da Intenção}

\section{O problema da vontade consciente segundo Daniel Wegner}

Wegner consagra seu livro, The Illusion of Conscious Will, à refutação da existência de uma vontade consciente e do papel que essa teria na produção de ações. Sua principal preocupação é mostrar que aquilo que, de modo geral, as pessoas consideram a causa de suas ações não passa de um equívoco de interpretação, de uma ilusão.

Apoiando-se em vários experimentos de neurociência e psicologia, Wegner defende sua tese de que a consciência não teria um papel causal relevante nas ações dos indivíduos; ao contrário, essas seriam produzidas por atividades cerebrais não conscientes na sua maior parte. Para tanto, o autor descreve vários casos de automatismo, ${ }^{30}$ hipnose e síndrome da mão alienígena, nos quais o agente age, mas não tem consciência de que agiu muito menos das causas de sua ação.

Assim, Wegner defende que a consciência da qual temos experiência em muitas de nossas ações não passa de um adendo, acrescido às ações com o objetivo de informar ao sistema o que está sendo feito, mas que em nada contribui para a produção da ação. Aliás, segundo Wegner, a consciência da ação não acompanharia essa produção, ela provavelmente surgiria numa etapa posterior.

A vontade consciente é, então, o foco da discussão de Wegner (2002, 2008). A noção de vontade tem tradicionalmente duas acepções distintas (p. 03): uma é compreendida como sendo um estado mental consciente que é a causa da ação e a outra como sendo a experiência consciente de agir, ou de ter agido, voluntariamente. Em ambos os casos a consciência seria uma característica marcante. Porém, Wegner defende que a vontade como causa não passa de uma ilusão, enquanto que a experiência consciente da ação é real e a experimentamos

\footnotetext{
${ }^{30}$ Automatismo é uma ação voluntária que o agente empreende sem ter a experiência da vontade consciente, mas que também pode incluir a falta de consciência da ação que empreendeu e até de que foi o autor da ação (p. 99). Automatismos são normalmente vistos como casos aberrantes, pois, embora não seja incomum que um agente empreenda uma ação sem ter a experiência consciente de tê-la empreendido, é incomum que ele negue ter sido o agente da ação. Alguns casos de automatismo chagam a esse ponto de dissociação do agente com sua ação, sendo alguns casos mais comuns e outros extraordinários.
} 
cotidianamente. A confusão estaria em supor que essa experiência tem alguma relação com a produção causal das ações.

Sendo assim, não seria necessária a participação de estados conscientes na produção causal das ações. O autor chega a rejeitar que intenções possam fazer parte desse processo por considerá-las estados mentais conscientes $(2002$, p. 18) e, portanto, ineficientes; já que muitas ações não envolvem consciência do que se faz, pelo menos durante a sua produção, como no caso daquelas que Wegner chama de automatismos.

A ilusão de que estados conscientes, como a vontade, seriam a causa da ação, partiria de uma concepção equivocada da agência humana, que, segundo Wegner, seria idealizada e envolveria o emprego da consciência como um tipo de gerenciadora das ações. De acordo com Wegner, as pessoas concebem que ser um agente envolveria ser um tipo de entidade capaz de afetar o mundo a partir do comando da sua consciência, por meio da vontade ou outro estado mental afim (2002, p. 15). Assim, é essa concepção da participação da consciência na produção das ações que Wegner rejeita.

Neste Capítulo, a teoria de Wegner será discutida, especialmente a sua concepção de intenções, a suposta ilusão da participação de estados consciente na produção de ações e problemas para essa teoria. Essa discussão é relevante porque, como veremos, a teoria de Wegner acarreta numa nova formulação do problema do Desaparecimento do Agente (DA). Na seção 1, o problema discutido por Wegner e a teoria proposta pelo autor serão esboçados. Na seção 2, será explicado como essa teoria implica numa nova formulação do DA do agente. Na seção 3, os alicerces da teoria de Wegner serão analisados. Finalmente, na seção 4, esses alicerces serão questionados, e serão apresentados argumentos para rejeitá-los.

\subsection{Teoria da Causalidade Aparente}

Como às vezes ocorre de vir à mente o pensamento sobre a ação ${ }^{31}$ que vai ser empreendida imediatamente em seguida, Wegner sugere que isso leva as pessoas a desenvolverem uma interpretação de como elas agem, em que esse pensamento figura como a causa da ação. Nesse sentido, o autor associa pensamentos à consciência e um pensamento

\footnotetext{
${ }^{31}$ Wegner não chega a definir ações segundo sua própria concepção, mas em seu livro, o autor leva a crer que concebe ações como eventos que ocorrem e que devem ser causadas por eventos prévios (p. IX). A descrição que Wegner faz dos experimentos de Penfield também levam a crer que Wegner considera ações com sendo movimentos corporais causados pela atividade cerebral (p. 47).
} 
sobre uma ação, é o que Wegner chama de intenção (2002, p. 18), pois dão ao agente a impressão de compeli-lo à ação. Nota-se que essa concepção de intenção se distingue daquela defendida pela Teoria Causal da Ação (TCA) de Mele (1992, 2003).

A interpretação do agente de que sua intenção é a causa da ação geraria a experiência da vontade consciente; entretanto, Wegner defende que essa interpretação é uma ilusão, e isso o leva a rejeitar o papel da intenção na produção causal de ações.

A experiência da vontade poderia ser um resultado do mesmo processo mental que as pessoas usam na percepção mais geral da causalidade. A teoria da causalidade aparente, então, é essa: Pessoas têm experiência da vontade consciente quando elas interpretam o seu próprio pensamento como a causa da ação (Wegner and Wheatley 1999). Isso significa que as pessoas têm a experiência da vontade consciente independentemente de qualquer conexão causal real entre os seus pensamentos e suas ações. (WEGNER, 2002, p. 64)

O argumento é que: (1) as pessoas têm o hábito de impor relações causais aos eventos - nesse sentido, Wegner concorda com Hume - de modo que elas esperam que todo evento, normalmente, tenha uma causa; (2) as ações são vistas do mesmo modo que qualquer outra ocorrência no mundo, isto é, elas têm causas que as precedem temporalmente (a precedência temporal faz parte da concepção comum de causa); assim (3) o estado interno do agente que normalmente precede as ações e aparece na consciência, a intenção, é interpretado como sendo sua causa. Essa interpretação promove no agente a experiência da vontade consciente (ou experiência de ter agido); assim, a última não passaria de uma interpretação equivocada a respeito da causa da ação como sendo essencialmente consciente.

Esse argumento tem um contexto: seu pano de fundo seria a ideia de que pessoas esperam que elas conscientemente causem suas ações, visto que esse é o ideal de agência no qual, segundo Wegner, elas acreditam se encaixar. De acordo com a teoria da causalidade aparente, intenções, crenças, desejos, etc, seriam pensamentos conscientes do agente sobre a ação que dão origem à experiência da vontade consciente, ou seja, a experiência de ter agido por causa da sua vontade consciente (a partir daqui sempre que for usado o termo resumido experiência de ter agido, o leitor deve compreender que se trata dessa experiência), quando interpretados pelo agente como sendo causa da ação. Segundo Wegner, essa interpretação é uma ilusão.

Essa experiência que segue dos pensamentos sobre a ação geraria a ilusão de que esses pensamentos conscientes causaram a ação e é isso que Wegner chama de ilusão da vontade, pois a associação dos pensamentos conscientes à causa da ação dá a impressão de que a 
consciência tem um papel imprescindível na produção das ações humanas. A tese do autor é que, justamente, a consciência não tem efetivamente esse papel.

Linha do tempo ${ }^{32}$

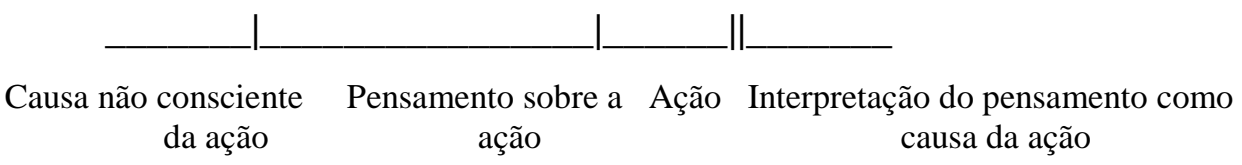

Esses pensamentos seriam causados, segundo Wegner, por processos mentais não conscientes, talvez processos diferentes daqueles que causam a ação ela mesma:

Nesse sistema, processos mentais inconscientes dão origem a pensamentos conscientes sobre a ação (e.g., intenção, crença), e outros processos mentais inconscientes dão origem à ação voluntária. Pode ou não haver ligações entre esses sistemas inconscientes subjacentes (como designado pelo caminho bidirecional inconsciente em potencial), mas isso é irrelevante para a percepção do aparente caminho do pensamento consciente para a ação (WEGNER, 2002, 67)

Nesse contexto, os pensamentos conscientes sobre a ação têm uma causa, Wegner sugere que essa seria um processo não consciente e que esse processo não é a causa efetiva das ações. Efetivamente, a causa das ações seria outro processo não consciente e independente do primeiro. Assim, os pensamentos conscientes e suas causas não teriam relação com a produção causal da ação, apenas com a consciência das ações. O papel de causa das ações seria desempenhado por outro processo não consciente.

A ilusão produzida pelo aparecimento do pensamento sobre a ação logo antes da ação tem três fontes, segundo o autor: a) a antecedência temporal do pensamento, isto é, ele surge $\operatorname{logo}$ antes da ação; b) a consistência do pensamento com a ação, ou seja, há uma correspondência entre o conteúdo do pensamento e a ação realmente efetuada; e c) a exclusividade causal desse pensamento, isto é, ele aparenta ser a única causa da ação.

Quando uma dessas três fontes da ilusão está ausente, Wegner acredita que isso compromete a aparência de causalidade do pensamento consciente. Alguma dessas estaria, então, ausente nos automatismos, na hipnose e na síndrome da mão alienígena. Todavia, não apenas nesses exemplos atípicos; para o autor, há outras ações, mais cotidianas, nas quais o agente não tem a experiência consciente de ter agido, nem de que a ação foi sua.

\footnotetext{
${ }^{32}$ Essa linha do tempo não pretende mostrar o tempo exato em que cada um dos eventos representados ocorre, ela visa apenas ilustrar a relação de tempo entre eles; isto é, qual deles ocorre primeiro, segundo, etc.
} 
Com efeito, o autor não quer dizer que a vontade consciente, isto é, que a experiência consciente de ter agido que surge da interpretação do pensamento como causa da ação, seja inútil. Afinal, se temos essa experiência cotidianamente, faz sentido supor que ela tenha alguma função, que não seja a de nos iludir. Wegner sugere que sua função seria indicar que a mente está causando a ação:

Contudo, se a vontade consciente é uma experiência que surge da interpretação de pistas da causalidade cognitiva, então a causalidade mental aparente é gerada por um processo interpretativo que é fundamentalmente separado dos processos mecânicos da causalidade mental real. A experiência da vontade pode ser uma indicação de que a mente está causando a ação, especialmente se a pessoa for um bom interpretador de si, mas não é conclusiva. (WEGNER, 2002, p. 96)

Assim, a experiência de ter agido seria produzida por um mecanismo diferente daquele que produz a ação. Essa hipótese da independência de mecanismos subjacentes permitiria perceber um equívoco na interpretação de que um estado mental conscientemente causaria a ação. Pois Wegner defende que a evidência para essa interpretação seria extraída da experiência de ter agido, que nada teria a ver com a produção causal da ação; dado que a última seria produzida por um mecanismo diferente. De acordo com essa tese, a experiência de ser o autor da ação teria a função de informar o que está acontecendo no sistema, não consciente, e o que será feito.

A experiência da vontade, então, é o modo pelo qual nossas mentes retratam suas operações para nós, não efetivamente a sua operação. Porque temos pensamentos sobre o que vamos fazer, nós podemos desenvolver teorias causais relacionando esses pensamentos às nossas ações com base na prioridade, consistência e exclusividade. Nós chegamos a pensar nesses pensamentos prévios como intenções, e nós desenvolvemos a sensação de que intenções têm força causal mesmo elas sendo apenas prévias [previews] do que poderemos fazer. No entanto, num sentido importante, deve ser o caso que algo em nossas mentes desempenhe um papel causal em fazer as nossas ações ocorrerem. Esse algo é, na teoria da causalidade aparente, um conjunto de processos mentais inconscientes que causam a ação. Ao mesmo tempo, esse algo é muito parecido com os pensamentos que temos antes da ação. (WEGNER, 2002, p. 96)

Os pensamentos sobre a ação aos quais Wegner se refere nessa passagem são os pensamentos conscientes que antecedem a ação, dentre os quais a intenção estaria inclusa, mas que não teriam nenhuma relevância causal efetiva para a produção da ação. 
Devemos nos lembrar que essa análise sugere que os verdadeiros mecanismos causais subjacentes ao comportamento não estão nunca presentes na consciência. Preferencialmente, as engrenagens da causalidade operam sem se revelar para nós e podem assim ser mecanismos inconscientes da mente. Muito da pesquisa recente sugerindo um papel fundamental aos processos automáticos no comportamento cotidiano (Bargh 1997) pode ser compreendido sob essa luz. As verdadeiras causas da ação humana são inconscientes, assim não é surpreendente que um comportamento pudesse frequentemente surgir - assim como em experimentos de automatismo - sem a pessoa ter a percepção consciente da sua causalidade. (WEGNER, 2002, p. 97)

Assim, é possível perceber que a teoria apresentada por Wegner se opõe firmemente à hipótese de que ações possam ter causas conscientes, de modo que os agentes nunca estariam conscientes das causas de suas ações.

\subsection{Intenções}

Wegner apresenta uma definição incomum de intenções que sugere que elas são sempre conscientes e que, por isso mesmo, seriam frequentemente associadas à causa da ação. "Intenção é normalmente compreendida como uma ideia do que vai ser feito que aparece na consciência logo antes do agente fazê-lo. Esse é o pensamento que as pessoas geralmente associam mais fortemente com a causa da ação" (WEGNER, 2002, p. 18)

Essa seria uma concepção útil, segundo o autor, para ajudar a compreender as ações humanas; afinal, ter um objetivo que se intenciona alcançar por meio da ação é o que dá sentido a ela. E que esse objetivo seja algo que o agente deseja nos permite compreender porque ele age, "[...] não faz muito sentido atribuir a agência de uma ação a uma mente consciente que não quer algo" (WEGNER, 2002, p. 19). É curioso que Wegner aceite que objetivos que motivam o agente a agir são relevantes para suas ações, já que essa relevância só faz sentido se a motivação tiver o poder de levar o agente a agir.

Nesse contexto, o autor aceita o quadro geral da Teoria Causal da Ação (TCA), i.e., de que seríamos agentes causais (2002, p. 15); porém, ele não aceita a concepção de intenção ${ }^{33}$ proposto pelas TCA. Wegner propõe sua própria noção de intenção, diferente daquela

\footnotetext{
${ }^{33}$ Não que haja um consenso absoluto nas TCA a respeito das intenções em todos os seus aspectos; mas, de modo geral, a sua função de desencadear os mecanismos da ação e ajudar a planejar ações distantes, e a sua condição de satisfação de que a ação seja empreendida por causa da intenção são bem aceitas.
} 
normalmente apresentada pela TCA e, com base nessa concepção própria, o autor rejeita o papel que as TCA atribuem à intenção na ação; contudo, ele está fazendo uso do termo em outro sentido. No sentido que Wegner atribui a intenções, as TCA provavelmente também não lhe confeririam um papel relevante na produção causal das ações. Assim, o que Wegner chama de intenção é diferente do que as TCA normalmente chamam de intenção. Wegner trata de outra concepção de intenção.

Wegner aceita que, no caso das intenções para agir no futuro, essas não são necessariamente conscientes no momento em que compelem à ação. Provavelmente o autor aceita a ausência da consciência nesses casos porque ela já teria participado da produção da intenção prévia, o que leva a crer que essa noção de intenção consciente é a fonte da concepção de que a ação provém da vontade consciente. Pois, segundo essa compreensão, a consciência participaria da produção de toda intenção em algum momento.

Intenções que ocorrem logo antes da ação, em contraste, parecem compelir à ação. Esse é o fenômeno básico da experiência da vontade. Em toda língua, claro, uma ação é frequentemente descrita como intencional quando é conscientemente planejada (e nós não precisamos estar conscientes dela quando a empreendemos) ou quando nós conscientemente percebemos empreendê-la quando a empreendemos. (e pode não ter sido planejado antecipadamente). (WEGNER, 2002, p. 20)

Contudo, não é um consenso que a consciência da intenção seja uma condição necessária para que uma ação seja intencional (MELE, 2009, p. 39). Assim, segundo a teoria de Mele (2009), não faz parte da definição de intenções que elas sejam necessariamente conscientes, nem essa é uma condição necessária para as ações intencionais. Para Wegner, no entanto, intenções imediatas, isto é, para agir imediatamente, são sempre conscientes:

Todos esses conteúdos mentais parecem acompanhar e apoiar que a agência causal nos seres humanos não precisa ser consciente no momento da ação. Ao invés, parece que apenas a intenção precisa aparecer na consciência no momento em que agimos, ao passo que as crenças, desejos e planos que podem servir como o andaime para a intenção não precisam estar na consciência. (WEGNER, 2002, p. 20)

Assim, intenções são, para o autor, os pensamentos que surgem na consciência a partir de processos não conscientes, sendo assim o estado mental por meio do qual o agente toma consciência da produção das suas ações. Nesse sentido, esses estados mentais seriam produzidos pelo processo em questão, de modo que eles não teriam qualquer relevância causal 
para a produção da ação. Entretanto, intenções não seriam um epifenômeno, pois Wegner lhes atribui a função de informar ao agente o que ele vai fazer.

O autor defende que (1) intenções são conscientes; (2) nem sempre o agente tem consciência do que faz - por exemplo, nos casos de automatismo - nem tem consciência da causa da sua ação; assim, (3) intenções, que são estados conscientes, não são a causa de todas as ações.

O argumento que Wegner está propondo (p. 143-144) é de fato o seguinte: já que não há consciência por parte do agente em algumas ações, pelo menos dessas as intenções não participariam; a verdadeira questão é que, se intenções não causam todas as ações humanas, então, talvez não causem nenhuma. Ora, é mais simples supor que todas as ações humanas, automatismos ou não, tenham o mesmo tipo de causa. Como o que as ações humanas têm em comum são os processos cerebrais não conscientes, estes seriam as verdadeiras causas das ações, nesse sentido, um estado mental necessariamente consciente não é um bom candidato ao papel de causar ações. Assim, Wegner rejeita que intenções, como ele as concebe, façam parte das causas das ações humanas.

\subsection{Controvérsia a respeito das intenções}

A aquisição de uma intenção e sua participação na produção da ação pode às vezes sêlo, mas não precisa ser consciente, pois a atenção do agente não está sempre voltada para ela; por isso, a intenção nem sempre emerge para se tornar consciente. A atividade cerebral que, numa dada circunstância, realiza um desejo de fazer A, pode acontecer paralela a outras atividades para as quais a atenção está voltada, e a resolução de executar o plano para a ação B, isto é, a atividade cerebral que realiza a intenção de fazer A, pode acontecer da mesma forma. De modo que a ativação dos mecanismos de execução da ação pode acontecer antes do agente estar consciente de que está executando a ação.

Nesse sentido, estados conscientes não necessariamente participam da produção causal de ações e o agente não precisa estar sempre consciente de todos os seus desejos, intenções, nem da ativação dos mecanismos que levam às ações. Geralmente os agentes estão conscientes daquilo que estão fazendo, apesar de haver exceções mesmo quanto a isso. Por 
exemplo, a moça que está sentada na mesa ao lado pode não estar consciente de que ela está batendo os seus dedos na mesa repetidamente.

Intenções podem ser adquiridas passivamente, segundo Mele, o que ajuda a explicar ações súbitas e impulsivas. Os casos de automatismo se encaixam bem nessa explicação, pois são ações que não deixam de envolver intenções, no caso, não-conscientes, ${ }^{34}$ mas que, em casos extremos envolvem autoengano por parte do agente. $\mathrm{O}$ autoengano e as pressões sociais ajudariam a criar esse fenômeno que fascina Wegner.

Há duas formas distintas de um agente vir a ter uma intenção de agir, de acordo com Mele. A primeira é por meio de uma decisão, que já seria uma ação, a ação de formar ativamente uma intenção; e a segunda é por meio da aquisição passiva de uma intenção em decorrência das motivações que o agente tem no momento. Mele sugere que os seres humanos estão dispostos a adquirir (ou formar) intenções de acordo com o julgamento resultante de uma inferência prática e isso explicaria a sua aquisição.

Intenções podem resultar da reação emocional do agente em relação à sua percepção e interpretação do mundo, de modo que essa reação o incline a fazer A, que seria aquilo que ele deseja mais fazer no momento. E a intenção já é o primeiro passo da execução, pois adquirir uma intenção é começar a agir, visto que envolve a resolução de agir que compromete o agente à ação.

E quando são conscientes Mele (2009) propõe que o seu papel causal não é desempenhado em função de ser consciente, mas em função dos mesmos realizadores físicos que a realizariam quando ela não é consciente e os realizadores físicos da consciência da intenção podem não ter nada a ver com os primeiros. O que poderia ser considerado um ponto de acordo com Wegner, dependendo de como se compreende intenções.

Intenções podem ser distais, como sugere Mele (2009); por exemplo, eu tenho a intenção de almoçar hoje, perto do meio dia, porém, se eu me mantiver constantemente consciente dessa intenção, sem dúvida eu conseguirei trabalhar bem pouco nessa manhã. Ao contrário do que Wegner sugere, a teoria causal das ações propõe que nem todas as intenções são conscientes. Contudo, creio que o autor está mais interessado nas intenções próximas, isto é, para agir imediatamente.

\footnotetext{
${ }^{34}$ Nos casos em que não estou me referindo à teoria de Wegner, eu prefiro o termo não-consciente ao invés de inconsciente. Justifico essa preferência porque, ao contrário de Wegner, eu considero que os estado mentais envolvidos na produção da ação, mesmo que não sejam conscientes no momento dessa produção, poderiam sêlo. Veja o Capítulo III para uma discussão mais aprofundada a respeito de como esses estados mentais poderiam ser conscientes na produção de algumas ações.
} 
Mele se apoia nos exemplos apontados por Anthony Marcel em Sense of Agency: Awareness and Owneship of Action (2003), nesse texto Marcel exemplifica algumas situações em que é possível conceber que o agente não está ciente da sua intenção, apesar de agir de acordo com ela. (1) Ele cita casos em que o agente tem a intenção de agir, mas não está ciente de como empreenderá a ação em questão, isto é, qual é o procedimento escolhido. Por exemplo, quando um agente vai fechar a porta da geladeira, ele não está ciente se vai usar a mão ou o quadril. Ou, ao pegar algo no alto do armário, o agente não está ciente da sua intenção de subir em cima de um banquinho.

(2) Há situações em que o agente se esquece de seu objetivo geral enquanto está ciente apenas de um subobjetivo, por exemplo, quando uma mãe chama o seu filho, mas sem se dar conta exatamente do que ela pretende falar com ele. (3) Além disso, há um tipo de erro na fala, cuja melhor explicação, segundo Marcel, seria a existência de uma intenção não consciente para executar um plano de fala ao mesmo tempo em que o agente tem uma intenção consciente concorrente relativa a um plano diferente. Essa intenção não consciente emerge quando há uma equivalência fonológica num ponto de equivalência estrutural na fala, o que para Marcel é uma evidência da existência de intenções não conscientes. (4) Intenções a longo prazo nem sempre são conscientes, como a intenção de ser apreciado ou de manter a autoestima. (5) Finalmente, Marcel cita situações em que o agente está imerso numa ação contínua, de modo que ele tem a sensação de estar agindo intencionalmente, mas não tem ciência de cada uma das suas intenções; por exemplo, um jogador de tênis já tem uma intenção ao se preparar para rebater a bola, apesar de ele ainda não estar ciente de qual jogada executará.

Nesse sentido Mele aponta que a definição apresentada por Wegner de intenções, que é uma ideia que vem à mente antes da ação, não é uma boa definição para intenções, pois não fornece uma condição suficiente para que algo seja uma intenção. Mele (2009) exemplifica com o caso de um motorista que percebe que vai colidir com outro automóvel e, logo antes da colisão, a ideia de que ele vai bater lhe vem à mente; contudo, essa é uma previsão e não uma intenção. Sendo assim, segundo o autor, a concepção de Wegner de intenções estaria equivocada, pois intenções não precisam ser uma produção da consciência, nem precisam ser acompanhadas da consciência da intenção.

Como o próprio Wegner sugere, a causa da ação é uma coisa, outra coisa diferente é a experiência de ter agido. Mele (2009) também lembra que uma coisa é uma intenção, outra é a experiência dessa intenção. A experiência de estar agindo, de ter agido ou de ter tido a 
intenção de agir podem surgir posteriormente à ação, mas isso não diz nada sobre a causa da ação nem sobre a intenção de agir.

Se, como Marcel (2003) mantém, intenções próximas não-conscientes podem produzir ações intencionais correspondentes, a intenção próxima consciente de um agente para flexionar pode produzir a ação de flexionar de modo que não dependa de ela ser uma intenção consciente. Se muitas intenções próximas produzem ações sem as intenções aparecerem na consciência, isso não é um resultado terrivelmente surpreendente. (MELE, 2009, p. 34)

Mele também defende que não é necessário que o agente esteja consciente de que ele tem a intenção de agir para que essa tenha um papel causal na ação. A intenção não precisaria ser concebida como um estágio de "eu vou fazer isso" (2002, p. 130) consciente, como sugere Wegner.

(Q2) Devo eu estar ciente (ou consciente) de que eu tenho a intenção de fazer $A$ para que a minha intenção de fazer $A$ ou seu correlato físico desempenhe um papel significativo na produção de uma ação $A$ intencional? Um agente estar ciente de que ele tem a intenção de fazer $A$ acarreta que ele tenha um conceito de intenção. Alguém que não tem qualquer conceito de paradoxo ou de nota falsa de dólar - digamos, uma criança normal de dois anos - não pode estar ciente de que sua mãe acaba de descrever um paradoxo para a sua irmã ou de que está segurando uma nota falsa. Semelhantemente, alguém que não tenha o conceito de intenção - talvez a mesma criança - não pode estar ciente de que ele tem a intenção de fazer $A$. (MELE, 2002, p.23)

O que não impede que a criança tenha uma nota falsa nem que ela tenha uma intenção, apenas porque não sabe ainda o que são nenhuma das duas. Afinal, nessa acepção, uma intenção não apareceria necessariamente na consciência como um "eu farei A", ao contrário do que sugere Wegner.

Para Wegner o processo que causa a ação teria que ser inconsciente, ${ }^{35}$ o que leva a perguntar como intenções poderiam às vezes ser conscientes e outras não? Qual seria a diferença entre esses dois estados? E como é possível que a consciência da intenção não faça diferença na sua eficiência causal? Ao que parece essas são as questões relevantes trazidas à tona pela discussão de Wegner e Mele. Essas perguntas serão respondidas no capítulo III.

Apenas uma concepção de intenções que respondesse essas perguntas poderia estar fora do alcance das críticas de Wegner à suposta participação da consciência nas teorias que

\footnotetext{
${ }^{35}$ Wegner usa o termo unconscious que eu traduzirei aqui como inconsciente.
} 
envolvem intenções nas explicações de ações. Ao mesmo tempo, tal concepção de intenções poderia ser considerada mais atraente do que a concepção de ideias de ação como causa das ações, pois poderia abranger casos não apenas focados em automatismos, como também ações das quais o agente tem consciência.

\section{O agente}

Nessa seção serão discutidas as implicações da teoria de Wegner para o DA. Wegner defende que a vontade consciente é uma ilusão, mas não só ela. Para o autor, a impressão de que temos mentes, de que somos selves, de que somos agentes e de que causamos o que fazemos é uma ilusão:

O fato é, parece a cada um de nós que temos vontade consciente. Parece que somos selves. Parece que temos mentes. Parece que somos agentes. Parece que causamos o que fazemos. Embora seja decepcionante e, por fim, correto chamar tudo isso de ilusão, é um erro concluir que a ilusão seja trivial. (WEGNER, 2002, p. 341)

Essas ilusões são, segundo Wegner, extremamente úteis, pois a ilusão da causalidade mental é o fundamento da psicologia e da vida social humana, e essas ilusões nos dão o nosso sentimento de individualidade e de responsabilidade moral.

Não pretendo discutir se os seres humanos são selves ou se têm mentes, o que me surpreende é a afirmação de Wegner de que seres humanos não são agentes. Podemos supor que ele queira dizer que não somos agentes cuja consciência produziria suas ações. Pois Wegner define (p. 16-17) o que ele chama de agentes causais com base na concepção do senso comum, segundo a qual, agentes são entidades que buscam alcançar objetivos e cujas

ações compreendemos em vista dos objetivos que buscam, e não dos eventos que a antecederam (como normalmente entendemos os seres inanimados). No caso dos seres humanos a consciência lhes permitiria vislumbrar a sua própria agência causal.

\subsection{Paralelo: zumbi interno e desaparecimento do agente}


As ações que são empreendidas sem a consciência do agente ao longo do seu processo de produção, e talvez até mesmo as que contam com a consciência do agente, segundo a teoria de Wegner, são consideradas como não tendo sido empreendidas pelo próprio agente ${ }^{36}$ e até como algo alheio a ele, como se não fossem suas ações.

A forma como Wegner afirma que não somos agentes e não causamos o que fazemos sugere que não participamos das nossas ações. Por conta das suas causas não serem sempre conscientes, nem as próprias ações, que muitas vezes podem também não ser conscientes. Da forma como Wegner a apresenta, parece que todas as ações são quase tão alheias quanto o movimento do pêndulo de Chevreul, ${ }^{37}$ como se o agente pudesse até se surpreender com sua ação.

Para Wegner é como se fôssemos zumbis, ou como se houvesse um lado zumbi em nós, que é efetivamente a causa de nossas ações. E esse lado não teria relação com a parte consciente de nós. Esse tipo de concepção é um paralelo à ideia de que a TCA supostamente constrói um cenário em que eventos acontecem sem nenhuma participação do agente: o problema do DA. No caso da teoria de Wegner, o próprio autor propõe algo semelhante: a produção das ações por um zumbi interno. Poder-se-ia perguntar a Wegner quem age se não o agente?

É estranho pensar que a atividade cerebral que não é consciente esteja dissociada da pessoa na qual ela ocorre, ou que não esteja estreitamente ligada à parte consciente dessa atividade. Ainda mais se for realmente o caso que a atividade não consciente é a maior parte da atividade cerebral dos seres humanos (Wegner, 2002).

\section{Vontade consciente}

Questões filosóficas a respeito da vontade consciente e seu papel na produção de ação passaram nas últimas décadas a ter lugar nas investigações da neurociência, incluindo perguntas sobre a liberdade humana. Uma das discussões mais famosas sobre a vontade

\footnotetext{
${ }^{36}$ Agente aqui compreendido no sentido que Wegner confere ao termo.

${ }^{37}$ Uso de um pêndulo que se acreditava que, dependendo do seu movimento, oferecia informações de forma sobrenatural.
} 
consciente foi provocada pelo experimento de Benjamin Libet $(1983$, 1985), que pretenderam mostrar que a vontade consciente não inicia as ações humanas.

Apesar do grande interesse nessas questões, na verdade, pouco se sabe sobre o papel da chamada vontade consciente na produção das ações humanas. Alguns experimentos nos deram peças do quebra-cabeça, mas não produziram um consenso sobre o assunto. Em The Illusion of Conscious Will (2002), Daniel Wegner tem como objetivo contribuir para o debate, oferecendo uma teoria para o papel da vontade consciente na produção de ações, o que, segundo ele, seria apenas uma ilusão.

Eu discordo da teoria de Wegner e nas próximas seções eu vou explicar por que não há razão suficiente para aceitar essa chamada ilusão. Eu sugiro que há pelo menos uma outra possibilidade para explicar a consciência da produção de ações humana (vide o capítulo III). Claro, The Illusion of Conscious Will (2002) é uma investigação extensa e complexa que eu não será discutida em sua totalidade. Vou limitar esta discussão aos principais argumentos que sustentam a sua Teoria da Causalidade Mental Aparente (TCMA). Essa discussão será dividida em duas partes. Primeiro, vou discutir as razões que Wegner oferece para acreditar que esse é de fato o papel da chamada vontade consciente (seções 3.1., 3.2., 3.3.). E em segundo lugar, na seção 4, vou argumentar que estas não são razões convincentes em face de novas evidências experimentais a respeito do potencial de prontidão ${ }^{38}$ (readiness potential, RP). E, finalmente, no próximo capítulo (Capítulo III) será oferecida uma explicação alternativa para o papel da consciência na produção de nossas ações.

\subsection{A vontade consciente é uma experiência, não uma causa}

Em The Illusion of Conscious Will (2002) Daniel Wegner alega que a nossa

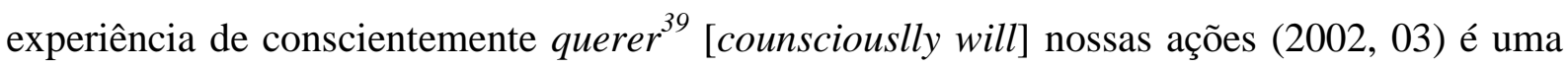
ilusão. ${ }^{40}$

\footnotetext{
${ }^{38}$ O chamado Potencial de Prontidão é uma atividade eléctrica medida no cérebro; uma mudança de potencial negativa.

${ }^{39}$ Usarei o verbo querer para traduzir to will do inglês. Apesar de querer não capturar completamente o sentido da locução verbal inglesa, eu a considero a tradução mais aproximada. O leitor deve manter em mente que querer estará aqui sendo usado no sentido de to will (a não ser que seja explicitamente dito que o termo está sendo usado em outro sentido).

${ }^{40}$ Wegner opõe a vontade consciente à vontade empírica - a causalidade dos pensamentos conscientes da pessoa, estabelecida por uma análise científica de sua covariação com o comportamento da pessoa (2002, p. 14).
} 
É comum falar sobre a vontade consciente como algo de que temos experiência quando realizamos uma ação - temos a sensação de ações querer ações ou não, e esse sentimento de voluntariedade ou de fazer uma coisa "de propósito" é uma indicação da vontade consciente. Também é comum, no entanto, falar da vontade consciente como sendo uma força da mente, um nome para a ligação causal entre nossas mentes e nossas ações. Pode-se supor que a experiência de conscientemente querer uma ação e a causação da ação pela da mente consciente da pessoa sejam a mesma coisa. Como se constata, no entanto, eles são totalmente distintas, e a tendência a confundilos é a fonte da ilusão ${ }^{41}$ da vontade consciente de que este livro é sobre. $(2002,03)$

Wegner afirma que a vontade consciente é entendida como uma experiência, tanto quanto como sendo a causa das ações, e embora ele aceite que temos essa experiência, ele argumenta que a vontade consciente não seria de fato a causa de nossas ações, nem seria a experiência correspondente a tal causa. A seguir discutiremos os principais argumentos de Wegner.

Wegner rejeita a vontade consciente considerada como uma força da mente que causaria a ação, pois isso não seria nada além de uma ilusão. No entanto, ele aceita que temos a experiência da vontade consciente, e ele argumenta que nós confundimos essa experiência com um correlato na produção causal da ação. Então, quando Wegner usa o termo vontade consciente, entendemos que ele o está usando no sentido da experiência da vontade consciente, a fim de mostrar que esta experiência não tem um correlato na produção de ação.

Como a experiência da vontade consciente é uma expressão difícil de definir, ${ }^{42}$ suporemos que pela expressão experiência de que nós conscientemente queremos nossas ações Wegner quer dizer a nossa experiência que a consciência ${ }^{43}$ (ou estados mentais

\footnotetext{
${ }^{41}$ Michael Young (2004) tem uma preocupação importante sobre este ponto: "Ao longo da minha leitura de seu livro, eu estava persistentemente incomodado com a noção de que essa ilusão poderia ser desnecessária — por que nossa espécie precisaria ter a sensação de intencionar nossas ações quando a mera consequência de nossas ações poderia servir ao propósito de selecionar as respostas adequadas para várias situações no futuro (à la Skinner)? Será que a ilusão de ter qualquer benefício para nós como uma espécie?” (YOUNG, 2004, p. 678). Wegner afirma que essa ilusão tem suas funções, tais como sinalização social, alocação social e controle social, o que ele explica em Self is Magic (2008).

${ }^{42}$ É controverso se uma coisa como a vontade existiria (O'SHAUGHNESSY, 1996). A vontade é um termo filosófico utilizado no século XVIII e XIX, e aquilo a que pode efetivamente se referir tem sido uma questão para debate. Alguns dos filósofos de inclinação naturalistas, do século XX, rejeitam a noção, embora o termo seja usado em psicologia (O’SHAUGHNESSY, 1996).

${ }^{43}$ Wegner afirma que a consciência não desempenha um papel na produção de ação, quando ele defende a ilusão da vontade consciente: "A microanálise do intervalo de tempo antes e depois da ação indica que a consciência entra e sai do quadro e realmente não parece fazer nada" (WEGNER, 2002, p. 59). Assim, parece que ele também considera que a vontade consciente signifique a inferência de que a experiência de que a consciência desempenha um papel causal na produção de ações seria a prova desse papel causal.
} 
conscientes $)^{44}$ desempenha um papel causal na produção de ações. ${ }^{45}$ Vou chamar essa experiência de Experiência do Papel da Consciência ${ }^{46}$ (EPC) para encurtar. ${ }^{47}$

\subsection{EPC é uma experiência confiável que não corresponde a uma causa de ação}

Wegner examina as duas acepções de vontade consciente: a experiência da vontade consciente (o que estou chamando EPC) e a vontade consciente considerada como a causa da ação. Sobre a experiência que ele afirma: "Ainda assim, os automatismos e ilusões de controle [...] nos lembram que ação e sensação de agir não estão inevitavelmente engatadas juntos" $(2002,11)$. Segundo Wegner, elas podem ser separadas. E uma vez que essas podem ser separadas, ele sugere que eles podem ser produzidos por sistemas separados (2002, p. 11).

(1) Não há EPC em algumas ações que o agente parece querer; por exemplo, hipnose e automatismos.

(2) Pode haver EPC quando não há nenhuma ação. Isso é o que Wegner chama ilusão de controle. ${ }^{48}$ Wegner relata que uma vez, em uma loja de brinquedos, ele viu um vídeo game e começou a mexer com o joystick. Na ocasião, ele pensou que ele estava jogando o vídeo game, mas se tratava apenas do demo pré-jogo. Quando a mensagem "iniciar o jogo" apareceu

\footnotetext{
${ }^{44}$ Vontade consciente não é uma noção muito clara. Pode ser difícil compreender o que se entende por vontade consciente, então a definição de Wegner baseará como esta noção será entendida nesta investigação. Wegner dá dois significados distintos para o termo: (1) uma força de mente que causa ações, e (2) a experiência segundo a qual temos a sensação da vontade na ação $(2002,03)$. Em (1) é pouco claro como "força da mente" deve ser entendida; a expressão faz pensar em programas de TV em que pessoas movem objetos com a força de suas mentes. E em (2) Wegner faz uso do termo vontade [willing] para explicar a vontade, de modo que não se vai muito longe. É claro, no entanto, que, para Wegner, esses são significados distintos do termo vontade consciente. Eu suspeito que Wegner endossa o primeiro significado, (1), que se refere a um tipo de experiência que temos de que estamos conscientemente fazendo com que nossas ações aconteçam na maioria das vezes que agimos, e é parte dessa experiência que a consciência da nossa conação (conação sendo aqui entendida como uma tendência para algo, ou um desejo) para agir cause a ação, ou desempenha um papel relevante na produção da ação.

${ }^{45}$ Consciência aqui deve ser entendida como consciência transitiva; i.e., consciência de algo, nesse caso, de um estado mental.

${ }^{46}$ Quando Wegner discute a ilusão por meio da qual explicamos nossas ações, ele afirma que a ilusão em que acreditamos, o que ele normalmente chama de vontade consciente, é "uma crença na eficácia causal dos nossos pensamentos conscientes" (2002, p. 27-28). E pelo pensamento consciente ele quer dizer "leia-se: a intenção, mas crença e desejo também são importantes" (2002, p 66).

${ }^{47}$ Deixamos de lado os casos de danos cerebrais—e.g. síndrome da mão alienígena—já que claramente esses são casos patológicos.

48 “[...] casos em que as pessoas têm a sensação de que estão fazendo algo quando na verdade não estão fazendo nada" (WEGNER, 2002, p. 09).
} 
na tela, ele percebeu que não estava realmente controlando os movimentos do personagem do vídeo game. Wegner considera este um caso de ilusão de controle, porque ele estava convencido de que ele estava fazendo algo que, na verdade, ele não estava fazendo.

Esses casos supostamente mostrariam que a EPC pode ser desvinculada da produção da ação. E a experiência acompanha algumas ações, enquanto que outras não. Assim, a EPC seria apenas uma experiência, não uma causa na produção de ações, porque ela não poderia ser a causa de todas as ações. Wegner, então, conclui que EPC não é confiável. (1) e (2) ajudam o argumento de Wegner, porque oferecem razões para se crer que não podemos realmente relacionam EPC com a causa de ações, e se o fazemos podemos estar enganados.

A teoria defendida por Wegner também é baseada na alegação de que a consciência, ou qualquer força consciente, não produz causalmente ações. Neste sentido, Wegner afirma que (3) inferimos que haja uma relação causal entre a experiência de vontade, EPC, e a ação por causa da constante união que percebemos entre ambos; afinal de contas, é assim que estamos habituados a inferir relações causais $(2002,13)$.

Wegner argumenta que a causalidade não é um atributo de objetos, nem é um atributo da mente, uma vez que a causalidade não é um atributo. No entanto, a nossa inferência de que há uma relação causal pode nos levar a crer que a causalidade é de fato um atributo: "assim como um prato pode ter quentura ou um automóvel pode ter a propriedade de ser vermelho, uma pessoa parece ter vontade, uma qualidade de poder que causa suas ações" (WEGNER, 2002, p. 13). Wegner está preocupado com a concepção da vontade como sendo uma força; i.e., considerada como uma propriedade ou um atributo de pessoas que causa ações; ele, no entanto, defende que "a causalidade é um evento, não uma coisa ou uma característica ou atributo de um objeto" $(2002,13) .{ }^{49}$ Assim, a experiência de vontade, EPC, não seria uma evidência da causalidade da vontade consciente $(2002$, 15), porque a causalidade não é um atributo da vontade.

Afora isso, Wegner alega que a forma como percebemos a nós mesmos contribui para a ideia de que a vontade consciente causa as nossas ações, uma vez que (4) a vontade consciente se encaixa com nossa ideia de nós mesmos como sendo agentes causais (2002, p.

\footnotetext{
49 Thomas Metzinger (2004) discorda que subsistemas, como o que Wegner chama de nós, possam fazer inferências baseadas em experiências conscientes que o agente tenha. "As leituras subpessoais são todas falaciosas: cérebros - ou subsistemas funcionais de cérebros-não interpretam coisa alguma, eles não fazem inferência alguma, e eles não exercem controle. Apenas pessoas por inteiro podem ser direcionadas para o significado de certas sentenças (ou de sentenças que descrevem cadeias de eventos internos), tentando, assim, interpretá-las. Apenas pessoas inteiras poderiam estabelecer inferências entre proposições representadas mentalmente" (METZINGER, 2004, p. 670).
} 
15). Este é o caso, porque Wegner acredita que os estados mentais que as pessoas costumam empregar para explicar as suas ações, tais como intenções, são estados mentais conscientes, mas ele rejeita que esses estados mentais conscientes possam ter um papel causal na produção de ação. ${ }^{50}$

Os argumentos de Wegner visam mostrar que a EPC não causa as ações humanas; a EPC apenas produziria a ilusão de sua eficácia causal. No entanto, estes argumentos, especialmente (1) e (2), no máximo, demonstrar que é possível que a EPC seja produzida separadamente da produção de ações. No entanto, esses argumentos ainda não fornecem razões para acreditar que essa experiência realmente seja produzida separadamente. Wegner está ciente disso, pois ele prossegue desenvolvendo argumentos para mostrar que a EPC é realmente produzida separadamente da produção de ações.

\subsection{Onde e quando de EPC}

Os argumentos de Wegner de que há um equívoco a respeito da EPC causar ações mostra que a questão principal seria se a sensação de agir (2002, 29 p.) é uma inferência que fazemos sobre nós mesmos ou uma experiência de um evento causal real. Wegner ofereceu algumas razões para se crer que é possível interpretar a EPC como sendo uma inferência, mas Wegner acredita que é possível mostrar que essa é mais do que uma mera possibilidade. Podese mostrar que a EPC na verdade é apenas uma inferência investigando onde e quando surge a nossa sensação de agir. Isso deve tornar claras as circunstâncias em que temos a EPC. Portanto, localizar a EPC se torna um passo importante que irá (1) mostrar que essa experiência é algo separado dos mecanismos reais que produzem ações, e (2) provar que a EPC corresponde apenas a uma inferência que fazemos sobre a produção de nossas ações.

Wegner tenta localizar a origem da EPC no cérebro ou no sistema nervoso para mostrar que a mesma está localizado num local diferente daquele da produção de ação, e que ela ocorre num momento diferente do momento da produção da ação. Isso ajudaria o seu argumento de que a EPC seria separada da produção da ação. Com esse fim, Wegner revisa a literatura que tem se preocupado com os mecanismos desse tipo de experiência

\footnotetext{
${ }^{50}$ De acordo com a interpretação de Eddy Nahmias (2002, p. 530) da teoria de Wegner, a vontade consciente é entendida como um sistema cerebral que interpreta o comportamento em termos de estados mentais: crenças, desejos e intenções. Mas sendo esse um módulo diferente daquele que causaria ações.
} 
(neurocientistas podem variar o nome pelo qual eles chamam EPC), assim como o famoso experimento Benjamin Libet $(1983,1985)^{51}$ que investigou quando a consciência de produzir a ação emerge.

Wegner discute alguns casos de amputação e casos patológicos para descobrir o local onde o ERC é originado, como o fenômeno do membro fantasma e outros casos extraordinários. A investigação, no entanto, é inconclusiva:

Não parece haver uma "fiação da vontade" sendo derramada das conexões entre o cérebro e o corpo, e um começa a se perguntar se os músculos são sequer uma parte necessária do sistema. Em certo sentido, não está claro que quaisquer estudos sobre a sensação de esforço do movimento pode isolar a origem anatômica da experiência da vontade consciente (2002, p. 44).

Essa conclusão poderia fundamentar a ideia de que a EPC parece estar associada aportanto, deve estar conectada a - todos os vários mecanismos considerados relevantes para a produção de ação: a atividade cerebral relevante, as conexões nervosas associadas ao movimento muscular, e as ligações nervosas associadas ao feedback dos músculos relevantes para o movimento. Assim, EPC provavelmente não é algo separado da produção de ações. Poder-se-ia concluir que é exatamente o oposto.

Wegner, contudo, ainda está convencido de que EPC seria produzida separadamente da ação. Ele propõe a hipótese de que a experiência poderia ser produzida por uma combinação de sistemas e processos, e não apenas por um único sistema. Essa sua posição pode se dever à comparação de sua interpretação dos experimentos de Wilder Penfield (1971) e José Delgado (1969), em que os neurocientistas estimulariam áreas do cérebro de pacientes prestes a passar por uma cirurgia no cérebro.

De acordo com Wegner, tanto na experiência de Delgado quanto na de Penfield o paciente movia um membro ou sua cabeça, mas no caso de Penfield eles o acusavam de produzir o movimento, enquanto que no caso de Delgado o paciente tentava explicar o movimento, como se esse tivesse sido espontâneo. ${ }^{52}$ Disso Wegner conclui que a EPC pode

\footnotetext{
${ }^{51}$ Benjamin Libet (1983) conduziu um experimento que comparou o momento em que surge RP antes de um movimento do dedo, ou do pulso, ao momento em que os sujeitos relataram ter consciência da vontade de move. Finalmente, esses foram relacionados ao momento do movimento de fato, que supostamente era um movimento espontâneo feito sem qualquer restrição de tempo. Libet descobriu que o RP surge em torno de $550 \mathrm{~ms}$ antes do movimento, enquanto que a consciência da vontade de movimentar é relatado aproximadamente $200 \mathrm{~ms}$ antes do início do movimento. Assim, o cientista conclui que o cérebro começa a preparar para mover antes do agente ter consciência de sua vontade de mover.

52 Essa diferença entre os experimentos pode ser explicada pela ativação de diferentes áreas do cérebro ou diferente intensidade de ativação. Delgado pode ter ativado uma área que, normalmente, seria relevante para a atenção para a produção da ação — que ajudaria em sua produção—ou relevantes para a coordenação de
} 
ser separada da ação, sendo apenas uma adição que acompanha alguns movimentos. No entanto, o próprio Wegner percebe que essa afirmação se baseia em fundamentos pouco firmes:

No entanto, a investigação que apoia essa ideia tem a forma de algumas observações clínicas iniciais de diferentes pesquisadores, não de uma comparação controlada de algum tipo, e assim nos deixa sem nenhuma indicação satisfatória que a experiência de vontade foi localizada no cérebro ou de que ela pode ser encontrada se a busca correta for montada. E, finalmente, é claro, mesmo esses estudos não conseguem encontrar a vontade per se. $(2002$, p. 60$)$

Ainda assim, ele está convencido de que essa é uma evidência de que a EPC é um “anexo à ação variável” (2002, p. 60). Assim, Wegner volta-se para a localização da EPC no tempo, a fim de provar a sua separação dos mecanismos reais que produzem a ação.

A explicação de quando a EPC ocorre em relação à atividade cerebral relevante para a produção da ação é centrada nos experimentos de Benjamin Libet $(1983,1985),{ }^{53}$ o que resulta numa linha do tempo em que a atividade do cérebro relacionada com a preparação da ação, RP, aparece $350 \mathrm{~ms}$ antes da EPC. Para Wegner isso é suficiente para se afirmar que a consciência não desempenha nenhum papel relevante na produção de ações, e que ela aparece posteriormente, tendo em vista que a EPC ocorreria após a produção da ação já ter começado. $^{54}$

Neste caso, a conclusão seria que a EPC não é relevante para a produção causal da ação, e pode até ser apenas um subproduto dos mecanismos reais que causam ação. "Parece que a experiência de vontade ocorre por meio de um sistema que apresenta a ideia de uma ação voluntária para a consciência e também produz a ação" (2002, p. 60-61). Assim, apesar de Wegner afirmar que a EPC poderia ser produzida pelo mesmo sistema que também produz ações, a EPC seria produzida separadamente e após a produção efetiva das ações já ter se iniciado. Portanto, o experimento dá espaço para Wegner concluir que o surgimento tardio da consciência —o que vem sendo chamando aqui de EPC — no experimento mostraria que a EPC não é relevante para a produção de nossas ações, ao contrário do que o senso comum poderia acreditar.

intenções. Essa possibilidade de explicação do papel da consciência na produção de ações será discutida no Capítulo III.

${ }^{53}$ No experimento, Libet chama isso de consciência ou ciência do impulso ou intenção de agir, dentre outras expressões.

${ }^{54}$ Wegner (2002, p. 55) parece usar o termo vontade consciente e desejo consciente de maneira intercambiável quando ele discute o experimento de Libet (1983). 
Assim, mesmo que Wegner não tenha conseguido localizar a origem da EPC no cérebro em relação à localização da atividade cerebral relevante para a produção de ações, ele acredita ter oferecido prova de que a vontade consciente aparece após a produção da ação ter sido iniciada. Assim, a consciência não poderia desempenhar um papel na produção causal das ações, porque se o fizesse ela teria de vir antes, ou pelo menos simultaneamente aos eventos cerebrais relevantes para a produção da ação. Isso deveria ser o suficiente para mostrar que a produção de ações é independente da EPC, e que a EPC é originada separadamente dos mecanismos que verdadeiramente produzem ações. ${ }^{55}$

A TCMA de Wegner baseia-se em sua conclusão de que a produção da experiência de que nós conscientemente produzimos nossas ações, EPC, é separada da produção de nossas ações. Embora possam ser produzidos pelo mesmo mecanismo subjacente, a produção da EPC viria depois, separadamente da produção da ação:

Os processos descritos neste capítulo [TCMA] repousam em uma premissa importante. Eles se apoiam no pressuposto de que a vontade consciente é uma experiência, não uma causa. Isso significa que os pensamentos que associamos às nossas ações não são necessariamente as verdadeiras causas das ações, e sua conexão causal é algo que nós atribuímos a eles. $(2002,95)$

Wegner acredita ter mostrado que a produção da EPC é separada da produção da ação, o qual serve como uma base para a sua TCMA. Esta é também a evidência necessária para confirmar sua hipótese de que a nossa experiência de que nós causamos nossas ações, EPC, não é nada além de uma inferência que fazemos, e essa inferência produz uma ilusão de como nossas ações são produzidos.

Timothy Bayne (2006), no entanto, discorda. Chama de modelo de correspondência a teoria de Wegner de que a experiência da vontade consciente surge da crença de que nosso pensamento consciente causa nossas ações porque o pensamento preenche aos requisitos de precedência, consistência e exclusividade para que percebamos uma relação de causalidade. Mesmo que Bayne admita que essa correspondência pudesse explicar a experiência da

\footnotetext{
${ }^{55}$ No mesmo sentido, Wegner acredita que a lentidão da consciência de nossas ações automáticas em relação à rápida execução dessas ações mostra que a consciência é uma lesma na produção da ação, em geral. Portanto, a consciência não poderia guiar a ação, como o papel de iniciar ações exigiria. No entanto, Wegner também pondera que a maioria das ações automáticas não seria considerada ações causadas pela vontade, ou voluntárias: "Agora, é claro, muitas das respostas aceleradas que consideramos aqui não são geralmente classificadas como causadas pela vontade. O rápido apertar de uma tecla de resposta numa tarefa de tempo de reação não é, certamente, o protótipo da ação voluntária porque não é espontânea e é regida pela ocorrência de um sinal externo" (WEGNER, 2002, p. 58).
} 
agência, ele argumenta que essa não é uma prova de que essa experiência seja, ou de que ela promova uma ilusão.

Ele discorda de que a teoria de Wegner ofereça uma boa razão para se aceitar que a eficácia causal das intenções seja uma ilusão, "a maneira mais fácil de se ler Wegner é considerando que ele esteja oferecendo o modelo de correspondência como evidência para a afirmação de que a vontade consciente é uma ilusão" (BAYNE 2006, p. 169). Outro ponto interessante dessa discussão, entretanto, é a evidência oferecida pelo experimento Libet de (1985 1983); essa evidência será discutida na próxima seção.

\section{RPs não são preparação da ação: a estimativa de tempo da EPC está errada}

Wegner tenta localizar a EPC no espaço e no tempo; i.e., sua origem em uma parte do cérebro ou no sistema nervoso e no cronograma da produção de ação a fim de proporcionar mais apoio para a tese de que a experiência da vontade consciente é algo aparte da produção efetiva de ações e que não desempenha um papel relevante na produção da ação. O objetivo era mostrar que EPC não é causalmente relevante para a produção de nossas ações.

Como foi discutido acima, a localização da EPC no cérebro permanece sendo difícil de determinar. Quanto ao momento de seu surgimento, Wegner afirma que a experiência é originada depois que o cérebro começa a preparar para agir; por conseguinte, A EPC não seria relevante para a produção das ações, uma vez que é iniciado após a produção em si já ter começado.

Nós não sabemos quais processos mentais inconscientes específicos o RP pode representar. É provável que esses processos sejam relevantes de alguma forma para os eventos que se seguem, é claro, porque eles ocorrem com regularidade precisa anteriormente a esses eventos. Agora, os eventos que se seguem incluem a experiência de querer mover $e$ o movimento voluntário. $\mathrm{O}$ $\mathrm{RP}$ poderia, assim, indicar a ocorrência de eventos mentais inconscientes que produzem ambas a experiência de querer mover e a ocorrência de movimento real. Essa possibilidade nos alerta para a percepção intrigante de que vontade consciente, bem como ação voluntária, é um evento mental que é causado por eventos anteriores. (WEGNER, 2002, p. 55) 
No momento em que Wegner escreveu seu livro não estava claro o que RPs representam. Novas evidências, no entanto, sugerem que RPs não representam preparação para mover e, portanto, não mostram de maneira confiável que a preparação inconsciente do cérebro para um movimento específico precede a consciência na produção causal da ação (JO et al., 2013; SCHLEGEL et al., 2013; SCHURGER et al., 2012; TREVENA e MILLER, 2010; HERRMANN et al., 2008).

Isso coloca em questão a tese de que a consciência apareceria tardiamente na linha do tempo da produção de ações. Se o RP não representa preparação para mover, então, não há nenhuma evidência de que a produção da ação se inicia antes de o agente tem qualquer consciência de estar produzindo sua ação. Afinal de contas, a preparação para um movimento específico é colocada antes do que a EPC na linha do tempo do experimento de Libet porque o RP pode ser observado bem antes da ação, e antes dos sujeitos relatarem ter a EPC. Dito isto, vale a pena olhar para essas experiências que questionam a associação de RP com a preparação para um movimento.

Jo et al. (2013) desenvolveram um experimento para investigar se os mesmos componentes do RP são observados antes de ensaios [trials] com movimentos auto-iniciados e com não-movimento. Os sujeitos deveriam executar uma tarefa semelhante à do experimento de Libet, um movimento auto-iniciado, ou eles deveriam não se mover, sendo essa a condição de não-movimento. Os cientistas classificaram o Potencial Cortical Lento (PCL) como mudança negativa contínua e mudança positiva contínua, tanto em condições de movimento auto-iniciado como em condições de não-movimento. ${ }^{56}$

Não foi observada diferença na parte inicial dos potenciais de mudanças para as diferentes tarefas: movimento auto-iniciado e não-movimento. Os experimentadores concluem que uma razão desigual de mudanças negativas e positivas do PCL originaria o RP negativo antes do movimento, mas o RP não representaria preparação para mover, uma vez que as mudanças negativas contínuas de SCP apenas facilitariam os movimentos autoiniciados reduzindo o limiar de excitação, tornando assim mais provável que o movimento ocorra, de acordo com Jo et al. Os experimentadores sugerem que RPs refletem processos gerais de preparação (não para mover especificamente).

"[...] Se o RP médio reflete a flutuação espontânea da atividade neuronal, em vez de preparação para um movimento, então, os mesmos componentes do RP seriam observados não só na condição de movimento auto-iniciado, mas também na condição de não-

\footnotetext{
${ }^{56}$ A condição de movimento auto-iniciado era uma tarefa do estilo do experimento de Libet. E a condição de não-movimento era um estímulo auditivo aleatória.
} 
movimento" ( JO et al., 2013, p. 496). Os experimentadores descobriram que até $500 \mathrm{~ms}$ antes do movimento não houve diferença significativa na atividade neuronal de condições de movimento auto-iniciado e de não-movimento.

A mudança negativa contínua de PCL está associada à facilitação para iniciar um movimento, em comparação com as mudanças positivas, por abaixar o limiar para o movimento. Portanto, a deflexão negativa do PCL facilitaria o movimento, mas não corresponderia a uma decisão de mover. Assim, um sujeito que concentrasse sua atenção para eventos internos - como a vontade de agir no experimento de Libet- estará mais propenso a agir durante desvios negativos do SCP. Os experimentadores concluíram que a parte inicial do RP não representa preparação motora pré-consciente para agir; ela apenas reflete processos de preparação geral.

Schlegel et al. (2013) constataram que RP não mostra uma covariação em relação à W (momento da consciência da vontade de mover no experimento de Libet). Eles também não encontraram nenhuma relação entre o Readiness Potencial Lateralizado (RPL) e, o que eles chamam de a sensação da vontade, representada por W. Essa conclusão foi baseada no fato de que o momento do suposto efeito, $\mathrm{W}$, não se correlacionou com o momento da suposta causa: RP. Schlegel et al. enfatizam que normalmente supomos que o momento de uma causa deva variar de acordo com o momento do seu efeito, para que haja uma relação causal, mas essa correlação de tempo não foi encontrado entre RP e W ou entre RPL e W. Na verdade, Schlegel et al. não relacionam RP à preparação do movimento ou ao que eles chamam de vontade; eles apenas o relacionam à antecipação geral, ou mesmo apenas a atividade em curso. "No geral, a experiência sugere que o RP e o RPL não se correlacionam com-e, portanto, não refletem a causa - a experiência consciente da vontade” (2013, p. 04).

Schurger, Sitt, e Dehaene (2012) reproduziram o experimento clássico de Libet, e também desenvolveram o que eles chamaram de Libetus interruptus, desenvolvido para investigar o que representam RPs realmente. O último foi o mesmo que o experimento clássico de Libet com a adição de que os indivíduos podiam ser interrompidos por um som (num momento aleatório) durante o ensaio, e nesse caso eles deveriam pressionar o botão o mais rápido possível.

A nossa previsão primário foi que as respostas rápidas para interrupções (um clique auditivo) tenderiam a ser precedidas por um desvio de voltagem contínua-negativa gradual: se o córtex motor já estiver um tanto mais próximo do limiar para o movimento no momento em que ocorre a interrupção, então o movimento será iniciado mais rapidamente em resposta. Em contrapartida, a visão amplamente aceita do RP como sendo uma 
sequência de cálculos específicos que antecedam um movimento autoiniciado não prevê um acúmulo semelhante antes uma resposta a um sinal inesperado. (SCHURGER, SITT, e DEHAENE, 2012, p. E2909)

Os experimentadores registraram o RP dos sujeitos em ambos os experimentos, e eles descobriram que ambos apresentaram flutuação de RP. Assim, mesmo durante Libetus interruptus, em que ocorre o som (clique), supostamente em momentos em que o sujeito não está se preparando para mover, foi gravada flutuação do RP antes do som. E foi observado acúmulo de potencial antes de respostas rápidas às interrupções.

Isso sugere que há flutuação do RP a maior parte do tempo, mesmo quando os indivíduos não estão se preparando para mover. Apenas quando esse potencial atravessa um limiar isso aumentaria a probabilidade de movimento. Quando o limiar foi atravessado no experimento, ele foi atravessado cerca de $150 \mathrm{~ms}$ antes do início do movimento, o que está de acordo com as descobertas de Libet. No entanto, os cientistas discordam de Libet a respeito de suas conclusões, porque eles acreditam que ambos os experimentos mostram que os sujeitos relatam estar conscientes da vontade de movimentar cerca de $200 \mathrm{~ms}$ antes do início do movimento, exatamente porque esse é o momento em que o limiar de decisão ${ }^{57}$ é atravessado (2012, p. E2910). ${ }^{58}$

Trevena e Miller (2010) reproduziram o experimento de Libet com a diferença de que quando os participantes ouviam um tom aleatório eles deveriam imediatamente decidir mover ou não mover. A experiência foi concebida para observar a medição de negatividade no EEG antes de decisões para mover e decisões para não mover, a fim de marcar a diferença entre a negatividade em ambos os casos, e investigar se a negatividade anterior ao movimento pode ser um indicador confiável da preparação para mover. "[...] Os participantes deveriam estar mais propensos a mover se o som soa enquanto essa negatividade é grande, e mais propensos a decidir não mover se o som soa enquanto essa negatividade é pequena” (2010, p. 448).

Os experimentadores constataram que não houve diferença significativa na negatividade antes de ensaios em que os sujeitos decidiram mover daquelas em que eles decidiram não mover. Havia níveis semelhantes de negatividade antes do tom e após o tom

\footnotetext{
${ }^{57} \mathrm{O}$ limiar de decisão é o nome que os experimentadores deram para quando o potencial em questão atravessava o limiar que tornava mais provável haver movimento.

${ }^{58}$ Essa hipótese também fornece an resposta para a questão levantada pelo experimento de Libet: por que os sujeitos eram capazes de estimar o tempo de uma decisão sensorial tátil com um atraso de apenas $50 \mathrm{~ms}$, enquanto eles precisariam de mais de $300 \mathrm{~ms}$ para estimar o tempo da sua decisão motora? De acordo com os cientistas esse problema surge a partir da crença de que a decisão motora ocorreria no momento do surgimento do RP. Eles argumentam, no entanto, que a decisão motora ocorreria em torno de $150 \mathrm{~ms}$ antes do início do movimento e que ela coincide com o tempo médio da consciência do desejo de mover dos sujeitos (2012, p. E2910).
} 
em ensaios em que os sujeitos moveram e em ensaios em que não moveram. Disso, os experimentadores concluíram que a negatividade que precede movimentos estaria relacionada com o envolvimento do agente com a tarefa, talvez com sua atenção, mas não com a preparação para empreender um movimento específico; portanto, o RP não representaria negatividade relacionada ao movimento.

Herrmann et al. (2008) também afirmam que, em um experimento em que os indivíduos foram instruídos a pressionar um entre dois botões, dependendo de qual estímulo fosse apresentado, a atividade neural presente antes de respostas motoras surge bem antes do estímulo ser apresentado, por isso, antes dos sujeitos poderem decidir qual botão pressionar. Observou-se que antes de saber qual botão os sujeitos seriam instruídos a pressionar "a ativação anterior ao estímulo não diferiu significativamente entre as duas alternativas de resposta. Assim, a atividade observada não pode ser considerada como uma preparação específica para pressionar um dos botões, em vez do outro" (2008, p. 156). Eles concluem que a atividade reflete a expectativa geral de uma tarefa.

Levando essas descobertas recentes em consideração, colocar a EPC na linha do tempo da produção ação como ocorrendo após a produção da ação já ter começado, como sugere a interpretação que Libet faz de seus resultados, é injustificado. Os experimentos discutidos acima questionam o que a presença do RP antes da ação poderia representar; por exemplo, estar presente antes do movimento e antes de tarefas que não envolvem movimento. Nas conclusões experimentais, os neurocientistas parecem concordar que o RP não representa preparação para mover; provavelmente representa preparação geral ou antecipação de uma tarefa. Portanto, não há nenhuma evidência convincente de que a EPC surgiria tardiamente na produção de ações, ou que não contribuiria causalmente para a mesma. Tendo em vista que o surgimento do RP tem sido considerado o início da produção da ação, as recentes descobertas discutidas acima sugerem que essa interpretação da linha do tempo da produção da ação está equivocada.

Portanto, não podemos concluir a partir das descobertas de Libet que EPC é produzida separadamente da produção de ação, ao contrário do que Wegner argumenta. Nem podemos afirmar que a consciência é de fato irrelevante nesta produção, uma vez que não podemos com base no surgimento do RP dizer que ela aparece após a produção da ação ter sido iniciada. Na verdade, Schurger, Sitt, e Dehaene (2012) sugerem que a experiência da vontade (o que eu tenho chamado de EPC) acontece aproximadamente ao mesmo tempo que o início da produção de ação, quando o potencial relacionado com a produção de ação atravessa o 
limiar de decisão. A experiência de conscientemente produzir ações pode ser a experiência que a consciência é de fato relevante para a produção de ações.

Como a TCMA de Wegner depende da hipótese de que a EPC é produzida por um sistema separado daquele da produção de ações, então, se considerarmos que Wegner não demonstrou que há de fato tal separação, então sua teoria está fundamentada em alicerces pouco seguros. Eu acredito que os estudos recentes que investigam o que RP representa mostram que Wegner não forneceu provas suficientes para concluir que haja essa separação entre as produções de EPC e da ação.

\section{Considerações finais}

Wegner argumenta que a nossa experiência de que a consciência desempenha um papel na produção de nossas ações está equivocada, e contribui para uma ilusão. Wegner acredita nisso porque, com base no experimento de Libet $(1983,1985)$, ele conclui que essa experiência aparece tardiamente na linha do tempo da produção de ações. Uma vez que essa conclusão está fundamentada em uma crença sobre o papel que o RP tem na produção da ação, foram discutidos experimentos que colocam em questão o suposto papel do RP.

Se o RP não puder ser tratado como o início da produção da ação, então não há razão para afirmar que EPC surge após a produção da ação ter começado apenas porque EPC surge após o RP. E isso enfraquece a razão que Wegner oferece para se crer que EPC não desempenharia um papel na produção de ações. Finalmente, ele não mostrou que a EPC é produzida separadamente da ação. Nesse sentido, será oferecida no próximo Capítulo (Capítulo III) uma explicação alternativa para o papel que a EPC poderia desempenhar na produção de ações, que pode ajudar a entender por que temos essa experiência em algumas produções de ações, mas não em outras. 


\section{Capítulo III - A Consciência das Intenções e o Conceito de} Agentes

\section{Introdução}

Teorias bem conhecidas da Causalidade do Agente (CA) dependem de uma concepção de agência que as leva a esperar que os agentes desempenhem certo papel na produção de sua ação, um papel consciente. Esse é o fundamento para que essas teorias coloquem a objeção do Desaparecimento do Agente (DA) contra a Teoria Causal da Ação (TCA). Daniel Wegner (2002) recentemente defendeu de forma semelhante a alegação de que a consciência é um critério de definição para a agência (embora sua teoria sobre a produção das ações seja muito diferente daquela defendida pela CA). Wegner não é adepto da teoria da CA, contudo, ele propõe uma versão mais moderna da perspectiva que considera a consciência parte relevante da agência; tanto que se a consciência não desempenhasse um papel na produção das ações, não haveria um papel para o agente nela.

No entanto, no presente estudo será argumentado que a consciência desempenha um papel diferente daquele esperado pelas teorias tanto da CA, quando de Wegner, o que nos dá razão para pensar que essa concepção de agência deve ser revista. Igualmente, o DA deve ser revisto, dado que o problema surge dessa concepção de agente que está sendo questionada. Contudo, essa revisão do conceito de agente será reservada para os capítulos 4 e 5.

Aceitamos a teoria de que podemos estar conscientes de algumas das nossas intenções e não consciente de outras (MELE, 2009). Então, é importante explicar como isso é possível: ter consciência de algumas das nossas intenções e não ter consciência de outras, e qual papel a consciência desse estado mental desempenharia na produção das ações. ${ }^{59}$ Afinal, seria estranho do ponto de vista evolutivo afirmar que a consciência não desempenha papel algum, ou que a nossa experiência consciente das nossas intenções e de que causamos nossas ações

\footnotetext{
${ }^{59}$ Quando dizemos que um estado mental é consciente, não estamos dizendo que o estado mental em questão tem consciência, assim como uma pessoa tem consciência. Estamos dizendo que a pessoa tem consciência desse seu estado mental (MELE, 2009, p. 22-23). É nesse sentido que entendo que Wegner se refere à vontade consciente.
} 
não têm nenhuma função na produção das nossas ações. ${ }^{60}$ Uma hipótese será proposta para explicar essa oscilação, sugerindo que estaríamos conscientes das intenções cujos realizadores atingiram certo limiar de ativação, principalmente em situações que requerem aprendizagem, ações complexas, situações novas, e decisões, dentre outras.

Nesse capítulo será argumentado que a tese de Wegner de que estados mentais conscientes não podem desempenhar um papel causal na produção de ações e que, na verdade, estados inconscientes desempenham esse papel, o leva a afirmar que não somos agentes (2002, p. 341-42). Porém, parece que agimos. Assim, a Hipótese de Difusão, que será proposta nesse capítulo, sugere qual papel a consciência das intenções poderia desempenhar na produção das ações.

Será argumentado que a objeção dos teóricos da causalidade do agente a respeito do DA na produção das ações (SCHROETER, 2004; HORNSBY, 2008; STEWARD, 2012), assim como a conclusão de Wegner de que não somos agentes, iguala a falta de consciência com a falta de um papel desempenhado pelo agente nessa produção. A relação da consciência com o papel do agente fundamenta uma concepção específica do que são agentes e de qual deve ser seu papel na produção de ações. Nesse sentido CA se assemelha à teoria de Wegner. Se a hipótese proposta nesse capítulo for aceita, no entanto, essa concepção de agência deve ser revista, o que leva a um novo enfoque do problema do DA.

Nesta seção e nas seções 3 e 4 será discutida a relação entre a objeção de Wegner à noção de que estados mentais conscientes (principalmente intenções) desempenham um papel causal na produção das ações e a conclusão de que não causam o que fazemos, i.e., que não somos agentes. Isso tornará aparente a associação feita pelo autor entre consciência e agência, o que explica porque Wegner finalmente conclui que não somos agentes. Nas seções 5 e 6 a Hipótese da Difusão será proposta para responder à objeção de Wegner a respeito do papel causal da consciência de estados mentais na produção de ações.

\section{A falta de um papel para a consciência das intenções na teoria de Wegner}

\footnotetext{
${ }^{60}$ Mesmo que consideremos que Wegner está tratando da consciência de segunda ordem-i.e., da vontade consciente - e que apenas a consciência de primeira ordem teria surgido por pressões evolutivas, podemos supor que a consciência de segunda ordem teria surgido a partir da primeira para cumprir outras funções (como uma instância de exaptação). Assim, Wegner ainda precisaria explicar por que teríamos vontade consciente (consciência da chamada vontade) se essa não tivesse qualquer função.
} 
O argumento de Wegner é que algumas ações são automáticas; portanto, não teríamos consciência de sua produção (2002, p. 97). Em alguns casos extremos, o agente pode até mesmo não estar consciente de que ele está agindo: "automatismos envolvem essa falta da sensação de fazer uma ação, mas podem até ir além disso incluindo uma nítida sensação de que não estamos agindo" (WEGNER, 2002, p. 99), como nos casos de hipnose e escrita automática. Wegner conclui, então, que a consciência não é parte de toda produção de ações (2002, 97). Portanto, a explicação da produção das ações não poderia envolver estados mentais conscientes, porque faz mais sentido que todas as ações (conscientes e inconscientes) tenham uma causa comum.

Ademais Wegner leva em consideração os resultados encontrados por Benjamin Libet (1985) em seu famoso experimento. Em resumo, Libet (1985) afirma que havia preparação da atividade cerebral para agir, i.e, o potencial de prontidão (RPs) surge 300 milisegundos antes de os sujeitos do seu experimento terem consciência de sua intenção de agir. Assim, Libet conclui que ações não são originadas conscientemente pelo agente. ${ }^{61}$ Por isso, Wegner acredita que ações são causadas por atividades inconscientes, que seriam comuns tanto à produção das ações de cuja produção temos consciência quanto das de cuja produção não temos essa consciência.

Wegner defende a tese de que os estados mentais que normalmente associamos à produção de ações seriam conscientes - e.g., que intenções seriam pensamentos conscientes que precederiam a ação $(2002,18)^{62}$ - o que leva o autor a concluir que esses estados mentais não poderiam desempenhar um papel causal na produção de ações. Afinal, Wegner defende que mecanismos inconscientes são a causa das ações: "devemos lembrar que essa análise sugere que os verdadeiros mecanismos causais subjacentes ao comportamento nunca estão presentes na consciência [...] as verdadeiras causas das ações humanas são inconscientes" (WEGNER, 2002, p. 97). Como prova disso, Wegner lembra que algumas ações são produzidas inconscientemente.

A Teoria da Causalidade Mental Aparente (TCMA) desenvolvida por Wegner afirma que a verdadeira causa da ação é inconsciente. Nesse sentido, a experiência consciente que temos de que alguns de nossos estados mentais causam nossas ações é apenas uma ilusão.

\footnotetext{
${ }^{61}$ Apesar de Libet reservar espaço para o Livre Arbítrio ao defender que o agente tem o poder de vetar a produção da ação enquanto e mesma ainda está em curso.

${ }^{62}$ Consideraremos que Wegner está se referindo a intenções imediatas. O autor não leva em consideração intenções distais em sua teoria.
} 
Os automatismos têm um lugar especial na análise da aparente causalidade mental, é claro, porque eles representam uma classe de casos em que a aparente causalidade mental falha. Isto significa que se a vontade consciente é ilusória, automatismos são de alguma forma a "coisa real", mecanismos mentais fundamentais que sobram uma vez que a ilusão tenha sido retirada. (WEGNER, 2002, p. 143)

De acordo com essa compreensão, a nossa experiência de que causamos nossas ações conscientemente seria uma ilusão, porque apenas mecanismos inconscientes teriam um papel causal na produção de ações. Com base nessa noção, Wegner ainda conclui que temos a ilusão de sermos agentes: "O fato é que parece para cada um de nós que temos vontade consciente. Parece que somos selves. Parece que temos mentes. Parece que somos agentes. Parece que causamos o que fazemos" (WEGER, 2002, p. 341-42). Mas essas impressões não passariam de ilusões.

Essa conclusão se assemelha ao que teoria da CA caracteriza como o problema do DA (VELLEMAN, 1992; HORNSBY, 2008; STEWARD, 2012). A TCMA afirma que não há um agente desempenhando um papel na produção de ação, porque, segundo Wegner, não causamos o que fazemos (WEGNER, 2002, p. 341-42), e essa falta de papel para o agente é a preocupação no DA. Embora a forma tradicional de pensar o problema se refira à atribuição da causa da ação a eventos mentais e suas causas anteriores, o que supostamente eliminaria o papel do agente na produção das ações (NAGEL, 1987; VELLEMAN, 1992), a teoria de Wegner levanta o mesmo problema, colocado de maneira diferente e mais explícita. No entanto, o autor não considera que o DA seja problemático e aceita a sua conclusão de que não somos agentes, enquanto que os teóricos da CA considerariam isso inaceitável.

Wegner excluiu qualquer estado consciente da produção de ação. Portanto, ele conclui que não somos agentes, de acordo com a sua concepção de agência, porque sua concepção de agência parece requerer consciência, assim como a da CA. No entanto, essa conclusão é estranha e é motivada pela suposição de que o agente está associado com a parte consciente de seus estados mentais. Nesse contexto, devemos nos perguntar se agência efetivamente requer consciência.

Assim, para que Wegner aceite que o agente de uma ação produziu sua ação, sua consciência teria que desempenhar um papel na produção da ação. Mas de acordo com a teoria de Wegner isso não é possível, nós só temos a ilusão de que a consciência tem um papel nessa produção; portanto, não podemos ser agentes.

Wegner parece acreditar que se estados mentais conscientes participassem da produção da ação, esses constituiriam a marca do agente e seriam a única maneira pela qual o 
agente teria um papel nessa produção. Assim, se esses estados conscientes não fizerem parte da produção da ação, então o agente não participaria de sua ação. A semelhança entre a assertiva de Wegner a respeito de não sermos agentes e o DA serão discutidos na seção 3. Isto torna claro que o papel dos estados mentais conscientes na produção das ações, e se esses são conscientes ou não, são questões importantes para como agentes são concebidos.

\section{Concebendo intenções como sendo estados mentais conscientes}

Olhando mais de perto as razões de Wegner para rejeitar que estados mentais conscientes sejam parte da produção causal da ação, é possível perceber que o autor considera problemático que em algumas ações o agente tenha consciência da produção da ação, enquanto que em outras ações não. Wegner cita uma série de automatismos para exemplificar situações nas quais não estamos conscientes da produção de nossas ações, como escrita automática, hipnose, etc. Estendendo essa conclusão, por indução, para todos os outros estados mentais, o autor conclui que os estados mentais associados à consciência, como intenções conscientes, não fariam parte da produção causal da ação.

Faz sentido pensar que intenções sejam ou conscientes ou não-conscientes. ${ }^{63}$ Wegner, porém, considera que intenções seriam estados mentais conscientes; afinal, em muitas situações, as pessoas tendem a relatar terem consciência da intenção que as levou a agir. No entanto, essa concepção de intenções não é um consenso; há teorias que aceitam que intenções podem também ser não-conscientes (MELE, 2003, 2009; BRATMAN, 1999) e a admissão de que existem intenções não-conscientes mina a concepção de Wegner.

Tentamos entender como seria possível que na produção de ações as intenções às vezes pudessem ser conscientes e outras vezes não. Aqui será aceita a tese da TCA de que as intenções são causalmente relevantes para a produção de ações; além disso, é possível que intenções das quais o agente esteja consciente expliquem casos em que o mesmo está consciente da produção da sua ação melhor do que a teoria de que esses casos envolvem uma ilusão dessa produção. No entanto, se for aceito que intenções são importantes para explicar

\footnotetext{
${ }^{63}$ Ao me afastar da teoria de Wegner, eu prefiro o termo não-consciente, como foi explicado no capítulo anterior. No presente capítulo defenderei que alguns estados mentais podem as vezes era conscientes e outras vezes não conscientes na produção de ações. No segundo caso, o agente não estaria consciente do estado mental em questão no momento.
} 
ações, como a TCA propõe, é preciso explicar como os agentes podem estar conscientes do papel causal das intenções na produção de algumas ações, mas não em outras.

Ademais, será argumentado que a consciência de uma intenção tem um papel na produção de ações, que não é o de gerar uma noção equivocada de como produzimos nossas ações. A consciência dos estados mentais que participam dessa produção tem um papel também diferente daquele atribuído pela CA à participação consciente na produção da ação, como será explicado.

\section{O problema: como intenções podem ser tanto conscientes quanto não- conscientes?}

Voltamo-nos para o problema que a consciência das intenções traz para a explicação de ações defendida pela TCA. Enquanto algumas ações podem ser automáticas e não parecem envolver a consciência em sua produção, outras podem ser conscientemente produzidas. Por exemplo, um adolescente pode estar bem ciente de todos os seus gestos e motivações ao falar com o objeto de sua afeição. Ao mesmo tempo, um lutador de kung-fu pode fazer um movimento de defesa tão rápido quando seu oponente tenta golpeá-lo que ele sequer está ciente da produção de sua ação. Igualmente, os passos de uma bailarina podem estar tão bem ensaiados que, ao dançar no palco, ela pode não estar consciente de qual passo exatamente ela está executando, de modo que ela pode concentrar-se apenas no tempo da música.

Essa distinção entre a produção consciente e não-consciente de ações representa um problema para TCA, pois é necessário explicar como a teoria pode alegar que as intenções podem oscilar sendo conscientes, em algumas ações, e não-conscientes em outras. E, desse modo, explicar como podem ter participação causal na produção de ações conscientes e nãoconscientes, enquanto que essa produção ocorreria da mesma forma em ambos os casos. Deve haver uma diferença funcional entre a intenção consciente e não-consciente, caso contrário, a consciência nesses estados mentais não teria nenhuma função na produção de ações, e seria difícil explicar por que teríamos essa consciência. Quando a intenção é consciente, isso certamente deve incluir uma diferença na produção da ação. 


\section{Piscada atencional}

Um experimento envolvendo piscada atencional ${ }^{64}$ da percepção será descrito nessa seção. A analogia com a percepção será importante para desenvolver um paralelo entre percepções conscientes e não-conscientes e intenções conscientes e não-conscientes, a fim de desenvolver uma possível explicação para a diferença entre as últimas. À luz da explicação dessa diferença entre intenções conscientes e não-conscientes se torna possível desenvolver uma hipótese para explicar a função desempenhada pela consciência das intenções.

Sergent et al. (2005) desenvolveram um experimento envolvendo piscada atencional com o qual é possível traçar um paralelo com as intenções. Os experimentadores sugerem que seus resultados ajudam a explicar por que às vezes os sujeitos do experimento relatam ver os dois estímulos apresentados, enquanto que outras vezes eles relatam terem visto apenas o primeiro dos dois. ${ }^{65} \mathrm{O}$ último caso é chamado de piscada atencional. Os sujeitos do experimento podem falhar em atentar para o segundo estímulo quando este é apresentado logo após o primeiro.

Em uma tela, um estímulo, T1, era apresentado aos participantes do experimento, rapidamente seguido por uma máscara. ${ }^{66}$ Em seguida, após um curto intervalo de tempo, outro estímulo T2, seguido de duas máscaras, aparecia na tela. Nas sessões controle, em vez de T2, uma tela em branco era mostrada, seguida por duas máscaras. Os participantes deveriam executar uma das duas tarefas: (1) relatar o grau de visibilidade de T2 em uma escala, ou (2) relatar o grau de visibilidade de T2 e executar uma tarefa de discriminação sobre T1. Durante todo o processo, potenciais relacionados a eventos (ERPs) dos participantes foram medidos. Os resultados mostraram que quando os sujeitos tinham duas tarefas a executar (caso 2) eles viam T2 em algumas sessões, mas não em outras. Isso coincidiu com um padrão diferente de ERPs evocado $270 \mathrm{~ms}$ após T2 para cada situação: visto e não-visto. ${ }^{67}$

\footnotetext{
${ }^{64}$ Tradução do fenômeno conhecido como attentional blink.

65 Atenção e consciência são muitas vezes correlacionados na neurociência (TREISMAN, 2004). Alguns neurocientistas consideram a atenção um requisito necessário para a consciência (COHEN, 2012). No experimento de Sergent et al. sobre piscada atencional fica claro que "a consciência no nível de relato" (MELE, 2009) é a questão central.

${ }^{66}$ Um breve estímulo distrator apresentado de forma que o participante não atente para o mesmo. O papel desse estímulo é reduzir a visibilidade dos alvos visuais do experimento: T1 e T2. No experimento em questão as máscaras eram as letras maiúsculas XOOX ou OXXO apresentadas 43 milissegundos após cada estímulo.

${ }^{67}$ Não houve diferença significativa nos primeiros $180 \mathrm{~ms}$. Ambas as ondas P1 e N1 foram semelhantes em ambas as situações. Nas sessões em que os sujeitos relataram ter visto T2, seus ERPs N2 foram mais intensos, e as ondas $\mathrm{N} 3, \mathrm{~N} 4$, e P3b só estiveram presentes em sessões em que mais de $50 \%$ de visibilidade de T2 foi relatada.
} 
Além disso, Sergent et al. encontraram um resultado interessante: a tarefa T1 evocou as ondas $\mathrm{N} 2, \mathrm{P} 3 \mathrm{a}$, e P3b, ${ }^{68}$ que também estão presentes no processamento de T2. Isso pode explicar porque em algumas sessões T2 era visível, mas não em outras, uma vez que os processamentos de T1 e de T2 competem pelos mesmos recursos. Os experimentadores concluíram que se o processamento de T1 coincide com o processamento de T2 em uma fase posterior, cerca de $270 \mathrm{~ms}$, T2 só será visível nas sessões em que o processamento de T1 associado ao acesso consciente - ondas N2, P3a e P3b-ocorrer rapidamente. Ou em casos em que o processamento seja antecipado, de modo que o último estágio, P3b, não compita com a onda N2 evocada pelo processamento de T2. Isto sugere que o processamento da percepção toma recursos de capacidade limitada. Assim, T2 não é visto em sessões em que a onda P3b associada com o processamento de T1 compete com a onda N2 evocada por T2.

Nas sessões em que os sujeitos relataram que viram T2, Sergent et al. descobriram que a antecipação da onda Pb3 relacionada a T1 evitava a competição com a onda N2 evocada por T2. Também, N3 teria reduzido de intensidade em sessões em que houve piscada atencional. Estes resultados sugerem que o processamento não-consciente de T2 continua nas sessões em que não houve visibilidade de $\mathrm{T} 2$, e o seu processamento pode ocorrer ao mesmo tempo em que está acontecendo o processamento consciente de $\mathrm{T} 1 .^{69}$

Embora a segunda fase do processamento não possa ser localizada de forma inequívoca com os dados obtidos dos ERPs, Sergent et al. acreditam que há indícios de que em sessões em que T2 é visto há ativação de regiões cerebrais distribuídas, especialmente a parietal associativa e áreas frontais. Isto é consistente com a Teoria do Espaço de Trabalho Global (Global Workspace Theory - TEG), que propõe que depois de atingir um limiar de ativação, a percepção ganharia acesso à consciência, sendo distribuída para diferentes áreas do cérebro - pré-frontal, parietal e cingulado anterior. Essas áreas são consideradas o espaço global de trabalho, que amplifica o sinal para a região visual (dado que nesse caso o estímulo é visual). Assim, atingir o limiar de ativação provocaria a mobilização do espaço global de trabalho, e a globalização da atividade é o que constituiria o acesso à consciência de acordo com esta teoria.

A TEG proposta por Baars (1988) reúne características de diferentes arquiteturas cognitivas que visam explicar a consciência, como ativação, distribuição e capacidade

\footnotetext{
${ }^{68} \mathrm{~N} 1, \mathrm{~N} 2, \mathrm{~N} 3, \mathrm{P} 1, \mathrm{P} 2, \mathrm{P} 3 \mathrm{a}$ e P3b são todos ERPs evocados pela percepção visual no cérebro. Os números relativos a cada potencial referem-se à ordem cronológica em que são normalmente observados. A observação do surgimento desses ERPs e como eles são afetados pela percepção dos estímulos apresentados pelos pesquisadores são fundamentais para a interpretação do experimento.

${ }^{69}$ Dehaene et al. (2006) corroboram essa conclusão.
} 
limitada. De acordo com essa teoria, a consciência envolve certa quantidade de ativação dos processadores; esses deve atingir um limiar para que uma percepção ou memória se torne consciente. Além disso, o sistema é distribuído em componentes fortemente descentralizados, tendo cada um seus próprios limiares para a distribuição no espaço global. O espaço global de trabalho seria uma memória de trabalho cuja capacidade é limitada, e por meio desse espaço de trabalho componentes especializados poderiam transmitir conteúdo para todo o sistema, o que significa que poderia haver competição entre os sistemas pela transmissão de seus conteúdos.

De acordo com a teoria de Baars, em um sistema de processamento de informação distribuído não há uma central executiva. A função executiva varia de forma flexível entre os subsistemas, dependendo da tarefa a ser executada. A sua descentralização mostra a necessidade de um espaço de trabalho central por meio do qual os sistemas menores possam trocar informações. Assim, pode haver competição para transmitir a informação dos sistemas de processamento, já que a informação transmitida torna-se dominante em todo o sistema. Neste sentido, alcançar consciência seria um tipo de seleção de informação; no caso do experimento, informação de percepção.

Baars chama de contexto a estrutura não-consciente das experiências conscientes. Embora esses processos nunca sejam eles próprios conscientes, eles moldam a experiência consciente subjacente às nossas expectativas do que seria a nossa percepção do mundo. De acordo com Teoria do Espaço de Trabalho Global, os seres humanos têm contextos imagemperceptuais, contextos conceituais e contextos de objetivo, que fundamentam suas correspondentes experiências conscientes de percepções, imagens, conceitos e objetivos. Contextos de objetivo são organizados em uma hierarquia por significado. Nesse sentido, os objetivos mais importantes prevalecem sobre as menos importantes, pelo menos pelo período em que for considerado mais importante.

\section{Um paralelo com as intenções}

Intenções são também, às vezes conscientes e outras vezes não, como ocorre com as percepções na piscada atencional. Desenvolver uma explicação de como a consciência de intenções pode variar ajudaria a esclarecer qual papel a consciência desse estado mental 
poderia ter na produção causal das ações. A hipótese que será proposta, chamada de Hipótese de Difusão, não associa a consciência ao papel do agente na produção de ação. Neste contexto, a falta de consciência de uma intenção na produção de ação não implica que o agente não teria um papel relevante nessa produção. Esse é o caso porque, de acordo com essa hipótese, a consciência não está associada à agência na produção da ação, ${ }^{70}$ nem ao controle sobre as ações. Nossa hipótese defende que a consciência de intenções imediatas tem apenas o papel de difundir ${ }^{71}$ informações pelo sistema.

Para responder à objeção de Wegner à participação de estados mentais conscientes na produção de ações é necessária uma explicação de como as intenções poderiam ser conscientes em alguns casos e não-conscientes em outros e de como essa distinção afetaria a produção da ação. A TCA não faz nenhuma diferença entre a eficácia causal das intenções conscientes e das não-conscientes. Segundo essa teoria, as intenções participariam da produção causal das ações aproximadamente da mesma forma, independentemente de serem elas conscientes ou não. Por isso, a intenção não-consciente do lutador de kung-fu de se defender do ataque de seu oponente deve desempenhar o mesmo papel causal que desempenharia se a mesma fosse consciente.

Esse papel causal, por exemplo, de iniciar e guiar a ação, seria o mesmo. Mas há uma diferença entre essas intenções: a primeira é não-consciente, enquanto que a última é consciente. Então, qual seria a diferença no seu papel causal na produção da ação? A consciência de uma intenção seria supérflua? Assim, isso suscita a questão de como poderia haver essa diferença de consciência sem que haja nenhuma diferença na forma como as intenções causam ações.

Propomos a seguinte solução: pode haver um paralelo entre intenções e como o experimento de piscada atencional desenvolvido por Sergent et al. explica que os estímulos visuais sejam conscientes em algumas sessões e não-conscientes em outras. É possível que os processos que realizam a intenção de fazer A sejam ou não ativados com intensidade suficiente para atingir o limiar que permite sua difusão para outras áreas do sistema. Quando uma intenção vencesse a concorrência para mobilizar este espaço de trabalho, a intenção se tornaria consciente, quando não, ela permaneceria não-consciente. No entanto, mesmo

\footnotetext{
${ }^{70}$ No sentido de que a consciência não seria necessária para que o agente tivesse capacidade de agir, ou de controlar sua ação.

${ }^{71}$ Aqui traduziremos broadcast por difundir.
} 
intenções não-conscientes continuariam a ser processadas (assim como na percepção), ${ }^{72}$ o que permitiria que essas intenções ainda desempenhassem o seu papel em causar a ação.

No entanto, de acordo com Dehaene et al. (2006), atingir certo grau de ativação não é o único requisito para atingir a consciência. Para que haja consciência, a ativação deve ser estendida ao longo de conexões de longa distância até áreas associativas altamente interconectadas que farão a informação reverberar até diferentes áreas do sistema. Assim, a reverberação de informações por diferentes áreas é considerada importante para a consciência, porque mantém a informação on-line por um longo período, mesmo depois que sua origem não esteja mais disponível. Isso permite outra característica importante da consciência de acordo com Dehaene et al.: a propagação de informação para diversos sistemas.

A competição pela área de trabalho poderia explicar a consciência, ou falta dela, em diferentes intenções, além de tornar possível uma explicação plausível de como estados mentais se tornam conscientes, e de qual função a consciência desses estados mentais poderia desempenhar. Enquadradas no contexto da TEG, ativação e concorrência pela difusão de informação, cuja capacidade seria limitada, explicariam como algumas intenções se tornam conscientes e outras não, e como, mesmo quando não são conscientes, intenções contribuem causalmente para a produção de ações. Igualmente, recrutar outros sistemas para executar a intenção explicaria a função da consciência de intenções nos casos em que esses estados mentais são conscientes.

Baars (1988) sugere algumas situações em que a consciência pode ser necessária, de acordo com a função sugerida acima: no aprendizado, em ações complexas que não fazem parte do repertório do agente, em novos eventos, e na formação de novas formas de conexão entre coisas já conhecidas. Essas situações requereriam interações novas e inesperadas entre processadores, criando a necessidade da interação entre diferentes sistemas de processamento. Já Wegner (2003) propõe que a função da consciência seria informar o agente daquilo que ele vai fazer. ${ }^{73}$

Então, se imaginarmos que uma agente assiste a um vídeo que ensina a fazer um tipo de nó, e ela tem a intenção de fazer o nó, é possível supor que ela executará a tarefa apenas se ela tiver consciência da produção de cada movimento para fazer o nó. De acordo com a

\footnotetext{
${ }^{72}$ Serget et al. observaram que nas sessões em que houve piscada atencional, N3 apresentou intensidade reduzida, o que sugere que o processamento não-consciente de $\mathrm{T} 2$ ocorreu mesmo nas sessões em que não houve visibilidade de T2. Com efeito, seu processamento ocorreu ao mesmo tempo em que o processamento de T1 estava acontecendo conscientemente.

${ }^{73}$ Como a função da consciência se tornou uma discussão importante para os críticos de Wegner, ele explicou as possíveis funções da consciência em Self is Magic (2008). Nesse artigo Wegner esclarece que a consciência teria as funções de sinalização social, alocação social, e controle social.
} 
Hipótese de Difusão, esse é o caso porque a execução dessa intenção precisaria da difusão dessa intenção para recrutar processadores que ajudarão a executá-la. A hipótese em questão também explica porque a produção de algumas ações seria consciente para algumas pessoas, mas não para outras. Um marinheiro habilidoso, que sabe como fazer o nó poderia ser capaz de fazê-lo bem enquanto absorvido por pensamentos sobre seus problemas domésticos. Isso porque os processadores relevantes já estão conectados devido às experiências passadas do agente, assim, a consciência não precisaria desempenhar o seu papel de arregimentação.

A hipótese da difusão também explica porque decidir parece ser sempre uma ação consciente. Agentes tomam decisões em face de uma incerteza prática, que eles não sabem como resolver (MELE, 2003; MARQUES, 2015). Essa é sempre uma situação nova para a qual o agente não tem uma rotina planejada que lhe mostre o que fazer naquela situação. Sendo esse o caso, isso também explicaria por que alguns teóricos da CA consideram decisões como sendo a marca da agência (O’CONNOR, 2000). Afinal, decidir ${ }^{74}$ é uma ação consciente; nesse sentido, decisões ajudariam a garantir que o agente desempenhe um papel na produção de sua ação, para teorias que consideram que a consciência é relevante para que o agente desempenhe um papel importante na produção da sua ação.

Por outro lado, nas ações overlearned-que o agente automatizou ou quase automatizou — a intenção correspondente não precisaria ser difundida, porque as conexões relevantes já estariam formadas. Com efeito, se o agente tentar manter-se consciente delas, ele retardará sua execução. Isso explicaria por que eu muitas vezes não tenho consciência de produzir minha ação de colocar as chaves na minha bolsa antes de sair de casa. Quando isso ocorre, eu procuro minhas chaves antes de perceber que eu já as tenho na bolsa. O mesmo pode ser o caso para um guitarrista habilidoso, que pode tocar uma música que ele conhece bem sem a necessidade de interromper a conversa que está tendo.

O tipo de difusão de informação proposta por TEG poderia ser útil para o planejamento de ações. A distribuição de informação sobre uma intenção do agente permitiria a melhor coordenação com outras intenções que o agente tivesse no momento; por exemplo, intenções que envolvam outros processadores. Bratman (1999) defende a tese de que planos têm a importante função de coordenação, o que evitaria conflitos entre diferentes intenções, incompatíveis entre si, e a função de planejamento de ações futuras, a fim de permitir que os objetivos planejados sejam alcançados. Intenções futuras seriam os tijolos dos quais o planejamento de agentes racionais seria constituído, pois, assim como no caso de nossas

\footnotetext{
${ }^{74}$ Pelo menos no sentido estrito, quando envolve deliberação.
} 
crenças (1987, p. 08), nós tenderíamos a ajustar nossas intenções para que eles sejam consistentes umas com as outras. Embora não estejamos conscientes de todos os detalhes desse planejamento, provavelmente estamos conscientes de planejar intenções centrais que envolvem sub-planejamento no sistema adequado. A difusão da informação sobre intenções imediatas e futuras poderia ajudar a coordená-las e evitar conflitos.

Ademais, é possível que o limiar de ativação varie conforme as intenções, assim como Dehaene et al. sugerem no caso de percepção. O limiar seria reduzido para percepções, devido à atenção ao estímulo, ou ao conteúdo emocional da percepção. Do mesmo modo, o limiar de ativação para que uma intenção seja difundida no sistema poderia ser reduzido conforme o plano ao qual ela estivesse incorporada, no caso em que o plano seja complexo ou importante para um plano mais geral, por causa de seu conteúdo emocional, ou por entrar em conflito com o sistema de valores do agente. O resultado seria que a difusão se tornaria mais fácil, o que explicaria a variação do grau de consciência entre intenções semelhantes do agente em diferentes momentos.

A Hipótese de Difusão proposta aqui é uma hipótese em princípio testável que propõe uma explicação para como a consciência de intenções poderia variar. Essa proposta visa responder à objeção de Wegner à noção de que estados mentais conscientes não poderiam desempenhar um papel causal na produção de ações, além de sugerir uma explicação para a eficácia causal da consciência de intenções. Pois, como foi discutido acima, seria difícil explicar como essa consciência poderia não fazer qualquer diferença na produção causal das ações, tendo em vista que essa é uma diferença relevante entre as intenções. Deve haver até mesmo uma distinção temporal entre elas, pois a produção consciente de uma ação deve requerer mais tempo do que a produção não-consciente de uma ação.

A Hipótese da Difusão diz que a consciência da produção de ações pode variar. Então ela implica que há intenções conscientes e intenções não-conscientes. Assim, se essa hipótese for aceita a consciência de uma intenção não pode ser considerada uma condição necessária para a produção da ação. ${ }^{75}$ A hipótese também exclui que a consciência possa desempenhar uma função de supervisão dessa produção. Assim, deve ser revista a concepção de que um agente é uma entidade que poderia produzir sua ação através de sua vontade consciente - o que Wegner questiona - ou que poderia, por meio da consciência, controlar e interferir na produção de suas ações. Em um sistema distribuído como o que está sendo proposto não há

\footnotetext{
${ }^{75}$ Ou para o controle sobre a ação, como a CA esperaria (vide próxima sessão).
} 
uma central de supervisão consciente. As ações de um agente são causalmente produzidas e guiadas pelos estados mentais relevantes, da forma adequada.

A hipótese proposta está de acordo com a tese de Wegner de que o aspecto consciente da produção da ação não é a causa da ação humana; não está relacionada a uma vontade originadora da experiência da agência. Porém, Wegner parece definir a noção de agente como requerendo a consciência, o que o obriga a dizer que, já que a consciência não participa da produção de nossas ações, então não seríamos agentes. Esse, no entanto, não é um problema para a Hipótese de Difusão, pois a hipótese apresentada aqui acomoda a ideia de que os agentes podem nem sempre estar conscientes de suas intenções e, ainda assim, ser agentes. Os processos não-conscientes que participam da produção das ações não são uma ameaça para a noção de agência; estes são partes importantes dessa produção, de acordo com a Hipótese de Difusão; afinal, esses processos seriam a maior parte do nosso processamento. ${ }^{76}$

\section{O desaparecimento do agente e controle regulativo}

Nessa seção será argumentado que a razão pela qual Wegner afirma que não há um agente na produção da ação se deve à sua defesa de que não há estados mentais conscientes na produção causal da ação. Isso revela que o autor associa a noção de agência ao papel da consciência nessa produção. Nesse sentido, sua concepção de agência se parece com a dos teóricos da CA, o que reflete na preocupação da última no problema do DA. Pois o DA surge de uma concepção específica de agentes, e de qual deve ser seu papel na produção das ações. O ponto defendido é que agência não requer consciência.

Embora colocada de forma diferente, a noção defendida por Wegner de que temos a ilusão de que somos agentes compartilha certas semelhanças com o DA. Nessa seção será discutida a concepção de agentes associada com seu processamento consciente, principalmente na CA, mas sem se limitar a ela (VELLEMAN, 1992; O'CONNOR, 2000; STEWARD, 2012). A esse tipo de concepção envolve a consciência como requisito para a agência. Essa discussão expõe como a participação consciente na produção de ação é fundamental para as teorias que propõem a objeção ao DA. A consciência desempenha um

\footnotetext{
${ }^{76}$ Bernard Baars atribui isso à capacidade de processamento limitada da consciência.
} 
papel importante na visão da CA porque garante uma espécie de controle considerado importante nessa teoria.

Nas teorias da CA, se o agente não causa sua ação no sentido especial de causa substancial, em que a teoria supõe que agentes produzam suas ações, a ação não é considerada uma produção do agente (CHISHOLM, 1978; O’CONNOR, 2000; LOWE, 2008). Supomos que Wegner somente aceitaria que somos agentes se nossas ações fossem produzidas pela vontade consciente. ${ }^{77}$ Nesse sentido, a CA acusa a TCA de fazer o agente desaparecer da produção de ação, visto que a TCA não requer que a vontade consciente participe da produção causal das ações.

A CA exige que o agente tenha uma espécie de controle que garanta que ele pudesse ter agido de forma alternativa à que ele agiu. Esse controle garantiria que o agente tivesse relevância na produção da ação. Isto é o que John Martin Fischer (1994) chamou de controle regulador, que depende da fiscalização consciente do agente sobre suas ações. Se o agente não puder controlar sua ação, ele não tem um papel na produção de sua ação.

Isso suscita dúvidas a respeito das ações automáticas e se as mesmas podem se encaixar nessa exigência quanto ao papel do agente. Por exemplo, quando um agente freia antes de perceber que um gato correu para o meio da rua, ele não poderia ter evitado fazê-lo por causa de sua formação como motorista, que automatizou sua ação de frear ao menor sinal de qualquer obstáculo na estrada. Sua ação ocorre antes dele perceber conscientemente o que correu na frente de seu carro. Assim, mesmo se ele odiasse gatos de uma forma doentia e tivesse preferido executar o animal, ele teria freado antes que pudesse perceber que se tratava de um gato.

O motorista teria que ter sido capaz de conscientemente vetar sua ação de frear para que a teoria da CA considerasse que ele teve um papel relevante na ação. Esta estória mostra que em teorias da CA o controle regulador é necessário para que a teoria aceite que o agente tenha um papel na produção de sua ação. ${ }^{78}$ Enquanto que a TCA não requer esse tipo de controle para que se considere que o agente tenha um papel na produção de sua ação, porque os estados mentais que desempenham um papel causal na produção da ação são estados

\footnotetext{
${ }^{77} \mathrm{O}$ que Wegner afirma ser uma ilusão, apesar de defender que essa ilusão pode ter suas próprias funções (WEGNER, 2008).

${ }^{78}$ Podemos supor, no entanto, que Wegner não veria razão para dizer que a experiência consciente de controle que temos não é também uma ilusão. Afinal, ele não atribui qualquer papel aos estados mentais conscientes na produção de ação.
} 
mentais do agente, mesmo que não-conscientes. Por outro lado, a teoria pode exigir controle de outro tipo ${ }^{79}$ para atribuir responsabilidade sobre uma ação.

Sem controle regulador, alguns teóricos da CA considerariam a ação não-livre, como se a ação fosse produzida por forças externas que não fossem do agente. Timothy O'Connor (2002) é um exemplo desses teóricos, pois O'Connor não aceita que um agente pudesse ignorar que tem uma intenção: "O que dizer do caso limite-ignorância consciente total da intenção em ação? Aqui, eu acho, o teórico da agência deve dizer $-\mathrm{o}$ que é independentemente plausível—que não se age livremente. Eu, de qualquer forma, sou incapaz de conceber um agente diretamente controlando sua própria atividade sem qualquer consciência daquilo que o esteja motivando" (O'CONNOR, 2002, 88), a menos que o agente não tenha controle sobre sua ação.

$\mathrm{Na}$ teoria de O'Connor, a fim de controlar sua própria atividade, o agente deve estar consciente de alguns dos estados mentais que o motivam a agir. Portanto, a falta de consciência dessas motivações envolvidas na produção da ação resultaria na falta de controle do agente sobre a ação. A suposição de que a liberdade do agente é garantida pela produção consciente de sua ação é uma das razões pelas quais as teorias da causalidade do agente defendem que em ações produzidas sem que o agente estivesse consciente dessa produção (ou seja, em que ele não tivesse controle regulador), faltaria um papel para o agente nessa produção. ${ }^{80}$ Pois associamos a falta de liberdade na ação a quando algo externo ao agente produz a ação, ou a quando o agente não tem suficiente controle sobre sua ação para ter agido de outro modo. Assim, o DA é suscitado, o que equivaleria ao agente não ter um papel relevante em produção de sua ação.

É razoável supor que nem toda ação humana seja produzida com o mesmo grau de controle. Algumas não alcançam os critérios para serem consideradas ações no sentido robusto do termo ${ }^{81}$ (VELLEMAN, 1992), que aqui serão chamadas de ações robustas. Sabemos que muitas vezes agimos automaticamente, ou somos influenciados por forças

\footnotetext{
${ }^{79}$ Alguns partidários da TCA acreditam que o controle para guiar a execução da ação é importante para que o agente seja responsável por sua ação. Para que um agente tenha controle para guiar sua ação é necessário que os mecanismos que causam a ação respondam às razões do agente, em certa medida. Ver John Martin Fischer (1994).

${ }^{80}$ Para Roderick Chisholm (1978, p. 622-23), o problema de reduzir asserções sobre uma ação empreendida por um agente a uma explicação envolvendo causalidade de eventos não está apenas em reduzir a causalidade do agente a asserções em que eventos desempenhem o papel causal. O problema é fazê-lo perdendo o sentido de que o agente fez A, sem dar conta do fato de que o agente poderia ter feito outra coisa. De acordo com Chisholm, a redução deve ser feita de uma forma que deixe em aberto a possibilidade de que o agente poderia ter feito outra coisa, concedendo assim seu controle sobre sua ação. Assim, podemos concluir que o tipo certo de controle, controle regulador, evitaria que o agente desaparecesse no caso de uma redução bem sucedida.

${ }^{81} \mathrm{O}$ que Velleman (1992) chama de full-blooded action.
} 
externas, como quando um agente embriagado pisoteia as flores do jardim do vizinho ao tentar chegar a sua casa. No entanto, no debate sobre o papel do agente na produção de ações, as ações robustas teriam uma característica distintiva.

Isso fica claro na discussão de David Velleman (1992) a respeito do problema do DA. Apesar de não ser um teórico da CA, Velleman não acredita que uma explicação de ações que envolva apenas os estados mentais do agente como causa das ações possa explicar ações robustas e sua característica distintiva:

\begin{abstract}
Quando meus desejos e crenças engendraram a intenção de terminar a amizade, e quando essa intenção desencadeou o meu tom desagradável, eles estavam exercendo os mesmos poderes causais que eles exercem em casos ordinários, e mesmo assim eles estavam fazendo isso sem qualquer contribuição minha. Assim, o que constitui a minha contribuição, em outros casos, não pode ser que essas atitudes estejam manifestando seus poderes causais comuns. (VELLEMAN, 1992, 465)
\end{abstract}

Velleman acredita que: 1) pode haver ações com as quais o agente não se identifique que sejam causadas por seus estados mentais, sem desvios; 2) enquanto que o agente pode se identificar com outras ações produzidas da mesma maneira; 3) então, a participação do agente na sua ação não se deve simplesmente aos estados mentais que causam a ação, mesmo que a causação ocorra do modo normal (sem desvios). O agente deve poder influenciar suas motivações.

De acordo com Velleman, o que faz com que uma ação seja robusta é que o agente tenha um desejo de agir de acordo com razões. Isso deve contribuir para influenciar suas motivações, de modo que a balança penda a favor da razão do agente que seja a razão mais forte para se agir de acordo. E isso permitiria ao agente exercer controle sobre o que ele faz. $\mathrm{O}$ desejo exerceria a função do agente na produção da ação e direcionaria o pensamento do agente para suas motivações: "Dizemos que o agente direciona seus pensamentos para os vários motivos que lhe dão motivo para agir; mas, na verdade, os pensamentos do agente são direcionados nessa direção pelo desejo de agir em conformidade com razões” (VELLEMAN, 1992, 479). Portanto, sua ação seria uma ação robusta sempre que esse desejo direcionasse o pensamento do agente para suas motivações para agir, porque esse desejo seria o agente funcionalmente.

Assim, o que estaria faltando na explicação de ação proposta pela TCA é que o agente tivesse um papel na produção da ação (que seria o papel desempenhado pelo desejo de agir de acordo com razões na teoria de Velleman), e fosse capaz de alterar sua ação, e a falta disso 
suscitaria o problema do DA. Isso é um consenso entre a compreensão do problema por Velleman, que não rejeita a TCA, e pela CA. Isso envolve a suposição de que o agente deve ter controle direto sobre sua ação, ou para originá-la ou para mudá-la, ${ }^{82}$ o que implicaria estar consciente dessa produção (ou, pelo menos, potencialmente consciente).

Nesse contexto, o controle regulador do agente sobre suas ações é visto como necessário, juntamente com a suposição de que o agente deve estar consciente pelo menos de que está produzindo a ação para que seja possível dizer que ele tem um papel na sua produção. Isso está de acordo com a conclusão de Wegner de que se as ações são causalmente produzidas por atividades inconscientes (como ele defende que são), não haveria espaço para o agente na produção das ações.

\section{Agentes e seu papel na produção de ações}

Teóricos da CA acusam a TCA de não ser capaz de explicar ações produzidas por um agente humano. No entanto, é curioso afirmar que o agente não tem um papel na produção de sua ação, porque a ação é causalmente produzida pelos estados mentais do agente; afinal, trata-se dos estados mentais do agente. Presumivelmente teóricos da CA esperam que o agente desempenhe um papel consciente na produção da ação e que ele tenha controle regulador sobre a mesma, o que não faz parte das propostas de TCA.

Ademais, se o problema em questão é que na explicação proposta pela TCA o agente não desempenharia um papel na produção da ação, é preciso esclarecer o que se quer dizer por agente e por seu papel na ação. Se para que se seja o agente de uma ação, a CA requer que a ação seja causada pelo agente ele mesmo, fica parecendo que o agente é algo diferente de seus estados mentais. Assim, é necessário compreender qual seria a concepção de agente para que se possa compreender a objeção do DA. Igualmente, é importante saber qual seria o papel esperado para o agente na produção da ação, de acordo com CA.

O desacordo sobre o que conta como uma ação do agente e o que numa explicação de ações faz com que o agente desapareça se deve a um desacordo mais fundamental entre a CA e a TCA: um desacordo sobre o que é um agente. Por causa da preocupação com o controle, a teoria da causalidade do agente associa agentes com o aspecto consciente dos seres humanos;

\footnotetext{
${ }^{82}$ Como defende Steward (2012).
} 
assim, ela separa o agente de suas atividades que não estão sob sua governança consciente. Ao mesmo tempo, parece que essa concepção supõe que a consciência desempenharia o papel de um sistema de supervisão que coordenaria e dirigiria as ações do agente.

O que faz correto, me parece, atribuir os movimentos a mim-o que os torna
movimentos voluntárias meus em vez de, digamos, respostas por reflexo
sobre os quais eu não tenho nenhum controle significativo é que os
sistemas relevantes estão, em última análise, subordinados a sistemas de
nível pessoal, conscientes numa hierarquia bem integrada cujo objetivo geral
é garantir que eles funcionem, de modo geral, para servir meus objetivos
conscientes, embora, naturalmente, possa acontecer em ocasiões individuais
que não haja nenhum objetivo ou propósito em um determinado output
individual de tal sistema. A subordinação tem muitos aspectos. Eu posso
escolher a qualquer momento tornar o funcionamento dos sistemas
subordinados relevantes o foco da minha vontade consciente. (STEWARD,
2012, 51)

A fim de fazer isso, o agente deve ser integrado ao seu corpo de modo que ele desempenhe um papel irredutível na atividade motora do organismo (STEWARD, 2012, 18), o que envolveria a capacidade de determinação de-cima-para-baixo de seu movimento, que estaria acima dos processos acontecendo no interior do organismo que produzem o movimento do corpo (STEWARD, 2012, 17-18). A determinação de-cima-para-baixo proposta por Steward significaria um sistema centralizado que conscientemente determinaria os movimentos a serem executados; nesse sentido o agente poderia interferir conscientemente em sua produção de ações. Isso equivaleria a ter o tipo de controle que os teóricos da CA valorizam na sua concepção da agência humana.

Nesse sentido, a CA requer um sistema consciente centralizado que produziria ou monitoraria as ações do agente, enquanto a TCA poderia envolver um sistema mais distribuído, como foi sugerido pela Hipótese da Difusão. Por exemplo, Steward (2012) afirma que o agente não pode ser reduzido a partes de si mesmo.

Uma resposta a essa pergunta vai exigir também uma compreensão do que poderia nos levar a querer dizer que um organismo, em vez de apenas uma parte de um, ou algum processo dentro de um, fez algo acontecer, e de como a causalidade, assim efetuada (a causalidade que é a agência) se relaciona à causalidade envolvida nos processos sub-pessoais que a tornam possível. (STEWARD, 2012, 12)

De acordo com este ponto de vista, agentes são contribuintes diretos dos mecanismos de ação; portanto, são contribuintes cruciais para fazer a ação acontecer: 
[...] parece que estamos diante de uma espécie de agência que pertence de maneira mais profunda à entidade em questão, de modo a que a entidade não é mais apenas a coisa que abriga os mecanismos relevantes de produção do movimento, mas é pensada como sendo ela mesma uma colaboradora crucial para esses mecanismos. O determinante crucial, para mim, para se podemos dizer que uma criatura verdadeiramente é uma auto-movedora, tem a ver com se haveria algum papel irredutível a ser desempenhado na explicação da atividade motora do organismo por certo tipo de integração que eu acredito que seja parte integrante do funcionamento da maioria dos animais de certo grau de complexidade, um tipo de integração que eu tentarei caracterizar ao final deste livro. (STEWARD, 2012, 17)

O que distingue essas entidades que têm corpos de outras entidades é que elas têm mentes, e mover o corpo de acordo com sua vontade envolve ter objetivos e um ponto de vista subjetivo do mundo.

Entidades com uma mente é tentador dizer-e, na verdade, de certa forma eu acredito que a questão a respeito de quais entidades têm mentes e quais têm corpos deveriam propriamente ser consideradas como sendo a mesma questão [...] envolve, pelo menos, a aplicabilidade da rudimentar ideia psicológica de objetivos, uma tentativa e um ponto de vista subjetivo do mundo. (STEWARD, 2012, 18)

Steward iguala o agente a um sistema consciente de nível pessoal, que supervisiona os processos de produção de ação e os mantém em acordo com seus objetivos conscientes, de modo que o agente poderia direcionar sua supervisão consciente para qualquer um desses, sempre que ele quisesse ou achasse necessário. Esse tipo de controle do agente permitiria que ele desempenhasse um papel na produção de sua ação. Mesmo que o movimento não seja produzido conscientemente, para que o agente tenha um papel nele, o movimento deve ser parte do sistema que está sob sua supervisão consciente em potencial. ${ }^{83}$ Pois os sistemas que produzem a ação são subordinados a uma hierarquia consciente que coordena as ações para que elas sejam empreendidas visando atingir objetivos conscientes do agente.

"Sou eu quem em primeiro lugar permite, ou não, que os sistemas sub-pessoais relevantes comecem a operar" (STEWARD, 2012, 52). Nesse sentido, o agente tem o movimento sob seu controle, e ele pode conscientemente interferir na ação a qualquer momento. O sistema de nível-pessoal permite ou impede a atuação de sistemas sub-pessoais. Assim, nessa teoria, a consciência desempenha um papel importante em garantir que o agente desempenhe um papel na produção da ação, porque a consciência garante o controle do agente

\footnotetext{
${ }^{83}$ Este sistema nem sempre intervém na produção da ação, nem origina as ações. Ao invés disso, seu papel de supervisão é intervir quando considerado necessário, exercendo assim controle em potencial sobre todas as ações do agente.
} 
sobre sua ação. Os movimentos do agente não estão sob seu controle no sentido de que ele conscientemente e diretamente originaria cada movimento. Esses estão sob seu controle no sentido de que ele poderia diretamente e conscientemente mudar seus movimentos.

Assim, considera-se que o agente não desempenha um papel na produção de qualquer movimento corporal que esteja fora do escopo do controle em questão. No entanto, alguns movimentos não estão sob a supervisão consciente, como reflexos musculares, ações automáticas, batimentos cardíacos ou movimentos peristálticos. De acordo com os critérios de Steward, reflexos e ações automáticas não seriam considerados ações atribuíveis ao agente.

É estranho afirmar que ações automáticas não sejam atribuíveis ao agente. Pensemos num exemplo: um garoto, Sam, acostumou-se com uma brincadeira de mau gosto que seus colegas de escola gostam de pregar-lhe, sempre que suco é servido em um copo na hora do almoço. As crianças tentam bater no copo na sua parte inferior, para fazer com que o copo vire e derrame a bebida contida nele sobre Sam. Sam sabe que ele não deve se distrair enquanto tem um copo em suas mãos; ele até mesmo elaborou um plano. Sempre que um de seus colegas de classe se aproxima dele enquanto ele está segurando seu copo de suco, Sam se prepara e lança o conteúdo do copo em seu atacante logo que a outra criança move a mão em sua direção. Depois de um tempo Sam torna-se tão bem treinado em sua técnica que o movimento é automatizado; se alguém move a mão em direção ao copo de Sam, ele age imediatamente. Seu treinamento chegou ao ponto em que se Sam quisesse abortar a açãopor exemplo, porque o diretor se aproxima - ele lançaria o suco antes que ele pudesse evitar fazê-lo. Os colegas de Sam já não o incomodam quando ele está comendo seu almoço, e Sam está satisfeito.

De acordo com a teoria de Steward, no entanto, Sam não teria desempenhado um papel causal relevante na produção da sua ação, porque ele não teve o controle consciente considerado importante em sua teoria. Essa conclusão valeria mesmo essa tendo sido uma ação que Sam treinou para ser capaz de realizar rapidamente e com precisão, e mesmo estando em conformidade com seus desejos e planos (se sua ação foi louvável é uma questão diferente). Uma vez que ele se esforçou para automatizar seus movimentos, parece estranho dizer que Sam não desempenhou um papel relevante na produção da ação, apenas porque ele não teria capacidade (consciente) de modificá-la, o que não quer dizer que a Sam não tenha tido consciência do seu treinamento enquanto treinava e planejava a automatização dessa habilidade. Afinal, a situação desencadeia uma resposta rápida, como Sam havia planejado.

A suposição de Steward a respeito do controle necessário para garantir que o agente desempenhe um papel na produção da ação deixa de fora ações que, mesmo que o agente não 
tenha controle regulador sobre elas, consideraríamos um resultado de seu próprio treinamento; de forma que não consideraríamos que o agente esteja ausente dessa produção. A ação está demasiadamente enraizada em seus valores, desejos e planos para não ser considerada uma produção do agente.

Isso indica que a concepção do que são agentes na teoria dá o tom para quais ações serão atribuídas a ele e de acordo com quais critérios. Por isso as teorias da CA não aceitam a explicação da TCA para ações, porque a última teoria explica ações sob uma concepção diferente de agentes, que não exige o mesmo tipo de controle fundamentado num papel de supervisão desempenhado pela consciência. Assim, a TCA tem critérios diferentes para o papel do agente na produção de ações. De seu ponto de vista, a CA espera demasiado controle consciente na produção das ações.

$\mathrm{Na}$ teoria de Steward, o papel do agente em uma ação requer supervisão consciente da produção de ação, mesmo que apenas potencialmente. Wegner parece ter uma concepção semelhante de agentes. Ele nega que sejamos agentes, assim, é possível supor que para sermolo nós teríamos que ser o tipo de entidade cuja experiência de conscientemente causar nossas ações não seria uma ilusão. Como ele não crê que seja esse o caso, Wegner nega que sejamos agentes; afinal, de acordo com sua teoria, a experiência consciente de causar nossas ações não tem relação com a forma como as nossas ações são realmente produzidas; apenas temos a ilusão de que elas são produzidas dessa maneira. ${ }^{84}$

Wegner não está preocupado com o controle consciente no sentido em que as teorias da CA estão. ${ }^{85}$ No entanto, ambas as teorias estão preocupados com a consciência na produção ação. Porém, Wegner eleva o requisito para a agência muito acima da capacidade de produzir ações que ele concede aos seres humanos; a ponto de os critérios se tornarem inalcançáveis em sua teoria. No entanto, nós temos mais razões para pensar que essa concepção de agência está equivocada do que para pensar que os seres humanos não são agentes e nunca causam o que eles fazem. Essa concepção de agência precisa ser revisada.

Do mesmo modo, a concepção de agentes da CA envolve requisitos mais difíceis de alcançar do que a concepção de agentes da TCA. A primeira requerer controle consciente para que o agente desempenhe seu papel na produção de sua ação. No entanto, o papel que a CA espera que o agente desempenhe nas explicações de ações é pouco realista; pois, como foi

\footnotetext{
${ }^{84}$ De acordo com Wegner, a consciência não governa tudo o que fazemos, nem estamos cientes de tudo o que fazemos. O processamento consciente é bastante lento em comparação com o processamento inconsciente, e está ausente da maioria das nossas ações que envolvem reações rápidas, bem como as ações feitas automaticamente ou sob o efeito da hipnose.

${ }^{85}$ Há também teorias da CA que propõem que o agente origina sua ação conscientemente por meio da vontade consciente ou decisão (LOWE, 2008, O’CONNOR, 2000).
} 
explicado pela teoria de Wegner, a consciência provavelmente não tem um papel tão proeminente de governança como espera a CA. ${ }^{86}$

Uma hipótese diferente para o papel da consciência de um estado mental foi proposta - a Hipótese de Difusão - e se for aceita, é necessário lembrar que ela não acomoda a visão que associa a consciência com o controle sobre as ações, nem com o papel do agente na produção de ação. A hipótese em questão atribui um papel à consciência na produção de ações, especificamente à consciência das intenções imediatas ${ }^{87}$ (vide a seção 6). Desse ponto de vista, a concepção de agentes da CA, que considera o agente como sendo uma entidade que causa suas ações e que tem controle regulador sobre ela, é uma concepção equivocada. A partir desta concepção pouco realista surge o DA. O agente só desaparece porque é concebido de uma forma que deve ser revista, porque essa concepção requer controle consciente, o que não é possível para os seres humanos.

\section{Considerações finais}

A hipótese aqui apresentada é uma possível explicação para como intenções podem ser conscientes em algumas produções de ação e não-conscientes em outras; por exemplo, em ações automáticas. Foi proposto um paralelo com a percepção; a consciência das intenções poderia depender de um limiar de ativação, a fim de permitir o recrutamento de outros sistemas para executá-la por meio da difusão, como foi sugerido ser o caso nas percepções. Essa explicação permite que a consciência das intenções desempenhe um papel importante na explicação das ações. Isso é relevante porque a partir de uma perspectiva evolucionista seria difícil conceber que desenvolvemos este tipo de consciência sem que ela tenha qualquer função, ou para que ela nos iluda a respeito da produção de nossas ações.

A hipótese em questão também contribui para esclarecer que a função da consciência desse estado mental na produção de ações poderia envolver a difusão de informações e o recrutamento de sistemas necessários para a execução da intenção em questão. Isso expõe a incompatibilidade dessa hipótese com a exigência da teoria da CA de que o controle consciente da ação tenha um papel importante na produção de ação. Essa exigência também é incompatível com os argumentos de Wegner de que a vontade consciente não desempenha um

\footnotetext{
${ }^{86}$ Já que Wegner afirma que a vontade consciente não contribui causalmente para a produção de nossas ações.

${ }^{87}$ Intenção de agir imediatamente, não no futuro.
} 
papel relevante na produção das ações humanas. Assim, chegamos à conclusão de que a concepção de agentes da teoria da CA deve ser revista. 


\section{Capítulo IV - A Noção de Agência na Teoria da Causalidade do} Agente

\section{Introdução}

O problema do Desaparecimento do Agente (DA) brota de uma suposição a respeito de determinado papel que se espera que o agente desempenhe na produção de suas ações. A teoria da Causalidade do Agente (CA) afirma que o agente deve participar da produção de sua ação, e por isso a explicação da Teoria Causal da Ação (TCA) a respeito de ações não poderia dar conta dessa participação. Se os estados mentais do agente produzissem causalmente sua ação, o seu papel se perderia no fluxo dos eventos (NAGEL, 1987). Alguns teóricos da CA acreditam que não haveria intervenção suficiente do agente na ação, se seus estados mentais produzissem suas ações, porque o agente não desempenharia nenhum papel nessa produção. ${ }^{88}$ Assim, a CA espera que o agente seja ativo, e de alguma forma influencie diretamente a produção de sua ação de uma maneira que mostre seu envolvimento na mesma.

No entanto, pode ser que agentes humanos não sejam capazes de desempenhar o papel esperado pela CA. O agente humano é um ser humano, de modo que as suas capacidades são as capacidades de um ser humano. Foi argumentado no último capítulo que a concepção de agentes que é cara para a CA traz expectativas que são difíceis para seres humanos suprirem. Por outro lado, uma concepção mais modesta de agentes poderia incluir o papel do agente em sua ação, sem fazer do agente algo separado de seus mecanismos de ação, ou esperar que ele seja capaz de diretamente controlar suas ações. Neste capítulo será argumentado que, abaixando os critérios para o que consideramos agentes, o problema do DA perderia sua força.

Essa discussão pretende expor as pressuposições da CA sobre o que são agentes. $\mathrm{Na}$ seção seguinte, a concepção de E. J. Lowe (2008) a respeito da relação entre o agente e seu corpo será questionada, e essa discussão será estendida para as teorias da CA em geral, uma

\footnotetext{
88 A.I. Melden (1991), Helen Steward (2012), Roderick Chisholm (1964) e até mesmo Paul Ricoeur (1990) defendem que ações requerem causalidade do agente, uma vez que é algo que o agente faz acontecer. Enquanto isso, Timothy O'Connor (2000) e E.J. Lowe (2008) sustentam que a causalidade característica do agente é necessária para ações livres, mas eles não descartam que ações possam ser produzidas causalmente por eventos mentais.
} 
vez que é o suposto papel do agente nas ações que está sendo questionado. Assim, defenderemos que o pressuposto de que o agente é uma entidade que controla diretamente suas ações está equivocado.

\section{Discussão preliminar: a concepção de agente na CA}

Como agentes são concebidos tem grande influência sobre o tipo de teoria que a CA propõe a fim de garantir que o agente tenha o papel que a teoria espera que ele tenha, i.e., de diretamente iniciar suas ações ou intervir nas mesmas. No entanto, defenderemos na próxima seção que a concepção de agentes dessa teoria está equivocada. Contudo, em primeiro lugar, a concepção de agentes da CA será discutida. Nessa seção as concepções de E.J. Lowe (2008) e Helen Steward (2012) serão apresentadas. Isso deve ajudar a entender a concepção de agentes da CA, bem como as pressuposições sobre o agente. Uma vez que essa concepção de agentes tenha sido apresentada, será possível discutir se esse conceito se encaixa com o que sabemos sobre as capacidades humanas (supondo que os seres humanos são agentes) e nossa produção de ações.

Em nosso uso comum da palavra, quando falamos em agentes estamos nos referindo a algo que desempenha um papel ativo na produção de ações. O termo é usado principalmente para pessoas e, talvez, animais; mas não tanto para objetos inanimados. Por vezes, pode-se dizer que um produto químico foi o agente de uma reação quando ele entrou em contato com outro produto químico; no entanto, isso não significa que estejamos usando o termo no mesmo sentido em que o usamos quando dizemos que Sara foi a agente de uma ação.

$\mathrm{Na}$ filosofia da ação este conceito faz parte do debate a respeito de como os agentes agem, e as suposições a esse respeito dão os contornos para qual tipo de explicação de ações é aceita. Foi visto no capítulo anterior (seções 7 e 8) que, para Helen Steward (2012), agentes são donos de seus corpos. Eles são capazes de auto-movimento [self-movement], o que se encaixa com o incompatiblismo; ${ }^{89}$ porém, esses movimentos não podem ser reduzidos à vontade do agente. Isso significa que os agentes são capazes de determinar suas ações de-

\footnotetext{
${ }^{89}$ Grosso modo, o incompatibilismo é a teoria que defende que se o determinismo for verdadeiro, então não há livre arbítrio; i.e, o determinismo seria incompatível com o livre arbítrio. Já o compatibilismo aceita que se o determinismo for verdadeiro isso não necessariamente quer dizer que o libre arbítrio seja impossível.
} 
cima-para-baixo. Essa determinação operaria acima dos processos que ocorrem dentro do organismo que produzem o movimento do corpo.

O que distingue essas entidades é que eles têm mentes, o que lhes permitiria supervisionar conscientemente suas ações e intervir nelas. Os sistemas relevantes para a ação estariam subordinados a um sistema consciente de nível pessoal, que garantiria que as ações fossem feitas para atingir os objetivos conscientes do agente. Deste modo, a teoria de Steward pressupõe um dualismo que ela distancia do dualismo de substâncias, pois considera sua teoria mais próxima do dualismo de propriedades associado a P. F. Strawson (ver nota 37, 2012, p. 23).

Assim, na teoria de Steward, o que caracteriza um agente é a sua mente e a sua capacidade de intervir nas suas ações de forma consciente (deixando assim sua marca sobre ela). Seria como se a agência dependesse de um núcleo consciente centralizado que governasse as ações, responsável por desempenhar o papel do agente na produção sua ação. Essa suposição sobre agentes depende de um núcleo de consciência que desempenharia um papel direto na produção de ações; por isso se encaixa bem em uma teoria da CA, que é a teoria que Steward favorece. Como os teóricos da CA concebem agentes, e o que eles supõem que o mesmo seria, motiva o tipo de explicação de ação que eles favorecem. Por isso, é importante considerar em que se fundamenta essa concepção de agentes.

Antes de avançar é importante esclarecer que alguns autores, partidários da CA ou não, se referem à falta de participação do agente em sua ação. Não está claro exatamente o que se quer dizer com essa expressão, uma vez que é estranho pensar que um agente pode agir e não participar de sua ação. Quando um agente faz A parece contraditório dizer que a ação não foi do agente, ou que ele não participou dela. Por isso, é importante para essa discussão investigar o que alguns desses autores podem querer dizer quando usam essa expressão.

David Velleman (1992) afirma que o agente participa de todas as suas ações no sentido de que ele as empreende; no entanto, há um tipo mais específico de participação, de acordo com Velleman, que está ausente de alguns casos de ação. O autor se refere aos casos de ações que não são ações robustas. Estes são os casos em que TCA explica uma ação sem levar em conta o papel ativo do agente na produção da ação, i.e., casos em que os estados mentais causam a ação, sem deixar nada para o agente fazer na produção de ação. Velleman sugere que o papel do agente deve ser explicado por uma redução do mesmo a um dos eventos mentais que participam na produção causal da ação. 
Com certeza, uma pessoa muitas vezes executa uma ação, num sentido, sem tomar parte ativa na mesma; exemplos de tais ações serão discutidos a seguir. Mas esses exemplos não têm aquilo que distingue a ação humana do comportamento de outro animal, na nossa concepção dela, se não, na realidade (VELLEMAN, 1992, 462).

Velleman tenta explicar o papel ativo do agente na produção de sua ação como sendo algo que distingue um tipo particular de ação que chamaremos de ações robustas. Ele coloca essas ações em uma posição hierarquicamente superior às ações nas quais o agente não desempenharia esse papel ativo na sua produção.

No entanto, ainda não está claro como um agente poderia realizar uma ação sem participar ativamente na mesma. O tema da participação do agente em sua ação reaparece na teoria de Steward (2012):

\begin{abstract}
A lição, eu acho, é que não se pode esperar analisar o que é para um agente agir em termos meramente da causação de seus movimentos corporais por vários de seus estados mentais, porque sua ação tem que ser uma parte desta história, a parte que conecta esses antecedentes mentais não-ativos aos seus movimentos corporais. É o agente que tem que resolver a questão de se esses antecedentes mentais irão resultar em um movimento ou não. Essa é a forma como a psicologia popular conta a história da ação, e essa não pode ser recontada neste nível de ontologia sem a sua participação. (STEWARD, 2012, 66)
\end{abstract}

Na teoria de Steward ações não podem ser explicadas em termos de estados mentais que causam movimentos corporais, pois faltaria à ação do agente nessa explicação a chamada participação do agente. No entanto, se a teoria pretende analisar o que é para um agente agir, a ação do agente não pode ser parte da análise, uma vez que é exatamente a ação do agente que está sendo analisada. Analisar a ação do agente em termos de sua ação é pouco informativo, e essa pode ser a razão pela qual é difícil compreender o que significa um agente participar do que já é uma ação sua.

Ao se opor à explicação de ações proposta pela TCA, Hornsby (2008) argumenta que há nesse tipo de explicação o que ela chama de alienação de um tipo impensável na agência humana: "Parece impensável que a agência se manifeste de qualquer ponto de vista a partir do qual seja impossível localizar agentes" (Hornsby 2008, 178). Contudo, na objeção de Hornsby à TCA, a explicação da agência está sendo intimada a arrumar um espaço para o agente ao explicar sua manifestação de agência. No entanto, a manifestação da agência parece já envolver um agente, e devemos ter o cuidado de não explicar ações apenas apontando seu agente; afinal afirmar apenas que o agente produziu sua ação também não é muito 
informativo. Seria relevante questionar qual seria o estatuto ontológico do agente numa explicação de ações que pretenda localizar o agente na produção da sua ação.

Ainda não está claro o que significa a participação do agente em sua ação, mas há um sentido geral em que a preocupação a qual a expressão se refere diz respeito a explicações de ações em que estados mentais causam a ação, e que algo estaria faltando nesse tipo de explicação. Assim, é possível supor que isso signifique que deve haver algum tipo de papel causal na explicação das ações desempenhado por aquilo que as teorias da CA concebem como agentes. Esse poderia ser um papel de coordenação, supervisão, ou de iniciação.

Assim, a acusação de falta de participação do agente na ação será considerada como sendo uma crítica a respeito da falta de um papel causal na produção da ação pelo agente — de acordo com a concepção de agente dessas teorias. Não há na TCA um evento ao qual o agente possa ser reduzido, nem uma intervenção do agente a qual possa ser atribuído um papel específico na explicação de ações. Por outro lado, na concepção de escolha de Lowe (2008), por exemplo, essa escolha supostamente desempenharia esse tipo de papel (como será explicado a seguir).

Em vez de usar a expressão o agente não participa de sua ação—o que parece contraditório-usaremos a seguinte expressão: não há um papel que o agente desempenhe na produção da ação. Supomos que isso seria o mínimo que os críticos da TCA, como Velleman (1992), Steward (2012) e Hornsby (2008), esperariam de uma explicação de ações. Isso transfere o foco da discussão para a necessidade de clareza quanto ao que se quer dizer por agentes, dado que o papel que se espera que ele desempenhe na produção de sua ação depende do que estamos considerando um agente.

Por exemplo, se o agente é considerado como uma espécie de entidade que endossa a ação, ele teria um papel específico na produção da ação; enquanto que, se ele é pensado como um núcleo de consciência, outro papel poderia ser esperado. Isso nos traz de volta à investigação de como os agentes são concebidos. Igualmente, ajuda a tornar evidente que o modo como concebemos agentes é fundamental para a questão do DA.

A compreensão de agentes de E.J. Lowe (2008) ajuda a esclarecer a concepção de agentes da CA. Lowe acredita que a causalidade de substância ocorre com bastante frequência nas interações causais, e ele considera muitas substâncias como agentes. A maioria das pessoas, suponho, discordaria que uma pedra seja um agente, pelo menos no sentido em que estamos desenvolvendo aqui: como algo que produz ações. Objetos inanimados não são agentes neste sentido. Assim, reservaremos o termo para quando ações intencionais estiverem envolvidas. 
Deve ficar claro que o principal interesse nessa discussão são agentes humanos, o que Lowe chamaria de agentes racionais. O conceito de agentes desenvolvido aqui poderia ser aplicado a outras criaturas-por exemplo, alguns animais-mas é suficiente para o nosso problema geral limitar nossa discussão a agentes humanos. Há duas razões para essa limitação: (1) costumamos aceitar que somos agentes e que agimos. E (2) o problema do DA surge parcialmente da tentativa de acomodar a sensação fenomênica do agir que a CA defende que nós, como seres humanos, experienciamos quando agimos; pois essa experiência levaria à crença de que temos um papel na produção da ação. É possível que outros animais experimentem a mesma coisa ou algo semelhante; no entanto, não podemos testemunhar que eles o experimentem como podemos em nosso próprio caso.

De acordo com Lowe (2008), os agentes são seres psicológicos que têm uma relação sui generis com seus corpos e que se caracterizam por seu poder causal (2008, p. 122). Lowe defende a tese de que as ações reais do agente são a escolha [choice $]$ ou a vontade ${ }^{90}[$ will $]$, e que essas seriam não-causados. Assim, a vontade [will] ou escolha do agente causariam os resultados da ação, isto é, os acontecimentos no mundo. A vontade seria efetivamente a ação do agente e seria não-causada, mas causaria efeitos, ou resultados, no mundo; de modo que o agente seria capaz de intervir no mundo. No entanto, a vontade não seria um poder causal, uma vez que a vontade do agente não é determinada "pela influência causal de outros objetos" (LOWE, 2008, 155 p.). Pois Lowe supõe que a causalidade de eventos seria ou determinada ou casual.

Todas as nossas ações, incluindo as supostamente livres, são (pode-se dizer) apenas eventos, e todos os eventos são ou causalmente determinados por eventos anteriores ou então são ocorrências ao acaso (embora suas possibilidades sejam fixadas por eventos anteriores). De qualquer maneira, não há espaço para a noção de que somos os autores de nossas ações, em qualquer sentido adequado para o libertário. ${ }^{91}$ (LOWE, 2008, 160)

Lowe acredita que a concepção da causalidade do evento envolve eventos que são determinados por eventos prévios que os fazem acontecer, o que seria parte de um quadro determinista em que o agente não pode ser incluído. Ou, se a causa dos eventos não for determinada, isto significa que ela dependeria do acaso, envolvendo probabilidades que

\footnotetext{
${ }^{90}$ Vontade no sentido que Lowe (2008) confere ao termo não é um desejo ou querer, mas sim o que no inglês se diz will.

${ }^{91}$ O libertarianismo é uma posição incompatibilista (a tese de que se o determinismo for verdadeiro não há livre arbítrio) que defende que há livre arbítrio e que pelo menos às vezes seres humanos agem de forma livre.
} 
dependeriam de eventos anteriores. Ambas as possibilidades são consideradas insatisfatórias por Lowe, porque nenhuma dessas permitiria que o agente tivesse liberdade do mesmo modo que uma teoria que defende que o agente faz escolhas não-causadas.

O exercício da vontade seria uma ação não-causada, assim a concepção de agentes de Lowe é que os mesmos são substâncias psicológicas caracterizadas por aquilo que eles podem fazer; i.e., exercer a sua vontade, ou escolher. Por meio de sua escolha o agente causa eventos que são resultantes de sua escolha; sendo assim, a escolha é muito importante na teoria de Lowe, porque ela é o papel do agente na produção de ação; a sua vontade. ${ }^{92}$ A respeito da teoria que explica ações a partir das crenças e desejos do agente (TCA), Lowe afirma que "[...] essa análise deixa de fora precisamente o que é distintamente ativo quando eu levanto o meu braço e 'passivo' quando o meu braço levanta como resultado de um espasmo muscular. No primeiro caso, eu fiz algo para causar que o meu braço levantasse, mas não é assim no último caso" (LOWE, 2008, 172).

Assim, podemos concluir que a escolha é o que evita que o agente desapareça para Lowe, pois ele aceita que desejos e crenças podem causar ações, mas não ações racionais livre. Lowe diz o seguinte a respeito de um exemplo em que um agente salta para se esquivar de uma telha que está caindo de um telhado, e que provavelmente o feriria:

[...] sua ação de saltar para fora do caminho da telha qualifica como uma ação livre e racional se ele escolher saltar para fora do caminho à luz de seu desejo. Se o desejo simplesmente causá-lo a pular fora do caminho, o poder de escolha não é exercido pelo agente nessa ocasião, o seu comportamento é sem dúvida razoável, na medida em que promove os seus interesses, mas não é uma instância de ação racional (LOWE, 2008, 186).

A escolha do agente é o que faz a diferença entre uma ação racional e livre, e uma ação apenas razoável. Lowe acredita que esse é o caso porque a última não envolve o que foi chamado acima de papel que o agente desempenha na produção de ação, no sentido em que Lowe concebe agentes.

O compromisso de Lowe com a concepção de agentes como sendo substâncias psicológicas obriga-o a requerer que o agente desempenhe um papel na produção de seus movimentos. É a separação conceitual do agente-tal como ele é concebido nas teorias da CA - do corpo ao qual ele está relacionado (ou na teoria de Steward, do corpo que ele possui) que requer que o papel do agente seja adicionado à produção da ação para que essa seja

\footnotetext{
${ }^{92}$ Essa é uma referência à expressão não existe nenhum papel que o agente desempenha na produção da ação que, como foi explicado acima, alude à preocupação a respeito do DA no modelo de explicação de ações proposto pela TCA.
} 
qualificada como uma ação livre. Torna-se necessário que o agente desempenhe um papel na produção da ação para que ele não desapareça de sua ação, pois essa separação conceitual condena o agente a não ser naturalmente parte de suas ações.

Nas teorias de Lowe e Steward, o agente é visto como um tipo de ser que não é determinado por seus processos biológicos. Nesse sentido, o agente está acima desses processos, tendo em vista que ele seria capaz de se sobrepor a esses processos para produzir as ações que ele escolhe. Por isso, o problema do DA surge quando a CA discute uma explicação naturalista da produção de ações. Porque as teorias de Steward e de Lowe encontram problemas para encaixar o tipo de entidade que eles esperam que o agente sejaque está acima de seus processos biológicos—em uma explicação de ação que considere esses processos biológicos e os estados mentais realizados por eles como sendo centrais para a produção causal das ações.

Neal Judisch (2010) sugere que o problema do DA, apontado pela CA, está relacionado ao problema de uma lacuna ${ }^{93}$ que supostamente existiria entre o aspecto fenomênico da consciência e a constituição física do agente. Isso daria lugar para uma suposta lacuna entre o que a CA considera um agente (que está ligado à nossa experiência fenomênica de agir), e o que a TCA chama de agente (uma entidade cujos eventos mentais contribuem causalmente para produzir ações). Estando de acordo com a CA, Lowe formula uma teoria em que a escolha (não causada) do agente é o mais importante para explicar o papel do agente na produção de ação.

Essa concepção caracteriza agentes por sua consciência e vontade, que supostamente não seriam determinadas pelos aspectos biológicos do agente. Por exemplo, Steward afirma que "a chave deve ser ver o input do animal não como uma questão de intervenção prévia, mas de controle de cima para baixo de processos de nível inferior (como os disparos de neurônios individuais) por aqueles de nível superior (tais como a manutenção de determinados padrões de onda)" (STEWARD, 2008, 244-245). Essa causalidade de cima para baixo seria o tipo de causalidade instanciada pelo agente, segundo Steward (2012, p. 245)

Esse tipo de explicação é um equívoco. Tratar o agente, ou algo como um poder do agente, como sendo separado e independente da produção biológica da ação cria a

\footnotetext{
${ }^{93}$ Judisch (2010) defende que essa suposta lacuna seria apenas uma lacuna conceitual. Uma ilusão cognitiva contribuiria para produzir o problema do DA: "Mais especificamente, os 'conceitos fenomênicos' que nós implantamos quando observamos introspectivamente a 'sensação' de que nossos estados conscientes não são redutíveis aos conceitos em terceira pessoa de, digamos, cérebro e sistema nervoso central; nem os papéis funcionais que estes conjuntos de conceitos desempenham no nosso pensamento coincidem. A lacuna entre esses itens pode, portanto, ser classificada como irreal, uma 'ilusão cognitiva' a qual nós sucumbimos quando falhamos em apreciar o caráter especial de conceitos fenomênicos e a forma como estes conceitos funcionam dentro de nossa hierarquia cognitiva" (JUDISCH, 2010, 103).
} 
necessidade de explicar qual seria o estatuto ontológico desse agente, ou do poder do agente em questão. É justamente esse tipo de explicação que faz com que a CA espere que o agente desempenhe um papel na produção das ações de um modo que não parece possível de acordo com o que sabemos sobre ações humanas, uma vez que o agente não é uma entidade separada, uma propriedade, ou consciência, que está acima da produção biológica da ação e que conscientemente intervém nessa produção. Na verdade, estados mentais e produção de ação não estão separados dessa maneira; esses parecem estar muito ligados ao cérebro que temos (como será discutido na seção 4).

\section{Lowe: o agente como sendo uma substância distinta}

Nessa seção, será discutido a hipótese de Lowe de que o eu é uma substância diferente do corpo, ou do cérebro. A maioria das teorias da CA, como a de Steward (2012), não aceita o dualismo de substâncias; no entanto, de modo geral, elas defendem algum tipo de independência do agente, ou de sua vontade, dos processos biológicos envolvidos na produção das ações. Um argumento contra esse tipo de separação/independência será desenvolvido nessa seção.

Lowe afirma que selves não são idênticos aos seus corpos, porque o corpo não é o sujeito de suas experiências, e de acordo com ele agentes são selves. Somente a pessoa ${ }^{94}$ é o sujeito de suas experiências, e a pessoa não pode ser idêntica a seu cérebro:

(1) Eu sou o sujeito ${ }^{95}$ de todos e apenas dos meus próprios estados mentais, o que é uma verdade auto-evidente. A segunda premissa é a seguinte:

(2) Nem o meu corpo como um todo [que vamos considerar aqui como significando 'meu cérebro como um todo' ${ }^{96}$ nem qualquer parte do meu corpo poderia ser o sujeito de todos e apenas dos meus próprios estados mentais.

E sua conclusão, o que sem dúvida resulta das duas premissas, é esta:

(3) Eu não sou idêntico ao meu corpo nem a qualquer parte dele. (LOWE, 2008, 97)

\footnotetext{
${ }^{94}$ Lowe (2008) usa os termos pessoa e self como sinônimos.

${ }^{95}$ De acordo com Lowe: "Os portadores de propriedades mentais podem ser chamados, de maneira geral, de sujeitos da experiência — compreendendo 'experiência' aqui num sentido amplo, de modo a incluir não apenas experiências sensorial e perceptiva, mas também estados introspectivos e cognitivos ou, em outras palavras, consciência 'interior' e pensamentos" (LOWE, 2008, 94).

${ }^{96}$ Lowe admite que "o meu corpo como um todo" pode ser substituído por "meu cérebro como um todo", caso os fisicalistas identifiquem o self com o cérebro.
} 
Lowe acredita que precisamos de um cérebro para ter estados mentais, mas ele não acredita que precisamos do cérebro como um todo, para que tenhamos todos os nossos estados mentais. Nem meu cérebro nem qualquer parte dele seria o sujeito de minhas experiências, como por exemplo, um neurônio, que não pode ser o sujeito de todos os meus estados mentais. Apenas eu seria o sujeito dos meus estados mentais. Assim, ele conclui que $e u$ não sou idêntica ao meu cérebro.

Lowe argumenta pela sua segunda premissa ao salientar que não se pode ter estados mentais se o cérebro for destruído, no entanto, os estados mentais da pessoa não são afetados se um neurônio deixa de existir. Isso significa que a pessoa não tem que ter um cérebro como um todo em sua integridade, para que tenha todos os seus estados mentais. Portanto, o cérebro não é o sujeito das experiências da pessoa, ${ }^{97}$ porque os estados mentais continuam a existir mesmo que o cérebro perca um neurônio.

No entanto, a premissa 2 é exatamente o que Lowe está tentando argumentar. Ele já assume que há uma substância diferente—o $e u$-que é o sujeito dos estados mentais da pessoa. Mas isso é o que ele está tentando provar em primeiro lugar. Assim, seu argumento não funciona.

Assim, Lowe deve fornecer argumentos que apoiem sua premissa (2). No entanto, sua defesa é que nenhum corpo ou parte do corpo é o sujeito de todos os estados mentais da pessoa, o que já supõe que a totalidade dos estados mentais da pessoa seja uma unidade que guardaria a identidade de alguém.

Tudo o que eu estou afirmando é que não há nenhuma parte do meu cérebro que seja tal que, se qualquer parte dele - como um neurônio em particularfosse destruída, todos os meus estados mentais deixariam, assim, de existir. Isso significa que, nem o meu cérebro como um todo, nem qualquer parte distinta dele como um todo é algo com o qual eu possa ser identificado-não mais do que eu posso ser identificado com o meu corpo como um todoporque nenhuma entidade é de tal forma que todos e apenas os meus estados mentais possam depender dele da maneira que eles claramente dependem de mim. (LOWE, 2008, p. 98)

\footnotetext{
${ }^{97}$ Esse argumento é derivado de um argumento anterior de Lowe. Lowe afirma que o eu, e não o seu corpo, é o sujeito de todas as suas experiências. Tendo em vista que o corpo não seria o sujeito dessas experiências, o self não seria idêntico ao seu corpo; ele teria que ser algo diferente de seu corpo.

$\mathrm{O}$ argumento que defende que o corpo não é o sujeito das experiências da pessoa é o seguinte: (1) o corpo como um todo não é necessário para que a pessoa tenha cada um de seus estados mentais, (2), i.e., uma parte do corpo poderia estar faltando e a pessoa ainda teria seus estados mentais. (3) Uma entidade (o corpo como um todo) que poderia deixar de existir enquanto que todos os estados mentais da pessoa ainda poderiam existir não poderia ser o sujeito desses estados mentais. Porque uma parte do corpo poderia estar faltando, como um dedo, e a pessoa ainda teria todos os seus estados mentais.
} 
Mais uma vez, Lowe pressupõe o que ele está tentando argumentar: que todos os estados mentais da pessoa formariam uma unidade que teria que, em conjunto, depender de um realizador físico, se dependesse de algo. Quando Lowe afirma que nem o cérebro nem qualquer parte do mesmo é "algo com o qual eu possa ser identificado" (LOWE, 2008, p. 98), ele está supondo que os estados mentais da pessoa são algum tipo de unidade subjetiva, um $e u$. Porém, é exatamente isso o que ele está tentando argumentar; portanto, seu argumento falha por circularidade. Já está sendo pressuposto que os estados mentais são uma unidade e que os estados mentais só poderiam ser sujeitos a algo, se todos eles fossem sujeitos à mesma coisa. E para que sejam um conjunto ou uma unidade esses estados devem ter a característica de ser meus; no entanto, é possível objetar que estados mentais não são uma unidade, e que cada estado mental tem algum tipo de dependência ${ }^{98}$ de alguma parte do cérebro ou de uma rede neuronal e sua atividade. E se tal rede for danificada ou destruída o estado mental em questão deixaria de existir, a menos que fosse algo possível de ser reaprendido.

Podemos afirmar que os estados mentais dependem de atividades cerebrais, mas não há razão para crer que todos os estados mentais da pessoa, como uma unidade, dependem de uma única atividade cerebral. Ao contrário disso, os desenvolvimentos da neurociência atualmente parecem favorecer a ideia de que diferentes atividades cerebrais estão relacionadas a diferentes estados e processos mentais. Assim, não passaria de uma suposição a ideia de que os estados mentais da pessoa são uma unidade, substância, ou propriedade.

Ademais, é difícil dizer se Lowe estaria se referindo apenas aos estados mentais ocorrentes (MELE, 1992, 47) do agente, que formariam essa unidade de todos os estados mentais da pessoa, ou se estados mentais não ocorrentes ${ }^{99}$ (que não fazem parte do nosso fluxo de consciência) também fariam parte da unidade de todos os estados mentais da pessoa. Essa distinção ajuda a mostrar que atividades cerebrais têm uma conexão com estados mentais, pois a possibilidade de um estado mental ser ocorrente está na ativação de certas conexões cerebrais. Assim, certo estado mental é ocorrente quando a atividade cerebral relevante ocorre, pois estados mentais da pessoa não seriam um conjunto permanente, sempre presente.

Ao contrário do que defende Lowe, a relação que existe entre atividade cerebral e estados mentais parece acontecer de forma mais individual. Certos estados mentais parecem depender de certas atividades neuronais. Sendo assim, todos os estados mentais de uma

\footnotetext{
${ }^{98}$ Eu não me posiciono a respeito de qual seria essa a relação entre estados mentais e atividade cerebral. Quanto a essa questão eu permanecerei neutra.

${ }^{99}$ Chamados de standing na literatura em inglês.
} 
pessoa, concebidos como sendo uma unidade, i.e., o conjunto dos seus estados mentais, não poderiam estar sujeitos ao cérebro (como Lowe coloca, o cérebro não é o portador dos estados mentais da pessoa), pois os estados mentais de uma pessoa não formam uma unidade, como uma mente (que seria o que se esperaria se pensássemos que esses estados mentais são uma substância a parte, uma mente).

Mesmo que aceitássemos as premissas de Lowe, isso não daria fundamentos para sua conclusão. Muitos sistemas poderiam perder uma pequena parte, como uma célula, e ainda seriam capazes de realizar o que eles realizam. Se supusermos que cadeias neuronais têm uma relação com nossos estados mentais de, pelo menos, realizá-los, poderíamos supor que a perda de uma célula não afetaria sua capacidade de fazê-lo.

Lowe acredita que estados mentais não podem ser sujeitos ao cérebro e também ao cérebro sem uma célula. Esses não poderiam ser sujeitos a ambos. No entanto, Lowe não está levando o tempo em consideração, pois um estado mental não seria sujeito tanto a uma atividade neuronal e a essa atividade neuronal subtraída de uma célula ao mesmo tempo. $\mathrm{O}$ estado mental poderia ser em $t 1$ sujeito à atividade neuronal, $\mathrm{N}$, e em $t 2$ ele seria sujeito à atividade neuronal subtraída de uma célula, $(\mathrm{N}-\mathrm{c})$.

Também Lowe está considerando um neurônio como sendo a parte relevante do cérebro em seu argumento. Por exemplo, se uma parte tão pequena quanto uma célula for retirada de um hardware de um computador, o hardware provavelmente ainda será capaz de executar todos os aspectos de seu software. No entanto, não diríamos que o software é sujeito a uma substância diferente do hardware. Contudo, o argumento de Lowe parece forçá-lo a admitir que o software, nesse caso, seria sujeito a uma substância diferente.

O mesmo poderia ser dito para um sistema no cérebro; por exemplo, o sistema visual. Levando em consideração um sistema visual normal, que esteja funcionando bem, mas que, num dado momento, um dos neurônios do sistema é eliminado, podemos imaginar que devido à plasticidade do cérebro, isso não afetará a percepção visual da pessoa. Lowe, então, concluiria que a percepção está sujeita à pessoa, que seria uma substância diferente do sistema visual.

\section{Troca de cérebros e a neurociência}


Nessa seção será argumentado que a concepção de agente da CA, representada pela teoria de E.J. Lowe, não se encaixa com o que a neurociência tem esclarecido recentemente a respeito das atividades cerebrais e da relação dos estados mentais com as mesmas, especialmente no que se refere à plasticidade do cérebro. O ponto inicial dessa discussão será a compreensão de Lowe a respeito da relação do agente com seu cérebro, seguido pela explicação de alguns experimentos de neurociência relevantes. Em seguida, será argumentado que nossos estados mentais dependem de nosso sistema nervoso e atividades cerebrais e apenas desses, ${ }^{100}$ e que a negação desse fato contribui para forçar a CA a procurar por um papel para o agente na produção de sua ação. Essa seção também fornecerá a base para a concepção de agentes proposta no próximo capítulo, que leva em consideração essa interação de conhecimentos com a neurociência.

É evidente que a atividade cerebral é crucial para os nossos estados mentais. Os neurônios e as células gliais se conectam entre si em redes, e quando uma rede é danificada, dependendo da gravidade do dano, afetam-se a cognição da pessoa, seus estados mentais, e até mesmo sua personalidade (por vezes novas conexões são feitas como compensação, e nesse caso a pessoa pode vir a recuperar suas funções anteriormente perdidas). Como diferentes áreas do cérebro são responsáveis por diferentes funções, então danos a uma determinada área, mesmo que pequenos, podem causar perda cognitiva.

Lowe, no entanto, não parece crer que haja uma conexão forte entre uma pessoa e seu cérebro em particular.

De qualquer forma, além de qualquer outra coisa, parece claro que, mesmo concedendo que eu precise de um cérebro para ser capaz de pensar, eu não precisaria ter o cérebro que eu tenho em particular. Não encontro nada de inconcebível na ideia de que eu poderia acordar uma manhã para ser informado (verdadeiramente) que, durante a noite, eu tivesse passado por uma operação em que meu antigo cérebro orgânico tivesse de alguma forma sido substituído por um novo cérebro inorgânico. (LOWE, 2008, 21)

Então, nós não precisaríamos do cérebro específico que temos para pensar nossos pensamentos. Outro cérebro seria suficiente para pensar, mesmo um inorgânico. Essa é uma afirmação estranha. Uma evidência de que esse cenário é questionável é a plasticidade do cérebro. ${ }^{101} \mathrm{O}$ cérebro muda ao longo da vida humana, porque experiências, estimulação e

\footnotetext{
${ }^{100}$ Apesar de não tomar uma posição sobre qual o tipo de relação existente entre atividade cerebral e estados mentais, eu afirmo que existe uma relação. É suficiente para o meu propósito afirmar que existe uma relação e que estados mentais dependem da atividade do cérebro.

${ }^{101}$ A plasticidade é a capacidade do cérebro de mudar sua estrutura devido a novas experiências e demandas do ambiente. "[...], desenvolvimentos recentes em fMRI começaram a nos permitir determinar como os principais
} 
aprendizagem podem desenvolver as conexões entre os neurônios relacionados à memória, habilidades e até mesmo traços de personalidade (TREISMAN, 2009; BAARS, GAGE, 2010; FREUND et al., 2013). Desse modo, o cérebro de cada pessoa está ligado à sua história pessoal, cultura, ambiente e experiências; assim, cada cérebro é diferente do outro.

Freund et al. (2013) realizaram um experimento onde 40 camundongos (com a mesma composição genética) foram colocados em uma gaiola considerada um ambiente enriquecido. Observou-se uma divergência de atividade exploratória entre os ratos. A partir disso os experimentadores concluíram que a divergência exploratória resultou em aumento das diferenças individuais de estrutura do cérebro e de comportamento entre os animais. A forma como os animais vagaram pela gaiola, i.e., a quantidade de território que eles cobriram, mostra uma relação com as diferenças de neurogênese ${ }^{102}$ no hipocampo adulto. Assim, os fatores que surgiram durante o desenvolvimento dos animais contribuíram para as diferenças individuais na plasticidade cerebral estrutural e no comportamento. ${ }^{103}$

Freund et al. consideram a neurogênese adulta uma instanciação de plasticidade cerebral. A neurogênese estaria ligada a diferenças na experiência. Levando em consideração que os camundongos eram geneticamente idênticos, conclui-se que apenas a distinção entre experiências poderia ser responsável por essas diferenças na neurogênese. Segundo Freund et al., a função da neurogênese adulta seria a de dar forma à conectividade do hipocampo para atender às necessidades do individuo de melhoria da adaptabilidade.

"Isso está de acordo com a observação de que traços comportamentais podem ser fortemente influenciados por estímulos externos que variam entre indivíduos ou populações de indivíduos, como evidenciado por resultados divergentes de testes comportamentais em diferentes laboratórios" (FREUND et al., 2013, 758). A forma como um indivíduo se comporta parece estar fortemente relacionada às características do cérebro, que por sua vez depende de como ele é desenvolvido devido a estímulos externos. Posição intrauterina,

componentes da conectividade estrutural—os tratos de substância branca—podem também mudar como consequência da experiência. Scholz et al. (2009) mostrou que aprender a fazer malabarismos foi associado tanto a alterações na densidade da matéria cinzenta quanto nos tratos de substância branca [...]. Ou seja, como consequência da simples prática de uma habilidade motora, o cérebro muda sua estrutura em termos de densidade de matéria cinzenta e sua conectividade, em termos de tratos de substância branca" (BAARS; GAGE, 2010, 82).

${ }^{102}$ Nascimento de células cerebrais.

${ }^{103}$ Apenas camundongos geneticamente idênticos foram usados porque o experimento foi criado para investigar se diferenças de ambiente afetam a individualidade. Acredita-se que novos neurônios no hipocampo ajudariam a lidar com novidades e complexidade, o que explicaria por que os camundongos tiveram um aumento acima da média da neurogênese adulta em relação aos do experimento controle. Uma associação fraca entre a neurogênese adulta e a estimativa da distância que eles percorreram na gaiola foi observada nos camundongos. 
nutrição e interação estão entre as causas das diferenças em epigenoma. ${ }^{104}$ De acordo com Freund et al., esses fatores podem levar a diferenças iniciais em tendências de ação, o que leva a diferentes experiências, e por fim resulta numa plasticidade cerebral diferente.

A diferença entre as experiências vividas pelos camundongos resultou no ambiente não sendo o mesmo para cada um deles, o que por sua vez resultou no desenvolvimento de espaços de vida diferentes e na individualidade. Freund et al. comparam esse resultado com o desenvolvimento de diferentes traços de personalidade em seres humanos. Assim, os experimentadores concluem que o experimento ajuda a compreender como os indivíduos variam tanto em personalidade, mesmo quando eles estão no mesmo ambiente. Apenas por viver suas próprias vidas as pessoas se tornariam indivíduos bastante diferentes com diferentes traços de personalidade.

Num experimento de Miller et al. (2010), observou-se que quando pessoas diferentes realizam as mesmas tarefas elas apresentam diferentes atividades cerebrais, como se seus cérebros tomassem caminhos distintos para chegar ao mesmo resultado. Isso poderia explicar algumas discrepâncias no modo como as pessoas recuperam memórias e resolvem problemas, e talvez essa explicação possa ser expandida até mesmo à forma como as pessoas produzem ações. Pois é possível supor que, se as pessoas recuperam memórias de formas diferentes, elas poderiam também executar diferentes atividades cerebrais para produzir as mesmas tarefas como caminhar, rir, resolver problemas, etc. ${ }^{105}$

A recuperação de memórias episódicas pode envolver processos especializados que estão distribuídos em diferentes áreas do cérebro, de acordo com Miller et al. Isso dependeria da estratégia, estilo cognitivo e restrições psicológicas da pessoa. Os experimentadores também consideraram diferenças nas propriedades fisiológicas únicas como uma possível fonte de diferentes padrões de ativação entre os indivíduos. "Nós assumimos que há muitos fatores possíveis que poderiam contribuir para as diferenças individuais na atividade do cérebro, incluindo diferenças individuais no processamento cognitivo, estados ou traços psicológicos, fisiologia, anatomia, personalidade e genética” (MILLER et al., 2010, p. 09).

\footnotetext{
${ }^{104}$ Diferenças nos compostos químicos que regulam a atividade dos genes.

${ }^{105}$ Miller et al. (2010) realizaram dois scans de fMRI nos participantes do experimento durante uma tarefa de recuperação de memória episódica, uma tarefa de recuperação semântica, e uma tarefa de memória de trabalho. Os dois scans foram feitos com meses de diferença de um para o outro, o que mostrou que houve grande variação entre os padrões de atividade inter-sujeito por todo o cérebro, mas que o padrão de atividade individual manteve-se estável ao longo do tempo. A similaridade individual foi maior na realização de tarefas diferentes, do que entre indivíduos diferentes ao executarem a mesma tarefa, o que levou os pesquisadores a concluir que os indivíduos tinham estratégias diferentes para executar as tarefas. A estabilidade dos padrões de atividade em indivíduos é considerada como sendo evidência de que a variação dessas atividades em comparação com a de outros indivíduos não se deu devido a ruído nas observações.
} 
Miller et al. entretanto acreditam que algumas das diferenças no padrão de atividade podem ser explicadas por diferenças estratégicas na execução da tarefa. Diferentes estratégias envolveriam diferentes áreas do cérebro, mesmo que outros fatores também possam contribuir para essas diferenças.

A plasticidade do cérebro é evidente quando pensamos na aprendizagem e em habilidades. O famoso experimento de Maguire et al. (2000) sobre o hipocampo de motoristas de táxi em Londres é um exemplo disso. Os motoristas de táxi precisam aprender a navegar por milhares de ruas da cidade; eles apresentaram um aumento de massa cinzenta (neurônios) em seu hipocampo posterior, a área supostamente responsável por armazenar representação espacial. Isso indica que houve crescimento de uma área do cérebro responsável pela representação espacial em adultos enquanto os taxistas adquiriram novas informações de navegação, o que demonstra a capacidade de mudança plástica local no cérebro quando há exigências ambientais. ${ }^{106}$

Maguire et al. argumentam que os estudos de neuroimagem funcional associam a recuperação de informações de navegação com a ativação do hipocampo posterior, informações aprendidas anteriormente. "Nossos resultados sugerem que o 'mapa mental' da cidade é armazenada no hipocampo posterior e é acomodado por um aumento no volume de tecido" (MAGUIRE et al. 2000, 4402).

Há também uma hipótese sobre o aprendizado humano chamada de Aprendizagem Hebbiana segundo a qual conexões sinápticas mais eficientes seriam o resultado do processo de aprendizagem. ${ }^{107}$ Quando um conjunto de células dispara ao mesmo tempo, esse conjunto 'aprenderia' esse padrão reforçando as ligações entre as células. Assim, aprender e adquirir novas habilidades envolveriam o fortalecimento das conexões nas redes de neurônios. Por exemplo, uma pessoa que sabe como chutar uma bola de futebol pode ter conexões mais fortes entre alguns neurônios (pelo menos aqueles diretamente envolvidos na produção de chutes relevantes para o esporte) do que uma pessoa que não tem a mesma habilidade.

\footnotetext{
${ }^{106}$ De acordo com os pesquisadores, o hipocampo tem a função de facilitar a memória espacial na forma de navegação, além de ser uma área do cérebro que tem propensão a mudanças estruturais devido a exigências comportamentais para a memória espacial. O experimento foi concebido para investigar se haveria alterações morfológicas nessa área do cérebro causada por uma vasta experiência de navegação espacial. Os motoristas de táxi de Londres são bons sujeitos para o experimento, porque levam cerca de dois anos de treinamento de navegação apenas para adquirir sua licença.

Verificou-se que houve um aumento de matéria cinzenta no hipocampo posterior direito e esquerdo dos motoristas de táxi, em relação aos controles. O tempo como motorista de táxi também parece estar relacionado ao crescimento do hipocampo posterior direito, sugerindo que essa experiência é responsável pela mudança estrutural no hipocampo dos sujeitos. Maguire et al. acreditam que a alteração ocorre devido à exposição a estímulos ambientais, e mostra que plasticidade local na estrutura é possível em adultos saudáveis em resposta a esses estímulos.

${ }^{107}$ Ver o Capítulo 3 de Baars (2010).
} 
Se expandirmos esse cenário para a hipótese de que toda experiência e mudanças no ambiente que nos afetam (FREUND et al., 2013) conduzem ao fortalecimento de conexões específicas, essa é uma razão para acreditar que o cérebro de cada pessoa é diferente do cérebro de outra. Se as mesmas tarefas envolvem atividades cerebrais diferentes em diferentes pessoas, ao que parece, diferentes cérebros teriam diferentes padrões de atividade para executar a mesma tarefa, que variaria com cada indivíduo. As conexões cerebrais individuais parecem afetar diretamente as capacidades cognitivas das pessoas; portanto, não faz sentido pensar que estados mentais seriam algo separado e independente do cérebro. Defendemos assim a tese que estados mentais não poderiam ser separados da atividade biológica individual que os realiza.

Assim, mesmo se concedermos que a troca do cérebro de um indivíduo por outro cérebro, ou por um computador fosse possível, a plasticidade do cérebro mostra que existe uma estreita ligação entre os estados mentais e atividades cerebrais. Contudo, Lowe poderia argumentar que:

(1) Um cérebro, ou algo funcionalmente semelhante a um cérebro, é necessário para que se tenha estados mentais;

(2) Um cérebro inorgânico que fosse funcionalmente semelhante a um cérebro orgânico poderia realizar os mesmos estados mentais que o cérebro de uma pessoa realiza;

(3) Assim, o cérebro particular que uma pessoa tem não é relevante para os estados mentais que ela tem.

Mesmo que aceitemos que (1) é possível, (2) só seria possível dadas algumas suposições. Ser funcionalmente o mesmo que um cérebro orgânico provavelmente envolveria alguns requisitos físicos para o cérebro inorgânico. Não é o caso que qualquer processador inorgânico poderia realizar os estados mentais da pessoa. Haveria requisitos quanto à velocidade de processamento, requisitos de memória e de arquitetura para que ele fosse capaz de realizar estados mentais. Assim, da mesma forma, o realizador físico é relevante para os estados mentais que ele realiza.

O realizador físico em particular determinaria, pelo menos em certa medida, quais estados mentais em particular poderiam ser realizados por ele. Portanto, essas são razões para crer que os estados mentais demonstram dependência de seu realizador físico; i.e., de seu realizador físico em particular. Assim, Lowe (2008) está equivocado ao afirmar que o cérebro particular da pessoa poderia ser substituído por outro cérebro, cujas conexões supostamente 
seriam diferentes, sem que a pessoa percebesse o que aconteceu, como se o cérebro particular de cada um não fosse relevante para seus pensamentos e estados mentais. Lowe está equivocado quanto à relação dos estados mentais com as atividades cerebrais particulares que os realiza.

A tese de Lowe (2008) de que o agente seria uma substância distinta de seu corpo ou cérebro parece ir contra o que atualmente sabemos sobre o cérebro. Já a concepção de agentes de Steward (2012) é menos radical; porém, a mesma crítica ainda se aplica.

\begin{abstract}
A maioria dos animais de qualquer grau apreciável de complexidade, eu argumentarei, são possuidores de uma capacidade para um tipo de determinação de cima para baixo do que ocorrerá com respeito ao movimento de seus próprios corpos, de tal forma que sua contribuição significa algo acima da contribuição dos processos dentro deles que fazem acontecer os movimentos corporais resultantes — e são a essas criaturas que eu quero me referir quando eu digo, em (2) acima, que se há animais que movem-a-si-mesmos, o futuro está em aberto. (STEWARD, 2012, p. 17-18)
\end{abstract}

De acordo com a teoria de Steward, o agente é dono de seu corpo, e é capaz de autodeterminar suas ações de-cima-para-baixo. No entanto, este tipo de determinação supostamente opera acima dos processos fisiológicos que acontecem dentro do organismo que fazem acontecer o movimento do corpo. Com isso, Steward quer dizer que a determinação de cima para baixo é independente das operações fisiológicas/biológicas do agente. A defesa da CA envolve a rejeição de que o papel consciente do agente na produção de ação possa ser causado por seus estados mentais apenas, sem a intervenção do que a teoria chama de agente.

Assim, Steward defende um tipo de independência das capacidades do agente de suas circunstâncias biológicas, assim como Lowe (2008), e a maioria dos teóricos da CA parecem fazer. Isso faz com que essas teorias estejam sujeitas à mesma crítica: as evidências nos dão razões para crer que os estados mentais e processos cognitivos dos agentes estão fortemente relacionados com a atividade cerebral específica do agente, e apenas a ela.

Essa tentativa da CA de separar o agente dos seus processos biológicos, como se ele fosse uma substância à parte, ou como se seu papel fosse o de uma intervenção conscientenuma relação hierárquica superior em relação a seus estados mentais, ou seus realizadores físicos — engendra questões sobre o tipo de causalidade que estaria envolvida na produção de suas ações. Mas também contribui para colocar o que essas teorias chamam de agente em uma posição em que é necessário encontrar espaço para ele em meio dos seus estados mentais que contribuem causalmente para a produção de sua ação; como se os estados mentais de um 
agente não fossem essenciais para quem ele é naquele momento. Mais será dito a esse respeito no próximo capítulo.

\section{Considerações finais}

O presente capítulo lança os fundamentos para o próximo, no qual será defendido que a plasticidade do cérebro e as diferenças nas conexões neuronais de cada agente dão razões para acreditar que a produção das ações de cada agente é característica desse agente. Isso é relevante para o problema do DA porque mostra que a produção causal de uma ação pelos estados mentais (ou por seus realizadores físicos) do agente é característica dele, e resulta de suas experiências e desenvolvimento.

Nesse sentido, não se pode dizer que o agente não desempenha um papel na produção de suas ações. A não ser que o requisito para que alguém seja um agente seja colocado tão alto que apenas uma entidade compatível com uma concepção dualista de agentes poderia ser considerada um agente. 


\section{Capítulo V - Uma Nova Concepção de Agentes}

\section{Introdução}

Uma concepção diferente de agentes com base na plasticidade do cérebro humano (discutida no capítulo anterior) será apresentada neste capítulo. Compreender o que são agentes depende do que são ações, e não o contrário. É importante também levar em consideração nessa discussão a experiência fenomênica do agir; porém, apesar de essa ser considerada uma experiência que acompanha a ação, será argumentado que ela não pode ser considerada uma evidência do controle consciente do agente sobre sua ação. Assim, no contexto conceitual apresentado, não surge o problema do Desaparecimento do Agente (DA), porque o problema surge a partir de certa concepção equivocada de agentes.

\section{O que é um agente?}

Pressupostos sobre o que seria um agente e quais seriam as nossas capacidades como agentes têm uma grande influência sobre as teorias da Causalidade do Agente (CA). Essas teorias tentam encaixar uma explicação de ação com certa concepção de agentes. Nessa seção, uma concepção geral do que são agentes será apresentada; no entanto, a mesma será guiada pelo que são ações, e não o contrário. Isso leva a uma discussão sobre qual explicação de ação pode acomodar o que sabemos sobre a plasticidade do cérebro e o que essa plasticidade esclarece sobre a produção causal de ações do agente.

Uma condição necessária para que algo seja um agente é a capacidade de agir. Alfred Mele ressalta que "ser um agente humano é ser um ser humano que age" (MELE, 2003, p. 216). Normalmente aceitaríamos que, para que algo seja um agente o mesmo deve pelo menos ser capaz de agir. Nesse sentido, essa é uma condição menos exigente do que aquela proposta pela teoria da CA: um agente seria alguém que tivesse a capacidade de agir, e às vezes a exercesse. No entanto, não há na filosofia da ação um consenso sobre o que é uma ação, ou a respeito de como o agente produz sua ação, como vimos no Capítulo I. Teóricos da CA 
(LOWE, 2008; O’CONNOR, 2000) poderiam argumentar que ações causadas por estados ou eventos mentais não envolvem um papel para o agente na produção de ação, de modo que não poderiam ser consideradas explicação aceitável para as ações humanas. Portanto, esses teóricos defendem a ideia de que um tipo de causalidade diferente, a causalidade do agente, seria necessária para explicar ações de forma apropriada.

Assim, o conceito de agente depende da forma como ações são explicadas, porque é a explicação da ação que define como o agente age, e isso é o que caracteriza um agente. Será argumentado nesse capítulo que uma explicação de ação de acordo com a Teoria Causal da Ação (TCA) se encaixa melhor com o que sabemos da plasticidade do cérebro do que aquela da CA.

Lowe (2008) afirma que, se crenças e desejos causam uma ação, essa não poderia ser considerada uma ação racional e livre; embora ele aceite que a mesma pode ser considerada uma ação. É como se essa fosse uma espécie hierarquicamente inferior de ação. Assim, de acordo com Lowe, um agente que se esquiva de uma telha que cai do telhado em sua direção não age racionalmente se ele o faz porque acredita que a telha cairia sobre ele e porque ele deseja não ser ferido. Pois, o agente não desempenharia um papel ativo em tal ação; apenas estados mentais causariam sua ação, de modo que não haveria um papel para o agente na produção da ação.

Timothy O'Connor (2002) defende uma ideia parecida à de Lowe nesse sentido. O'Connor afirma que ele não é capaz de conceber que um agente pudesse ter controle sobre sua ação, se ele não está ciente de suas motivações para agir. Nesse caso, a consciência do agente de suas motivações para agir e o controle que ele teria sobre sua ação garantiria que a ação fosse livre. Nessa teoria, o controle é o que garante que o agente tenha um papel ativo na produção de sua ação; portanto, o controle garantiria que a ação fosse livre. Se o agente não tiver controle sobre sua ação, essa não poderia ser considerada uma ação livre; todavia, O'Connor não afirma que a mesma não poderia ser uma ação.

Podemos supor que aquilo que Lowe e O'Connor chamam de ação não-livre também não seria considerada uma ação robusta nos termos de David Velleman (1992). No exemplo de Velleman, o agente faz comentários hostis para um amigo sem ter consciência de seu próprio desejo de romper a amizade. Isso não leva Velleman a sugerir que os comentários não tenham sido ações; entretanto, ele não os considera como ações robustas.

Nesse contexto, Judisch (2010) argumenta que, atualmente, a explicação de ações por meio do par crença-desejo (ou a explicação da causalidade-de-eventos) parece ser um consenso a respeito da produção de ações. Teóricos da CA, como Lowe (2008) e O'Connor 
(2002), já não defendem que as ações produzidas dessa forma não possam ser consideradas ações - como algumas versões anteriores da teoria defendia ${ }^{108}$ - as teorias da CA recentes argumentam apenas que as ações assim produzidas não poderiam ser ações livres.

De modo geral, entretanto, as teorias da CA ainda mantêm que explicações em que ações são causadas por eventos mentais anteriores mantêm o agente fora da explicação da ação, porque essas explicações não envolvem um papel para o agente na produção da ação. A ideia é que, se as ações são causadas por eventos mentais que, por sua vez, são causados por eventos mentais anteriores, então, o agente não teria um papel ativo na produção da ação; ele seria apenas o cenário no qual essa causação aconteceria (NAGEL, 1986; VELLEMAN, 1992). Assim, o agente não produziria sua ação, apenas partes do agente a produziriam, o que tornaria a ação um mero acontecimento no mundo, e lhe tomaria aquilo que a torna uma ação livre (na abordagem de Lowe e O'Connor, por exemplo). Na seção seguinte será argumentado que essa noção está equivocada.

\section{Agentes, estados mentais e seus realizadores físicos}

É difícil conceber que o agente não teria um papel em uma ação causada por seus estados mentais, como motivações e intenções. Como foi explicado no capítulo anterior, os seres humanos (e alguns outros animais) têm cérebros que apresentam plasticidade. Foi argumentado que a plasticidade do cérebro nos dá razões para crer que nossos estados mentais e capacidades cognitivas são dependentes do cérebro que cada um tem; i.e., das conexões cerebrais específicas de cada um. ${ }^{109}$ Assim, eles seriam particulares ao agente. E essa é uma razão para crer que nossos estados mentais têm uma estreita relação com nosso cérebro em particular. $^{110}$

O aspecto relevante dessas considerações é que: há uma relação entre os nossos estados mentais e a atividade cerebral que os realiza. Essa é uma evidência de que nossos estados mentais não estariam relacionados à outra substância, nem que seriam determinados

\footnotetext{
${ }^{108}$ Judisch cita Chisholm (1966) como exemplo.

${ }^{109}$ Mesmo que eles sejam realizados por um cérebro inorgânico funcionalmente semelhante, haveria requisitos físicos para que o cérebro inorgânico realizasse os estados mentais de uma pessoa, vide o capítulo anterior. Portanto, esse realizador físico em particular é relevante para os estados mentais que ele realiza, pois depende dele quais estados mentais em particular serão realizados.

${ }^{110}$ Contudo, eu me mantenho neutra quanto ao tipo de relação que essa seria. Será defendido apenas que os estados mentais dependem de atividades cerebrais.
} 
por uma consciência centralizada de nível pessoal (como sugere STEWARD, 2012). A evidência, na verdade, sugere que estados mentais estão relacionados a atividades cerebrais.

Dada essa característica do cérebro humano, quando um agente age os estados mentais que causam a ação estão relacionados a algumas atividades cerebrais do agente. E essas atividades são particulares ao agente; pelo menos na medida em que conexões neuronais particulares ao agente estão sendo ativadas, como é sugerido pelas descobertas a respeito da plasticidade do cérebro. Eu não considerarei que seja uma ideia polêmica a tese de que estados mentais contribuem causalmente para a produção de ações, uma vez que teorias recentes da CA também a aceitam (O’CONNOR, 2000; LOWE, 2008). Essas teorias exigem que a explicação da ação envolva a causalidade do agente apenas para explicar ações livres, ${ }^{111}$ ou seja, aquelas em que o agente desempenharia um papel ativo. Contudo, nesse capítulo será argumentado que esse requisito está equivocado.

Como foi exposto no último capítulo, o cérebro de cada agente exibe um padrão singular de atividade ao executar tarefas de recuperação de memória; a diferença na atividade fica clara quando são comparadas as imagens de dois cérebros distintos executando a mesma tarefa. Assim, é possível sugerir analogamente que agentes diferentes podem ter diferentes estratégias e atividade cerebral quando executam outras tarefas, não apenas a recuperação de memórias. Ademais, dado o desenvolvimento do cérebro de cada agente, quando um agente come um pêssego porque ele sentiu fome e tinha a intenção de comer um lanche saudável, os eventos cerebrais relacionadas à sua motivação e intenção-assim como a atividade que desencadeia os movimentos musculares relevantes-seriam exclusivos do agente.

Levando em consideração apenas a capacidade de agir de Natan e seu nível de habilidade para lançar uma bola, já é possível imaginar que o padrão de atividade relevante para o lançamento será diferente do de alguém que seja menos habilidoso. Assim, não é o caso que uma ação de Natan seja apenas um acontecimento no fluxo de eventos, no qual o agente não desempenharia nenhum papel na produção, como é colocado pelo problema do DA. Também não é o caso que partes de Nathan causam sua ação sem qualquer papel ativo do agente na sua produção, porque esses estados mentais resultam das experiências e do desenvolvimento de Natan. Isso fica claro levando-se em conta a conexão entre os estados mentais que causalmente produzem a ação e sua atividade cerebral particular.

\footnotetext{
111 “O ponto fundamental aqui é que causas fazem acontecer seus efeitos com total indiferença para com a questão de se há ou não considerações objetivas em favor desses efeitos produzidos. Mas agentes livres e racionais não podem agir livremente e de forma racional sendo indiferentes a tais considerações e por isso não podem, ao agir livremente e de forma racional, ser causados a agir por suas crenças e desejos" (LOWE, $2008, \mathrm{p}$. 200).
} 
A ação de Natan é, portanto, essencialmente uma ação dele, porque sua produção envolve aspectos particulares de Natan ligados à sua história e experiências. Na versão da ação de jogar a bola produzida por Nathan, essa produção em particular remonta ao agente, como ele era constituído no momento do lançamento. Nesse sentido, a ação e sua produção causal são características de Natan.

A produção dessa ação depende da composição genética de Natan, mas também de toda a sua história de desenvolvimento como indivíduo até o momento, pois essas moldam suas conexões cerebrais. As experiências de Natan levaram parcialmente à configuração do seu cérebro e ao fortalecimento das conexões entre seus neurônios. Podemos supor que o seu desenvolvimento neuronal e conexões poderiam ter variado tanto quanto sua cultura, meio ambiente e experiências poderiam ter variado. As possibilidades eram numerosas e eram contingentes quais habilidades Natan iria desenvolver, e quais conexões neuronais ele iria fortalecer.

Uma vez que esse desenvolvimento está ocorrendo, se considerarmos que Natan lança a bola no momento $t 1$, ele tendo agido como agiu, e sendo a ação produzida como foi (seus estados mentais desempenhando o papel causal que eles desempenham), pouca variação seria possível na produção dessa ação de Natan, tendo em vista que se trata de uma ação produzida por Natan. A ação token realizada no momento por Natan só poderia ter sido produzida pela configuração neuronal em particular que é característica de Natan. ${ }^{112}$ A sua produção causal, que depende dessa configuração neuronal, poderia ter apenas uma pequena variação para permitir que essa ação token permanecesse a ação que foi.

Nesse sentido, a ação de Natan de lançar a bola em $t 1$ é caracteristicamente uma ação de Natan por causa de sua produção causal característica. Outro agente poderia também lançar uma bola em $t 1$; porém, de acordo com a teoria sendo proposta, a produção causal de sua ação teria que ser diferente de produção causal do arremesso de Natan. Pois a atividade cerebral relevante ocorreria de acordo com uma configuração neuronal diferente. ${ }^{113}$

Isso faz com que a produção da ação de Natan em $t 1$ seja ligeiramente distinta da de outro agente que empreendesse a mesma ação. E esse é o caso para todos os agentes; a

\footnotetext{
${ }^{112}$ Num cenário de ficção científica, um cérebro inorgânico funcionalmente semelhante que substituísse o cérebro original de Natan poderia ter produzido a ação de Natan. Contudo, o cérebro inorgânico teria que preencher alguns requisitos para que ele pudesse realizar os estados mentais de Natan, incluindo os que são relevantes para a sua ação. No entanto, essa é uma possibilidade tão distante que é difícil imaginar como seria um cérebro inorgânico, e como ele realizaria os estados mentais causalmente relevantes para a ação. Por isso, não nos preocuparemos com essa possibilidade aqui.

${ }^{113}$ Como apenas cérebros humanos fazem parte de nossas considerações, devemos lembrar que a distinção entre as conexões se mantém dentro dos limites da anatomia do cérebro humano.
} 
produção de suas ações é, assim, característica ao agente. Desse modo, uma vez que o agente empreende uma ação - por exemplo, lançar uma bola — sua produção causal a caracteriza como sendo uma ação de Natan. Outros agentes, naturalmente, também podem empreender a ação de lançar uma bola, mas a produção da ação de cada um será característica de cada agente. Nesse sentido, e apenas neste sentido, podemos dizer que a ação token de Natan só poderia ter sido empreendida por Natan, pois a produção da ação é particular a cada agente.

\section{Eventos frágeis}

Contudo, um problema surge a partir dessa teoria. Um evento é modalmente frágil quando uma pequena diferença na sua causa destruiria o evento ou o transformaria num evento diferente. Num evento frágil, uma mudança na causa do evento faria com que o evento tivesse sido um pouco diferente, ou tivesse sido atrasado, e essas distinções fariam dele um evento diferente (LEWIS, 2004, p. 86). No entanto, não sabemos quanta diferença ou atraso em um evento o substituiriam por um evento totalmente novo $(2004,86)$.

A solução de David Lewis (2004) para esse problema concede que existam alterações de eventos. Uma alteração no evento E seria um evento E1, digamos, que ocorreria num mundo possível próximo ao nosso, e poderia ser considerado como sendo uma versão frágil de E. Ou E1 poderia ser um evento diferente, frágil, alternativo e semelhante a E. O evento E1 que ocorre em outro mundo possível pode ser considerado uma alteração frágil de E que ocorre ao invés de todas as outras possíveis alterações de E em outros mundos possíveis. Isso nos dá duas opções: se aceitarmos que uma possível alteração E1 é um evento diferente de E, suas alterações que correm em outros mundos possíveis (E1 a En) seriam consideradas numericamente diferentes de E. Por outro lado, se aceitarmos que uma possível alteração E1, não é um evento diferente de $\mathrm{E}$, suas alterações que ocorrem em outros mundos possíveis (E1 a En) seriam consideradas versões do mesmo evento E. Também é possível que haja graus de alterações. Então, se a causa C (ou sua alteração C1) não tivesse ocorrido, a alteração E1 não teria ocorrido. Assim, de acordo com Lewis, a alteração E1 é frágil por definição.

Assim, Lewis afirma que, se C, ou qualquer ligeira alteração de $C$ (dentre uma gama de C1 a Cn) não ocorre, então E, ou qualquer ligeira alteração de E (dentre uma gama de E1 a En) não ocorre. E a alteração de uma causa, $C$, até o ponto em que essa passa a ser uma 
grande alteração de C—por exemplo, em vez de Natan lançar a bola, Sara o faz—significaria alguma alteração no efeito, supostamente uma alteração significativa. Ainda assim, se não quisermos nos comprometer com a tese de que eventos são frágeis, não é necessário estabelecer se uma alteração na causa transformaria um evento em outro diferente. É suficiente reconhecer que se trata de uma alteração significativa na causa do efeito, mesmo se considerarmos que a alteração originaria apenas uma versão diferente do mesmo efeito. Essa é a posição que eu tomarei aqui, me manterei neutra quanto à questão da fragilidade dos eventos, deixando para que o leitor aplique a teoria de sua preferência.

Se o efeito não ocorre mais tarde, ou de uma forma diferente; então, é possível fazer a análise contrafactual, i.e., é possível perceber que o efeito E1 foi causado pela causa $\mathrm{C} 1$. Se o efeito tivesse acontecido mais tarde ou de forma diferente, então, ele teria sido causado por uma causa diferente que poderia ser tanto uma grande alteração de $\mathrm{C} 1$ como uma ligeira alteração. Isso provavelmente dependeria do quão distante o efeito possível seria do efeito atualizado. A diferença entre um possível efeito e o efeito atualizado pode ajudar a determinar se o primeiro (se fosse atualizado) seria um novo evento ou se seria uma versão do mesmo evento. De qualquer modo, para os propósitos da teoria proposta aqui, podemos permanecer neutros sobre a questão de saber se os eventos são frágeis ou não.

Uma versão diferente do efeito teria sido causada por uma alteração da causa (ou por uma causa diferente), e isso é tudo o que a presente teoria precisa afirmar: que as diferenças no tempo e na forma da causação constituem, no mínimo, uma alteração da causa do evento. Isso nos permite dizer que uma alteração significativa da causa de uma ação significaria uma alteração significativa do seu efeito. Assim, a produção da ação de Natan produz um lançamento de bola, enquanto que a produção da ação de Sara produz um lançamento de bola diferente. A produção de uma ação significa que o evento resulta da atividade cerebral de um agente, mas se houvesse uma alteração grande o suficiente no evento essa seria resultante da atividade cerebral de outro agente, como no caso do lançamento de bola de Natan e de Sara.

Essa concepção de agentes e de como as ações são causalmente produzidas pode não impressionar aos teóricos da CA, pois alguns acreditam que o self tem uma relação de propriedade com seu corpo, i.e., de ser o dono do corpo (STEWARD, 2012); ou acreditam que o self é uma substância separada de seu corpo (LOWE, 2008). No entanto, foi argumentado acima que há razões para crer que o agente não tem uma relação de dono com seu corpo, nem o agente é caracterizado por um tipo de influência consciente na ação. ${ }^{114} \mathrm{Na}$

\footnotetext{
${ }^{114}$ Vide os argumentos para essa afirmação no capítulo anterior.
} 
verdade, nossos estados mentais parecem ter uma relação íntima com a nossa atividade cerebral.

O que consideramos ações deveria orientar a nossa concepção de agentes, tendo em vista que agentes são caracterizados pela sua capacidade de agir. Ações, entretanto, não são apenas movimentos musculares produzidos pelo sistema nervoso; portanto, é importante acrescentar uma explicação de ações a essa proposta que possa tornar claro o que se quer dizer com a capacidade de agir, i.e., como o agente produz sua ação. Porém, por causa dos pressupostos que a CA tem acerca do agente (discutidos anteriormente), essa teoria não pode explicar ações independentemente de sua concepção de agentes. Ele fornece uma explicação de ações que precisa envolver certa concepção de agentes, que requer que esse seja uma substância separada de seus processos biológicos, ou uma influência consciente na produção da ação.

Por essa razão, a TCA é uma explicação melhor para ações, uma vez que a teoria pode acomodar os resultados empíricos que motivam a concepção de agentes proposta aqui. Nossa condição de seres humanos deveria ser o único pressuposto para a nossa concepção sobre o que são agentes humanos. Assim, agentes são criaturas que têm capacidade de agir e, de acordo com a TCA, ações intencionais são explicadas por estados mentais do agente que contribuem causalmente para a produção da ação da maneira certa. ${ }^{115}$

\section{Explicação de ações}

Um problema surge se aceitarmos que ações são movimentos causalmente produzidos pela atividade cerebral relevante, pois nem todos os movimentos produzidos dessa maneira seriam normalmente considerados ações intencionais. Portanto, nessa seção será argumentado que os agentes são caracterizados pela sua capacidade de produzir causalmente ações intencionais, o que tem como base os estados mentais do agente-ou seus realizadores físicos - contribuírem causalmente para a produção de suas ações. Até mesmo alguns teóricos da CA aceitam essa explicação de ações, pelo menos até certo ponto. Igualmente, será argumentado que não existe um papel para o agente na produção de sua ação que esteja além de seus estados mentais contribuírem causalmente para a produção da ação.

\footnotetext{
${ }^{115}$ Essa é uma explicação aproximada do que a TCA geralmente considera como sendo uma ação, podendo haver algumas variações.
} 
O teórico da CA poderia argumentar que, normalmente, não consideramos qualquer movimento como sendo uma ação. Dado que a maior parte dos movimentos corporais seria, normalmente, produzida pelo sistema nervoso central, se esses movimentos fossem considerados ações intencionais simplesmente por serem produzidos pela nossa atividade cerebral, então reflexos musculares e espasmos musculares teriam que ser considerados ações intencionais também, de acordo com a concepção apresentada na seção anterior.

No entanto, se aceitamos que ações intencionais são causalmente produzidas (da maneira correta) por estados mentais do agente, ou seus realizadores físicos, como sugere a TCA (MELE, 2003), e se é isso o que queremos dizer quando dizemos que agentes tem capacidade de agir, então um espasmo muscular não seria considerado uma ação. Pois, um espasmo muscular não é causado da maneira certa pelos estados mentais do agente (como desejos e intenções); por isso, um espasmo não seria considerado uma ação intencional de acordo com a tese que está sendo proposta.

Até mesmo alguns teóricos da CA aceitam que ações podem ser causadas por estados mentais do agente; no entanto, a CA defende que essas não seriam ações livres do agente, porque supostamente não envolvem um papel para o agente na produção dessas ações. Nesse contexto, concordo com a tese de Judisch (2010) de que alguns teóricos da CA exigem apenas que a causalidade do agente faça parte da produção de ações livres, e não de todas as ações. As teorias de Lowe (2008) e de O'Connor (2002) são exemplos disso.

Portanto, para que alguém seja considerado um agente humano, no sentido que nos interessa aqui, ele deve ser capaz de agir, e os requisitos para isso não precisam ser tão exigentes quanto o que a CA espera para que uma ação seja considerada livre. Uma ação apenas precisaria ser o que a TCA chama de ação intencional, e se alguns teóricos da CA aceitam essa explicação de ações, como foi mostrado acima, então, esse não deve ser considerado um ponto polêmico.

Assim, nossa teoria discorda da afirmação da CA de que o agente não desempenha nenhum papel nas ações causadas por seus estados mentais. Considerar as ações causadas por estes estados mentais como sendo ações produzidas pelo agente é totalmente compatível com o que sabemos sobre a nossa atividade cerebral (da qual os estados mentais dependem), tendo em vista que sua produção é particular e característica do agente. A necessidade de uma substância especial, ou propriedade que interviria nos processos biológicos do agente é, então, descartada. Um agente em particular não deve ser visto como algo além de um ser em 
particular que tem capacidade de agir garantida pelos seus processos biológicos. Uma vez aceito isso realmente não há espaço para qualquer outro poder causal. ${ }^{116}$

\title{
6. Fenomenologia da ação
}

Uma preocupação a respeito da TCA é que ela não levaria em conta a experiência fenomênica do agente ao causar sua ação.

\begin{abstract}
Experimentar a si mesmo sendo ativo ao fazer algo não pode ser equiparado a experimentar alguma conexão causal entre a própria intenção de fazer alguma coisa e a mudança relevante. Quando uma pessoa tem a experiência de levantar seu braço ativamente ela não tem, assim, uma experiência com o seguinte conteúdo: tenho a intenção de levantar o braço e a intenção causa meu braço a levantar. Podemos estar cientes de executar ativamente um movimento sem estar cientes de qualquer intenção de se mover. Ademais, certamente não é o caso que nós experimentamos nossa própria intenção causando um movimento sempre que temos a experiência de nós mesmos sendo ativos em uma ação corporal. Eu duvido que alguma vez tenhamos a experiência de nossas intenções ou outros eventos ou processos mentais (como crenças ou desejos) como sendo a causa da mudança corporal relevante. (NIDA-RÜMELIN, 2007, p. 259)
\end{abstract}

Essa experiência é vista não apenas como evidência do papel do agente na produção de ação, mas também como seu correlato fenomênico. Isso sugere que existe alguma forma de atividade direta do agente na produção das ações, quando na verdade essa experiência poderia corresponder a qualquer um dos eventos cerebrais que participam da produção causal da ação. Na realidade, não há um evento que equivalha ao papel do agente no sentido que os teóricos da CA esperam, o que se mostrou relevante para o problema do DA.

Nessa seção será discutida como a experiência fenomênica se encaixa com o que foi dito acima sobre os agentes e suas ações. Além disso, o experimento de José Delgado (1969) pode ajudar a esclarecer a relevância da experiência fenomênica para a produção de ações, como será explicado nessa seção. Finalmente, será argumentado que, frente à concepção de agentes proposta, o problema do DA perde o seu significado.

\footnotetext{
116 Adicionar o poder causal do agente à produção de ação traria o problema da sobredeterminação [overdetermination], ou seja, o problema de haver mais do que uma causa fazendo o trabalho causal quando apenas uma é suficiente para causar o evento em questão.
} 
Uma possível objeção seria que a concepção de agentes proposta aqui deixa de fora o aspecto fenomênico do agir, pois não leva em conta a sensação fenomênica que agentes humanos têm ao desempenhar um papel ativo na produção de suas ações. Quando agimos, temos a experiência de que estamos causando, ou produzindo a ação, bem como a experiência da ação em si. Nesse último caso, quando os nossos músculos estão se movendo temos a sensação de que estamos movendo nossos músculos.

No entanto, deve ser feita uma distinção entre a experiência de produzir a ação, e da experiência de agir, i.e., dos músculos executando a ação. Quando um agente tem a experiência fenomênica de produzir sua ação, essa não é a mesma que a experiência do movimento muscular. E quando teóricos da CA (LOWE, 2008) fazem objeção à TCA porque, segundo eles, o agente não desempenharia um papel na produção de ação, essa objeção parece direcionada à acusação de que a TCA não é capaz de explicar o primeiro tipo de experiência, a experiência de produzir a ação.

Em primeiro lugar e acima de tudo (como eu sugeri no início), a teoria da agência é atraente porque captura a forma como experienciamos nossa própria atividade. Não me parece (pelo menos ordinariamente) que sou causado a agir pelas razões que favorecem fazê-lo; parece ser o caso, pelo contrário, que eu produzo a minha decisão, tendo em conta essas razões, e poderia ter, em um sentido incondicional, decidido de forma diferente. (O'CONNOR, 1995, p. 197)

O'Connor usa o termo decisão como sendo o "evento central da causação do agente" (O'Connor 2002, 86), que é a atividade causal auto-determinada de iniciar a ação. Assim, O'Connor está se referindo à experiência que agentes têm de produzir ativamente suas ações. E isso não é o mesmo que a experiência de mover seus músculos, como Nida-Rümelin (2007) deixa claro: "outra proposta equivocada (talvez demasiado absurda para valer a pena mencionar) seria interpretar a experiência de ser ativo na própria ação como sendo a consciência fenomênica de sua própria contração muscular" (NIDA-RÜEMELIN, 2007, p. 259).

Uma possibilidade para explicar essa experiência seria que ela estivesse relacionada à consciência dos estados mentais envolvidos na produção da ação. Assim, quando o agente tivesse consciência de sua intenção, ele provavelmente teria a experiência de produzir causalmente a ação. No caso das ações automáticas, ele não teria essa experiência; ele apenas teria a experiência de mover seus músculos. 
Claro, pode-se estar consciente de uma intenção que acabe não sendo executada por qualquer razão, ou de uma intenção distal que não é executada imediatamente. Em ambos os casos, não podemos dizer que o agente teve a experiência de causalmente produzir sua ação, porque os mecanismos responsáveis pelo movimento dos músculos não foram acionados. A consciência do acionamento desses mecanismos, ou a consciência da intenção imediata de acordo com a qual o agente age, pode ser importante para a experiência fenomênica do agir. Esse tipo de experiência consciente não será explicitado aqui. No entanto, não vejo por que isso seria um problema para a TCA mais do que para as teorias da CA, uma vez que as últimas também precisam explicar como essa experiência é produzida.

José Maria Delgado (1969) relata um caso interessante em seus experimentos com pacientes. Quando o neurocientista estimulava o cérebro de uma paciente, de forma que produzia um movimento, a paciente dizia que ela tinha movido a cabeça para olhar para a porta.

Por exemplo, em um dos nossos pacientes, a estimulação elétrica da parte rostral da cápsula interna produziu que a cabeça virasse e o deslocamento lento do corpo para qualquer um dos lados numa sequência bem orientada e aparentemente normal, como se a paciente estivesse procurando alguma coisa (DELGADO, 1969, p. 115).

O experimentador repetiu o estímulo seis vezes, em dias diferentes, e obteve o mesmo resultado. Delgado afirma que a paciente considerava seu movimento espontâneo, e sempre oferecia uma explicação para o mesmo.

Os experimentos de Delgado (1969) contribuem para a tese que está sendo proposta aqui. Parece que a paciente teve a experiência de produzir a ação correspondente à produção do movimento pelo experimentador por meio da estimulação de uma área de seu cérebro. Assim, essa é uma evidência de que houve uma estimulação cerebral que foi, provavelmente, responsável pela produção causal da experiência de ter agido, a paciente não considerava seu movimento estranho, ou como sendo causado pelo experimentador, mesmo a ação tendo sido produzida por um estímulo externo, direto no cérebro. Delgado afirma que a paciente a via como tendo sido espontânea, e sempre oferecia uma explicação para ter agido.

Assim, a experiência de produzir a ação não deve ser considerada como sendo uma evidência (ou prova) de que o agente desempenha um papel direto na produção de sua ação. Igualmente, essa experiência não pode ser considerada como sendo o fundamento sobre o qual as teorias da ação devem desenvolver suas explicações para a produção da ação. A experiência fenomênica da produção da ação, provavelmente, tem uma função diferente da 
que espera a CA: de ser o papel do agente ou a experiência desse papel na produção da ação. ${ }^{117}$ Pode ser que essa experiência consciente ajude a recrutar sistemas desencadeadores do movimento muscular, atenção, ou atividades similares.

O problema do DA repousa sobre uma concepção de agentes que os considera uma central unificada do controle das ações, segundo a qual todos os processos envolvendo o agente devem passar por essa central, ou estar sob a sua supervisão. Em algumas versões da CA (LOWE, 2008; CHISHOLM, 1964), cada ação (ou cada ação considerada livre) deve ser causada diretamente por essa central. A tese proposta aqui, a Hipótese da Difusão, não envolve um sistema unificado; a experiência consciente é produzida por um sistema distribuído.

$\mathrm{Na}$ concepção favorecida aqui o agente é um ser humano que tem a capacidade de agir. Assim, é essa capacidade que caracteriza os agentes, não um tipo de substância ou propriedade que o agente deve ser. Essa é a capacidade dos estados mentais do agente-e.g., desejos e intenções - de produzir causalmente ações intencionais. Nesse sentido, não há um controle centralizado das ações.

Neste contexto, o problema do DA perde seu significado. A falta de uma explicação para a experiência de agir não significa que esteja faltando algum tipo de papel especial do agente na produção de sua ação, pois é possível explicar essa experiência de outras maneiras que não envolvam um papel causal especial do agente na produção da ação; por exemplo, a experiência em questão poderia envolver o recrutamento de mecanismos responsáveis pelo movimento dos músculos. Como foi explicado acima, as ações são produzidos de tal forma que a sua produção é característica do agente, e apenas o agente poderia ter realizado os estados mentais responsáveis pela produção causal da ação. Essa explicação não tentar reduzir o agente a um controlador central, ou a um estado mental ou evento, porque o agente não é algo separado de seus estados mentais para que o mesmo possa ser reduzido. O que está sendo proposto é justamente que essa concepção de agentes é equivocada.

$\mathrm{Na}$ verdade, o papel desempenhado pelos estados mentais do agente (ou seus realizadores físicos) é essencialmente a produção da ação pelo agente. A singularidade da realização dos estados mentais mostra que a produção causal da ação depende essencialmente das contingências que fisicamente compõem o agente. A sua capacidade de produzir ações repousa nisso, enquanto que a sua experiência de produzir a ação poderia ser a amplificação da atividade cerebral que realiza os estados mentais envolvidos na produção causal da ação,

\footnotetext{
${ }^{117}$ No capítulo 3 , foi sugerido que a consciência das intenções poderia servir uma função informativa. Poderia ser a difusão do conteúdo da intenção, a fim de recrutar sistemas necessários para executar essa intenção.
} 
como foi discutido no Capítulo III. Igualmente poderia haver uma explicação para a experiência relacionada aos mecanismos que desencadeiam o movimento muscular. De qualquer maneira, o agente não pode ser considerado passivo nesses processos, porque essas atividades resultam da genética, das experiências e da história do agente, que constituem o seu desenvolvimento que o levou a ser o agente que ele é. Essa é a concepção de agentes proposta aqui e tem fundamentos mais sólidos do que a concepção que considera o agente como sendo uma entidade consciente que deve influenciar diretamente a produção da ação.

Com isso, não estou afirmando que o problema da experiência consciente da ação não seja importante para a explicação da produção causal da ação; contudo, defendo que a experiência fenomênica não parece fornecer uma base sólida para que seja considerada como sendo o fundamento das explicações de ações humanas. Levando isso em consideração, assim como a concepção de agentes proposta, o problema do DA perde seu significado. É preciso reconhecer que o agente não desaparece na TCA; agentes apenas não são o que a CA espera que eles sejam.

\section{Considerações finais}

A concepção de agentes da CA orienta a explicação de ações proposta pela teoria. Mas de acordo com o que foi argumentado acima, essa é uma concepção equivocada; o que as versões da $\mathrm{CA}$ apresentadas esperam que agentes humanos sejam não corresponde às evidências que temos das nossas capacidades humanas. Agentes são criaturas capazes de produzir ações eles mesmos; por isso, não há possível esperar que o agente desempenhe um papel sui generis na produção de sua ação, pelo menos não no sentido de uma intervenção do agente, como CA esperaria. Na verdade, o papel que o agente desempenha na produção de sua ação não é nada além de seus estados mentais (ou seus realizadores físicos) desempenhando um papel de certo tipo na produção de ação.

Foi argumentado que uma ação é essencialmente produzida por seu agente. Isso é explicado pelos estados mentais que contribuem causalmente para a produção da ação, que dependem de atividades cerebrais específicas que são características do agente. Assim, os estados mentais do agente são do agente em questão de maneira essencial. 
O problema do DA surge da concepção de agentes da CA em que esse teria um papel especial na produção de ação, que não poderia ser reduzido ao papel causal de um de seus estados mentais na produção causal da ação. Essa preocupação é supostamente justificada na teoria, pelo menos parcialmente, pela nossa experiência fenomênica de agir. No entanto, se a nossa concepção de agentes for mais modesta e de acordo com a evidência que temos de nossas capacidades humanas, então é possível perceber que o papel do agente em sua ação é desempenhado por seus estados mentais (ou seus realizadores físicos) quando esses contribuem causalmente para a produção da ação; pois é desse modo que as evidências até o presente momento sugerem que seres humanos podem produzir ações.

Os estados mentais (ou seus realizadores físicos) que desempenham um papel causal na produção da ação estão relacionados às atividades cerebrais do agente, o que ocorre na rede neuronal específica do agente e que exibe seu próprio padrão de atividade (como foi argumentado na discussão sobre a plasticidade do cérebro). Portanto, a produção causal da ação remonta especificamente ao seu agente, e deixa claro que essa produção em particular é caracteristicamente sua produção da ação em questão. O problema do DA não surge nesse contexto conceitual, porque a produção da ação pelo agente é, em si, uma expressão do agente, tendo em vista que a atividade do cérebro envolvida nela foi desenvolvida com base nas suas experiências, habilidades e preferências. 


\section{CONCLUSÃO}

O problema do Desaparecimento do Agente (DA) surge de certa concepção do agente; i.e., da concepção de agente proposta pela teoria da Causalidade do Agente (CA). Isso ocorre porque essa teoria espera que agentes humanos tenham certa capacidade de iniciar suas ações, o que seria uma capacidade irredutível, ou, pelo menos, a teoria sugere que o agente seria um tipo de gerenciador de seus processos de produção de ações, sendo capaz de revisá-los, e cuja capacidade não seria redutível a processos físicos.

A presente investigação dedicou-se a mostrar que essa concepção de agente defendida pela CA, e que dá um lugar de destaque para a consciência na produção das ações, não parece condizer com as recentes descobertas empíricas a respeito da produção das ações humanas. E, ao contrário da CA, a Teoria Causal da Ação (TCA) não necessariamente enfrenta as dificuldades trazidas por essa dissonância com as descobertas da neurociência, pois a TCA não requer que agentes humanos sejam concebidos da mesma maneira que a $\mathrm{CA}$ requer e, por fim, a TCA não depende dessa concepção como a CA depende.

Os estados mentais do agente participam causalmente da produção de suas ações, mas isso não quer dizer que o agente esteja excluído dessa produção. Afinal, não é meramente acidental que os estados mentais em questão sejam estados mentais do agente em questão, pois eles dependem da genética, do desenvolvimento, e das experiências do agente, dentre outros fatores caracteristicamente seus. Assim, quando uma explicação de ações afirma que estados mentais do agente causaram sua ação, há razões para crermos que essa ação não seja uma ação essencialmente do agente, produzida de uma maneira que lhe é característica.

Por essa razão, não é correto afirmar que o agente desapareceu dessa explicação de sua ação. Eu acredito que apenas alguém que esteja sob o domínio de uma concepção específica de agentes (como a concepção da CA) poderia afirmar que o agente desaparece numa explicação de ação que faça referência aos estados mentais do agente como sendo a causa de sua ação.

Nesse sentido, foi argumentado que é necessário revisar a concepção de agente na Filosofia da Ação, de modo que a concepção não esteja em conflito com o desenvolvimento do conhecimento empírico que temos a respeito das ações humanas. A nova concepção de agente proposta nesta investigação está em desacordo com a CA, mas casa bem com a TCA; por isso, a última deve ser preferida. 


\section{REFERÊNCIAS}

ANSCOMBE, E. Intentions. Cambridge: Harvard University Press, 1957.

BAYNE, T. Phenomenology and the feeling of doing: Wegner on the conscious will. In: POCKETT, S.; BANKS, W. P.; GALLAGER, S. (Ed.), Does consciousness cause behavior? Cambridge: The MIT Press, 2006. p. 169-185.

BAARS, B. A cognitive theory of consciousness. New York: Cambridge University Press, 1988.

BAARS, B.; GAGE, $\mathrm{N}$ (Ed.). Cognition, brain, and consciousness: introduction to cognitive neuroscience. Burlington: Elsevier, 2010.

BRATMAn, M. Two faces of intention. The Philosophical Review, Durham, v. 93, n. 3, p. 375-405, 1984.

1999. Intentions, plans and practical reasoning. The David Hume Series: Philosophy and Cognitive Science Reissues. Stanford: CSLI Publications

Two problems about human agency. Proceedings of the Aristotelian Society, v. 101, n. 1, p. 309-326, 2001.

CHISHOLM, R. Human freedom and the self. Lindley Lectures. Lawrence: University of Kansas Press, 1964.

. Person and object: a metaphysical study. London: G. Allen \& Unwin, 1976.

Comments and replies. Philosophia, v. 7, n. 3-4, p. 597-636, 1978.

CLARKE, R. Agent causation. In: O'CONNOR, T; SANDIS, C. (Ed.). A companion to the philosophy of action. Oxford: Wiley-Blackwell, 2010. p. 2018-226.

COHEN, M.; CAVANAGH, P.; CHUN, M.; NAKAYAMA, K. The attentional requirements of consciousness. Trends in Cognitive Science, v. 16, n. 8, p. 411-417, 2012. 
DAVIDSON, D. Actions, reasons and causes. The Journal of Philosophy, v. 60, n. 23, p. 685-700, 1963.

Essays on actions and events. Oxford: Clarendon Press, 1980.

DEHAENE, S.; CHANGEUX, J. P. ; NACCACHE, L. ; SACKUR, J. ; SERGENT, C. Conscious, preconscious, and subliminal processing: a testable taxonomy. Trends in Cognitive Science, v. 10, n. 5, p. 204-211, 2006.

DELGADO, J. M. Physical control of the mind: towards a psychocivilized society. New York: Harper and Row, 1969.

FISCHER, J. M. The metaphysics of free will. Cambridge: Blackwell Publishers, 1994.

FREUND, J.; BRANDMAIER, A. M.; LEWWJOHANN, L.; KIRSTE, I.; KRITZLER, M.; KRÜGER, A.; SACHSER, N.; LINDENBERGER, U.; KEMPERMANN, G. Emergence of individuality in genetically identical mice. Science, v. 340, n. 6133, p. 756-759, 2013.

GAZZANIGA, M. (Ed.). The cognitive neuroscience. Cambridge: The MIT Press, 2009.

HERRMANN, C. S.; PAUEN, M.; MIN, B.; BUSCH, N. A.; RIEGER, J. W. Analysis of a choice-reaction task yields a new interpretation of Libet's experiments. International Journal of Psychophysiology, v. 67, n. 2, p. 151-157, 2008.

HORNSBY, J. Agency and alienation. In: DE CARO, M.; MACARTHUR, E. D (Ed.). Naturalism in question. Cambridge, Mass.: Harvard University Press, 2004. p. 173-187.

JO, H.; HINTERBERGER, T.; WITTMANN, M.; BORGHARDT, T. L.; SCHMIDT, S. Spontaneous EEG fluctuations determine the readiness potential: is preconscious brain activation a preparation process to move? Experimental Brain Research, v. 231, n. 4, p. 495-500, 2013.

JUDISCH, N. Bringing things about. In: HAZLETT, A (Ed.). New waves in metaphysics. Basingstoke, NH: Palgrave Macmillan, 2010. p. 91-110.

KIM. J. The non-reductivist's troubles with mental causation. In: HEIL, J.; MELE, A (Ed.). Mental causation. Oxford: Oxford University Press, 1993. p. 189-210. 
LEWIS, D. Causation as influence. In: COLlinS, J.; HALL, N.; PAUL L. A. (Ed.). Causation and counterfactuals. Cambridge: The MIT Press, 2004. p. 75-106.

LIBET, B.; GLEASON, C. A.; WRIGHT, E. W.; PEARL, D. K. Time of conscious intention to act in relation to onset of cerebral activity (readiness-potential): The unconscious initiation of a freely voluntary act. Brain, v. 106, n. 3, p. 623-642, 1983.

Unconscious cerebral initiative and the role of conscious will in voluntary action. The Behavioral and Brain Sciences, v. 8, n. 4, p. 529-566, 1985.

LOWE, E. J. Personal agency: the metaphysics of mind and action. Oxford: Oxford University Press, 2008.

MAGUIRE, E., GARDIAN, D. G.; JOHNSRUDE, I. S.; GOOD, C. D.; ASHBURNER, J.; FRACKOWIAK, R. S. J.; FRITH, C. D. Navigation-related structural change in the hippocampi of taxi drivers. Proceedings of the National Academy of Sciences, v. 97, n. 8, p. 4398-4403, 2000.

MARQUES, B. S. Different kinds of decisions and an experiment on unconscious generation of free decisions: a conceptual analysis. Filosofia Unisinos, v. 16, n. 1, p. 44-57, 2015.

MELDEN, A. L'action libre. In: NEUBERG, M. (Ed.). Théorie de l'action: textes majeurs de la philosophie analytique de l'action. Liège: Mardaga, [1961]1991. p. 35-60.

MELE, A. Irrationality: an essay on akrasia, self-deception and self-control. New York: Oxford University Press, 1987.

Springs of action: understanding intentional behavior. New York: Oxford University Press, 1992.

Motivation and agency. Oxford: Oxford University Press, 2003.

Effective intentions: the power of conscious will. Oxford: Oxford University Press, 2009.

METZINGER, T. Inferences are just folk psychology. Behavioral and Brain Sciences, v. 27, n. 5, p. 670, 2004. 
MILLER, M.; DONOVAN, C. L.; VAN HORN, J. D.; GERMAN, E.; SOKOL-HESSNER, P.; WOLFORD, G. L. Unique and persistent individual patterns of brain activity across different memory retrieval tasks. Neuroimage, v. 48, n. 3, p. 625-635, 2010.

NAGEL, T. The view from nowhere. New York: Oxford University Press, 1986.

NAHMIAS, E. When consciousness matters: a critical review of Daniel Wegner's the illusion of conscious will. Philosophical Psychology, v. 15, n. 4, p. 527-541, 2002.

NIDA-RÜMELIN, M. Doing and subject causation. Erkenntnis, v. 67, n. 2, p. 255-272, 2007.

O'CONNOR, T. Agent causation. In: O'CONNOR, T. (Ed.). Agents, causes, and events: essays on indeterminism and free will. New York: Oxford University Press, 1995. p. 173200.

Press, 2000.

Persons and causes: the metaphysics of freewill. New York: Oxford University Agent causal power. In: RUSSELL, P.; DEERY, O. (Ed.). The philosophy of free will. Oxford: Oxford University Press, 2013. p. 229-250.

O'SHAUGHNESSY, B. The will. In: GUTTENPLAN, S. (Ed.). A Companion to the philosophy of mind. Oxford, Blackwell Publishers, 1996. p. 610-17.

PEREBOOM, D. The disappearing agent objection to event-causal libertarianism. Philosophical Studies, v. 169, n 1, p. 59-69, 2014.

RICOEUR, P. Oneself as another. Tradução de Kathleen Blamey. Chicago: University of Chicago Press, 1992. Original em francês Soi-même comme un autre, [1990]. Paris: Éditions Seuil.

SCHLEGEL, A.; ALEXANDER, P.; SINNOTT-ARMSTRONG, W.; ROSKIES, A.; TSE P. U.; WHEATLEY, T. Barking up the wrong free: readiness potentials reflect processes independent of conscious will. Experimental Brain Research, v. 229, n. 3, p. 329-35, 2013.

SCHROETER, F. Endorsement and autonomous agency. Philosophy and Phenomenological Research, v. 69, n. 3, p. 633-659, 2004. 
SCHRURGER, A.; SITT, J. D.; DEHAENE, S. An accumulator model for spontaneous neural activity prior to self-initiated movement. Proceedings of the National Academy of Sciences, v. 109, n. 42, p. E2904-13, 2012.

SERGENT, C.; BAILLET, S., DEHAENE, S. Timing of the brain events underlying access to consciousness during the attentional blink. Nature Neuroscience, v. 8, n. 10, p. 1391-1400, 2005 .

STEWARD, H. A metaphysics for freedom. Oxford: Oxford University Press, 2012.

TREISMAN, A. Theoretical and psychological perspectives. GAZZANIGA, M. (Ed.). The cognitive neurosciences. $4^{\text {th }}$ ed. Cambridge: The MIT Press, [2000] 2009. p. 199-200.

TREVENA, J.; MILLER, J. Brain preparation before a voluntary action: evidence against unconscious movement initiation. Consciousness and Cognition, v. 19, n. 1, p. 447-456, 2010 .

VELLEMAN, D. What happens when someone acts. Mind, v. 101, n. 403, p. 461-481, 1992.

WEGNER, D. The illusion of conscious will. Cambridge: MIT Press, 2002.

WEGNER, D. Self is magic. In: BAER, J.; KAUFMAN, J. C.; BAUMEISTER, R. F. (Ed.). Are we free? Psychology and free will. New York: Oxford University Press, 2008. p. 227247.

YOUNG, M. The short- and long-term consequences of believing an illusion. Behavioral and Brain Sciences, v. 27, n. 5, p. 677-678, 2004. 